Portland State University

PDXScholar

1990

\title{
Terrain disturbances by winter roads in the lower and central Mackenzie River Valley, N.W.T., Canada
}

Christoph Gnieser

Portland State University

Follow this and additional works at: https://pdxscholar.library.pdx.edu/open_access_etds

Part of the Geography Commons

Let us know how access to this document benefits you.

\section{Recommended Citation}

Gnieser, Christoph, "Terrain disturbances by winter roads in the lower and central Mackenzie River Valley, N.W.T., Canada" (1990). Dissertations and Theses. Paper 4165.

https://doi.org/10.15760/etd.6037

This Thesis is brought to you for free and open access. It has been accepted for inclusion in Dissertations and Theses by an authorized administrator of PDXScholar. Please contact us if we can make this document more accessible: pdxscholar@pdx.edu. 
AN ABSTRACT OF THE THESIS OF Christoph Gnieser for the Master of Science in Geography presented August 8, 1990.

Title: Terrain Disturbances by Winter Roads in the Lower and Central Mackenzie River Valley, N.W.T., Canada.

APPROVED BY THE MEMBERS OF THE THESIS COMMITTEE:
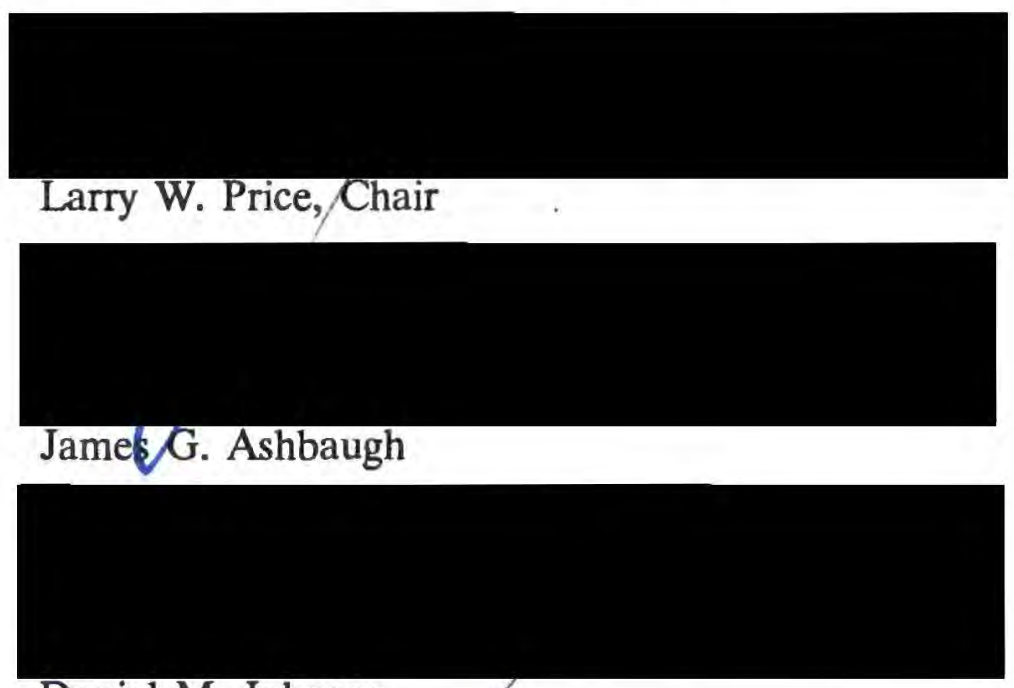

Daniel M. Johnson

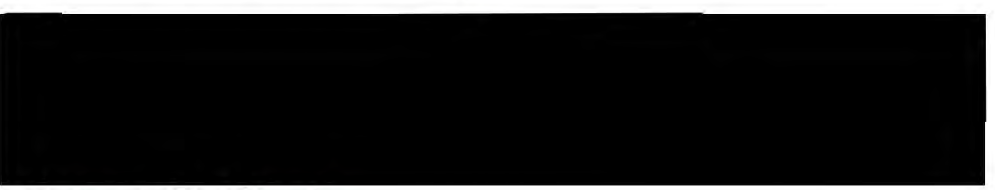

Robert O. Tinnin

Winter roads, built from compacted snow and / or ice, are common throughout the circumpolar North. They are considered effective and economical means of providing seasonal access into permafrost terrain while minimizing the potential for environmental damage. 
The purpose of this study is an appraisal of long-term environmental impacts of winter roads by comparative assessment of terrain morphology, microclimate, permafrost, soils, and vegetation, on winter road right-of-ways and in adjacent undisturbed control areas.

Terrain disturbances result primarily from the removal and deterioration of the vegetation and the organic mat. Associated changes in the ground thermal regime, i.e. increased soil temperatures, lead to the degradation of nearsurface permafrost. Increases in seasonal thaw depth, and thermokarst subsidence in supersaturated fine-textured substrates, are more substantial than has previously been reported from temporary winter road test sites in the Mackenzie River Valley. Observations on terrain morphology at abandoned right-of-ways indicate that terrain modifications are enduring, yet confined to the area of initial impact.

Plant communities adjust to continual disturbance with regard to their floristic composition. Winter road right-of-ways are vegetated by fewer species than adjacent control areas, reflecting a decreased abundance of shrubs and an increased dominance of few seed-producing species, primarily graminoids. Upland roadway sections exhibit notably reduced plant cover, even after recovery periods of more than 10 years, whereas lowland sites generally support vigorous 
plant growth.

Although surface perturbations by winter roads exceed disturbance levels predicted in previous studies, their overall impact on the terrain is smaller than disturbances caused by conventional all-weather roads. Wet lowland areas are less sensitive to winter road operations than dry upland sites and should be preferred for route selection. However, the success of winter roads in reducing terrain damage is closely tied to their proper preparation and maintenance, and the prudent observance of operation schedules. 
TERRAIN DISTURBANCES BY WINTER ROADS IN THE LOWER AND CENTRAL MACKENZIE RIVER VALLEY, N.W.T, CANADA

by

CHRISTOPH GNIESER

A thesis submitted in partial fulfillment of the requirements for the degree of

MASTER OF SCIENCE in GEOGRAPHY

Portland State University

1990 
TO THE MEMORY OF MY FATHER 
TO THE OFFICE OF GRADUATE STUDIES:

The members of the Committee approve the thesis of Christoph Gnieser presented August 8, 1990.

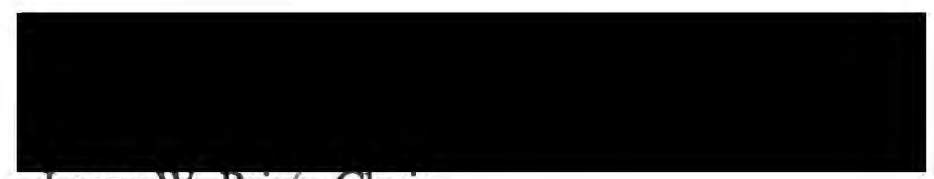

Larry W. Price, Chair
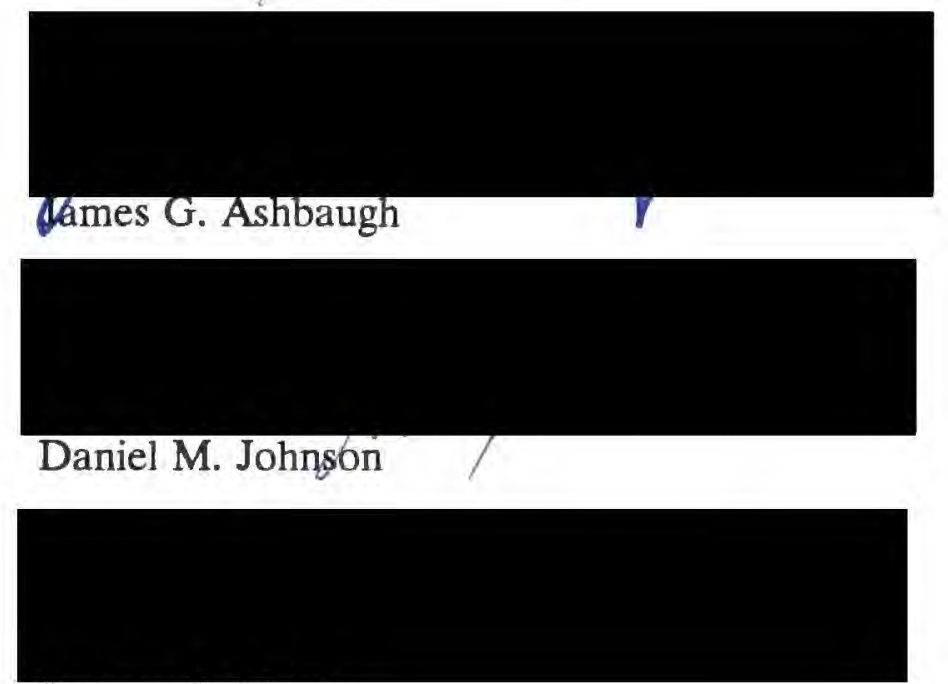

Robert O. Tinnin

\section{APPROVED:}

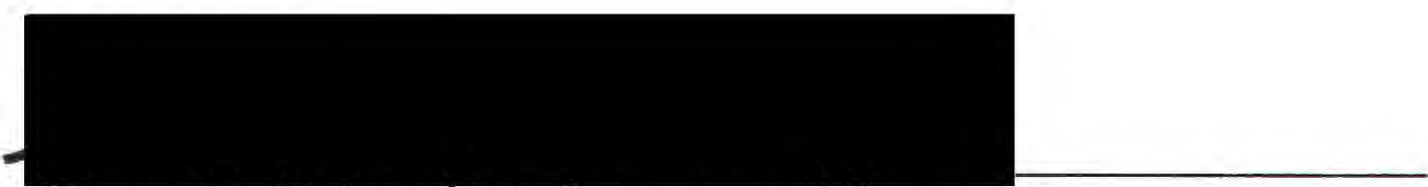

Thomas M. Poulsen, Chair, Department of Geography

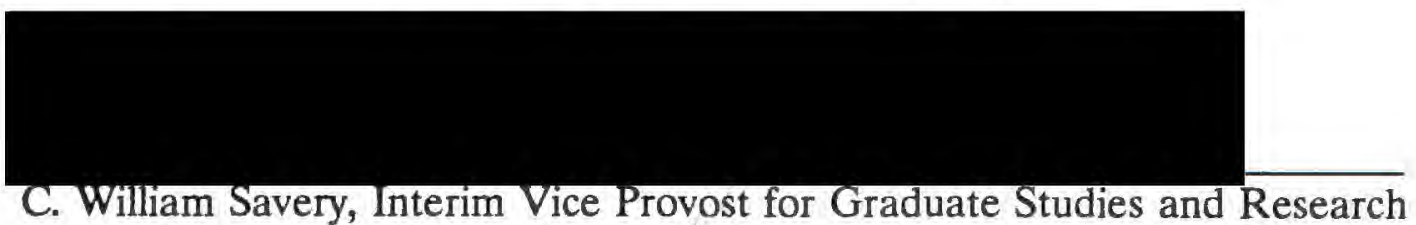




\section{ACKNOWLEDGEMENTS}

The realization of this research project involved the help of several individuals and institutions. I wish to acknowledge their efforts in bringing this thesis to fruition.

I am grateful to the Department of Geography, Portland State University, for generous endowments that relieved the financial burden of this research. I wish to extend thanks to Dr. Ross Wein and Bob Ellis who facilitated preparations in the field and made possible an extended visit to the Boreal Institute for Northern Studies. Extensive logistical support in the field was provided by the Inuvik Scientific Resource Center. Derek Johnson, Northern Forestry Centre, and Dr. George Argus, Museum of Natural Sciences, identified plant specimens.

I owe special thanks to my adviser Dr. Larry Price whose editorial expertise aided during the preparation of this thesis. Jennifer Selliken assisted with revisions during the final stages of writing.

I wish to express my love and gratitude to my family for their help and encouragement at all stages of what was, at times, an onerous task. I owe much to my sister, Dagmar Gnieser, who assisted competently during three months of field work, making the summer of 1989 a most memorable experience. 


\section{TABLE OF CONTENTS}

PAGE

ACKNOWLEDGEMENTS $\ldots \ldots \ldots \ldots \ldots \ldots \ldots \ldots \ldots$ iii

LIST OF TABLES. . . . . . . $\ldots \ldots \ldots \ldots \ldots \ldots \ldots$ viii

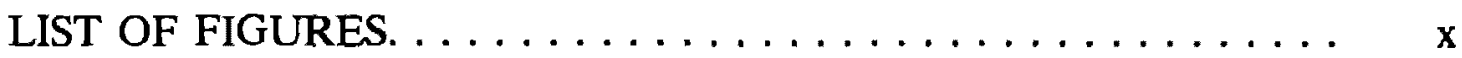

\section{CHAPTER}

INTRODUCTION. ................. 1

II

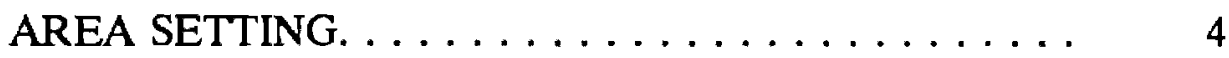

Physiography. ................ 4

Geology................... 6

Quaternary Glaciation. . . . . . . . . . . 6

Climate. . . . . . . . . . . . 8

Permafrost and Ground Ice Characteristics. . . . . . 11

Terrain Sensitivity. . . . . . . . . . . . . 14

Vegetation. .................... 14

Soils. ..................... 18 
PAGE

WINTER ROADS. . . . . . . . . . . . 20

Definition. ................... 20

Importance of Winter Roads. . . . . . . . . . 20

Environmental Protection: . . . . . . . . . . . 21

Route Selection. . . . . . . . . . . . . . 23

Right-Of-Way Clearing. . . . . . . . . . . . 25

Scheduling of Winter Roads. . . . . . . . . . . 27

Classification of Winter Roads. . . . . . . . . . 32

History of Winter Road Development

in the Study Area. . . . . . . . . . . . . 40

Winter Trails

CNT-Telephone-Line Corridor

Mackenzie Highway

Territorial Winter Roads on Ice

METHODOLOGY. ................

Field Sites. . . . . . . . . . . . . . . . 44

Measurements. . . . . . . . . . . . 45

Microclimate

Permafrost

Vegetation Sampling

Ground Subsidence

Soils 


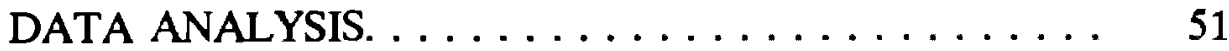

Changes in Microclimate. ............ 51

Solar Radiation

Surface Albedo

Soil Heat Flux

Surface and Air Temperatures

Soil Temperatures

Changes in Near-Surface Permafrost Characteristics. . . 63

Active Layer Depth

Ice Content

Ground Subsidence. . . . . . . . . . . . . 68

Soil Degradation. . . . . . . . . . . . . . 72

Botanical Characteristics and Revegetation on

Rights-Of-Way. . . . . . . . . . . . . . . . 79

VI TERRAIN DISTURBANCES - IMPLICATIONS TO

THE ENVIRONMENT. . . . . . . . . . . 88

Energy Budget Changes on Disturbed Terrain. . . . . 88

Permafrost Degradation. . . . . . . . . . . 91

Vegetation - Impact and Recovery. . . . . . . . . 94

VII SUMMARY AND CONCLUSIONS. . . . . . . 100

REFERENCES CITED. . . . . . . . . . . . . . . . . . . . . . . . 104 
APPENDICES

A TERRAIN SENSITIVITY AND SURFACE GEOLOGY IN THE LOWER AND CENTRAL MACKENZIE RIVER VALLEY. . . . . . . . . . 115

B VEGETATION-LANDFORM UNIT ASSOCIATIONS IN THE LOWER AND CENTRAL MACKENZIE RIVER VALLEY. . . 118

C SUMMARY OF STUDY SITE CHARACTERISTICS AND DISTURBANCE ACCOUNTS OF THE INVESTIGATED RIGHT-OF-WAYS. . . . . . . . . . .

D COVER ESTIMATES FOR VASCULAR AND NON-VASCULAR PLANTS ON THE INVESTIGATED RIGHT-OF-WAYS. . . . . . . . 134 


\section{LIST OF TABLES}

TABLE

PAGE

I Meteorological Data for Selected Stations in the Mackenzje

River Valley. . . . . . . . . . . . . . . . . 10

II Range of Climatic Criteria Required for Winter Road

Operations at Selected Locations in the Mackenzie

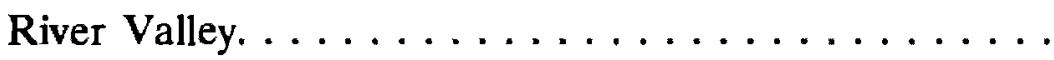

III Construction Program and Commercial Vehicle Movement on

the Canadian National Telecommunications Right-Of-

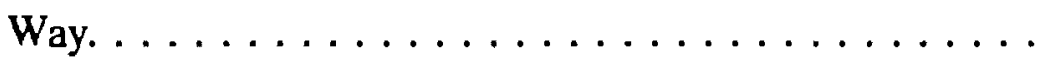

IV Mean Daily Differences in Air, Surface and Soil

Temperatures for Winter Roads and Control Sections. .

V Diurnal Soil Temperature Ranges on Winter Roads and

Control Sections. . . . . . . . . . . . . . 62

VI Mean Active Layer Thickness (M) on Roadway, Control

and the Road Shoulder............... 65

VII Ground Subsidence (CM) on Roadways......... 70

VIII Average Loss of Soil Material (CM) on Roadways. . . . . . 75 
IX Ground Cover (\%) of Vegetation Structure Classes on

Roadways (WR) and in the Adjacent

Control Sections $(\mathrm{CO}) \ldots \ldots \ldots \ldots \ldots \ldots \ldots$ 


\section{LIST OF FIGURES}

FIGURE

PAGE

1. Physiographic Regions of the Lower and Central Mackenzie

River Valley and Adjacent Areas. . . . . . . . . 5

2. Permafrost Characteristics at Selected Locations in the

Lower and Central Mackenzie River Valley. . . . . . . . 13

3. Forest and Tundra Regions of the Lower and Central

Mackenzie Rjver and Adjacent Areas. . . . . . . . 16

4. Probability of "N" or More Calendar Days of Winter Road

Use in any Winter at Various Locations in the

Mackenzie River Valley. . . . . . . . . . . . . 31

5. Solar Radiation Received at the Ground Surface. . . . . . . 53

6. Effects of Roadway Orientation on Irradiance. . . . . . . . . 54

7. Diurnal Range of Soil Heat Flux. . . . . . . . . 57

8. Active Layer Depths Across an Actively Used Roadway

Denuded of the Organic Mat and the Upper Mineral

Soil Layers. . . . . . . . . . . . . . . . 66

9. Ice Content in \% of Dry Weight at the Bottom of the

Active Layer. . . . . . . . . . . . . . . . . . . 69 
PAGE

10. Ground Subsidence on Right-Of-Ways. . . . . . . . 71

11. Soil Profiles. . . . . . . . . . . . . . 74

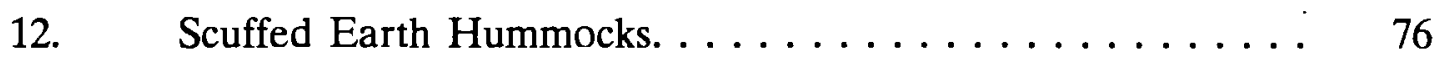

13. Surface Rutting. ................ 77

14. Unearthed Rocks on a Roadway Underlain by Coarse

Ground Moraine. ................. 78

15. Dominance of Grasses and Sedges on Roadways. . . . . . . 83

16. Tall Shrub Association on an Inclined, South-Facing Right-Of-Way. . . . . . . . . . . . . . . . 84

17. Encroachment of White Spruce (Picea glauca) and Mountain Avens (Dryas integrifolia) on a Right-Of-Way Across a Stabilized Colluvium Slope. . . . . . . . . . . 86

18. Roadway Illustrating the General Absence of Vegetation, particularly Shrubs, in the Track Areas after 10 Years of Abandonment. . . . . . . . . . . . . . 98 


\section{CHAPTER I}

\section{INTRODUCTION}

The acceleration of resource exploration and industrial development in Far Northwestern Canada during the past two decades has subjected permafrost environments to a broad range of human disturbances. The most widespread and extensive environmental perturbations result from myriad winter roads, seismic lines and drill pads crisscrossing the landscape. Winter roads, which include any kind of seasonally used trails over frozen, snow-covered terrain, or roads constructed from snow or ice, have been widely adopted as an economical means of providing access where low traffic volumes do not justify the construction and operation of conventional all-weather roads.

The principal objective of this research was to assess long-term environmental effects of winter road operation for a variety of surface types in Lower and Central Mackenzie River Valley, N.W.T., Canada. During summer 1989, nine study sites were established on winter-road-right-of-ways with varying disturbance histories between latitude $65^{\circ} \mathrm{N}$ and $68^{\circ} \mathrm{N}$. The field program was structured to monitor changes in terrain morphology, microclimate, permafrost characteristics, soils, and vegetation. Impact assessments were based on comparative monitoring of selected environmental parameters on winter road 
right-of-ways and representative undisturbed control areas. Given the almost complete lack of information on long-term disturbances on winter roads in Subarctic forests (Strang, 1973), and the extent of the study area over three degrees of latitude, the survey was, necessarily, of a reconnaissance nature, designed to provide a regional perspective. One of the purposes of the research was to provide information regarding the pattern, rate and potential for recovery of terrain, permafrost and vegetation with latitude. An additional goal was to determine if conclusions developed in the early 1970 s regarding the disturbance and recovery of winter-road-right-of-ways are still valid (Adam and Hernandez, 1977; Younkin and Hettinger, 1978).

The Mackenzie River Valley, hosting a broad range of tundra and taiga ecosystems, yields an excellent opportunity to study terrain response to winter road operation. Winter roads have been in operation in the area for nearly fifty years, and are, in places, readily accessible from the Mackenzie River. This presents a rare opportunity and made this study feasible in view of the current rigorous land use regulations that prohibit overland vehicle access to permafrostaffected areas during the summer. A wealth of baseline information exists on the area's physical and biological environment as a result of a comprehensive field research program initiated in response to the proposed Mackenzie Gas Pipeline during the early 1970s. In the context of this environmental impact assessment, winter road performance and adjunct short-term environmental 
effects were evaluated at a number of experimental test sites (Adam and Hernandez, 1977; Younkin and Hettinger, 1978). Although only concerned with the short-term impacts of winter road operation, these studies led to the wide adoption of winter roads as the most effective means of providing access to permafrost terrain while reducing the potential for environmental degradation. However, no detailed field studies have yet focused on the long-term effects of winter road operation on the environment.

In October 1989, the National Energy Board, Canada, sanctioned plans to export natural gas from the Mackenzie Delta - Beaufort Sea (Canadian Petroleum Association, 1990). Pipeline construction through the Mackenzie River Valley would inevitably require extensive snow and ice road operations as soon as 1996. Therefore, an urgent need arises to advance our understanding about the long-term environmental effects of winter roads. This is essential to allow more realistic appraisals of terrain sensitivity, and development of competent mitigation and reclamation measures to minimize terrain damage. 


\section{CHAPTER II}

\section{AREA SETTING}

\section{PHYSIOGRAPHY}

The Mackenzie River Valley, N.W.T., Canada, is a northwest trending lowland characterized by level to undulating, in places, hummocky landscape (Figure 1). The lower and central portions of the basin, between latitude $65^{\circ} \mathrm{N}$. and $68^{\circ}$ N., intersect two physiographic regions: 1) the Mackenzie Plain, a lowland separating the eastern ranges of the Mackenzie Mountains and the Franklin Mountains, and 2) the Anderson Plain, a narrow lowland belt adjacent to the Mackenzie River connected to a mosaic of broadly dissected upland plateaus (Bostock, 1965, 1970). Elevations in the basin range between $30 \mathrm{~m}$ a.s.l. near the Lower Mackenzie River and $150 \mathrm{~m}$ a.s.l. in the vicinity of Norman Wells; flanking mountain ridges attain elevations of 1,600 to $2.100 \mathrm{~m}$ in the Canyon Ranges and 700 to $1,000 \mathrm{~m}$ in the Norman Range. Slopes generally do not exceed 10 degrees, with the exception of cliffs adjacent to major drainageways and plateau escarpments in the Anderson Plain. 


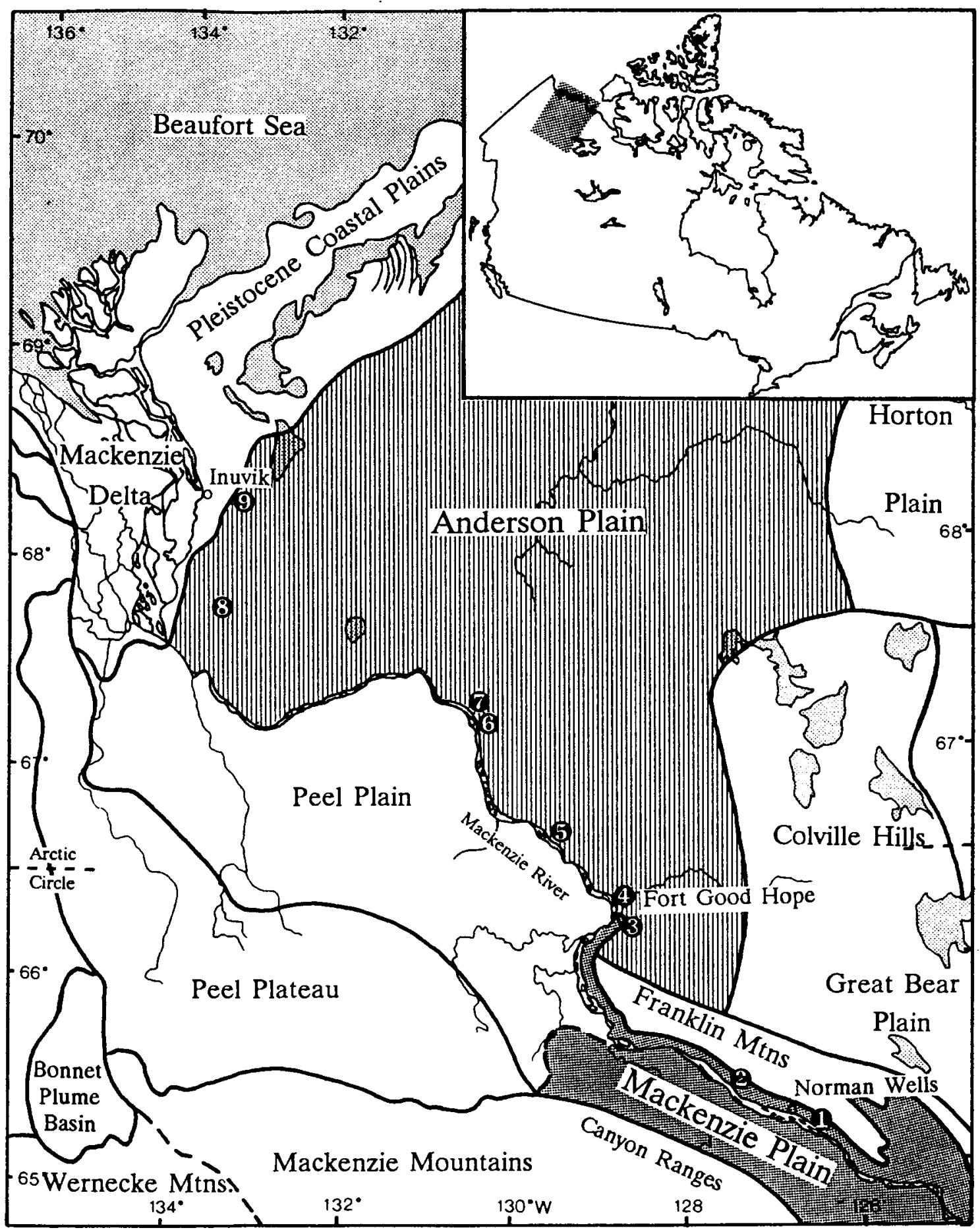

Figure 1. Physiographic regions of the Lower and Central Mackenzie River Valley and adjacent areas. Study sites are located by numbers (1-9). (Modified from Rowe, 1972.) 


\section{GEOLOGY}

The Mackenzie Plain and the flanking Franklin Mountains and Mackenzie Mountains are parts of the Eastern System of the Cordillera which is characterized by folded sedimentary bedrock. Dipping Devonian shales and limestones as well as sandstones of Lower Cretaceous occur intermittently along the Mackenzie River (Cook and Aitken, 1969). However, there is little bedrock control over the topography since the landscape has been profoundly modified by glacial phases in the Late Cenozoic. The Franklin Mountains, rising to the east of the Mackenzie Plain, are composed of folded and faulted Ordovician, Silurian and Devonian carbonate strata, primarily dolomites and limestones, with minor amounts of shale, sandstone and conglomerate (Douglas et al., 1976).

Lowland areas of the Anderson Plain are underlain by flat sedimentary rocks - south of $67^{\circ} 50^{\prime} \mathrm{N}$ primarily by Middle Devonian shales and siltstones, northwest of $67^{\circ} 50^{\prime} \mathrm{N}$ by Upper Devonian clay shales with interbedded layers of sandstone and argillite (Cook and Aitken, 1969). Upland plateaus are capped by resistant strata, e.g. Mid-Devonian limestone and Lower Cretaceous sandstone.

\section{QUATERNARY GLACIATION}

The Mackenzie River Valley was glaciated at least twice by Laurentide ice sheets (Hughes, 1972). Late Wisconsin ice covered the entire area and 
penetrated into the east-lying mountain fronts, reaching elevations of $1,525 \mathrm{~m}$ in the Canyon Ranges and $975 \mathrm{~m}$ at the south end of Richardson Mountains (Figure 1) (Hughes et al., 1983). Ice-marginal channels, terminal moraines, glaciofluvial and postglacial lacustrine deposits denote the maximum extent oflaurentide ice. Deglaciation history remains poorly charted. Ice retreat commenced along the eastern flanks of the Cordillera by 12,000 yr B.P. (Mathews, 1980; White et al., 1985). However, subsequent readvances of the ice are evidenced by lobate morainal systems and ice-marginal features within the maximum Laurentide limit (Hughes et al., 1989). Mackay and Mathews (1973) provide a minimum date for final deglaciation on the Mackenzie Plain near Fort Good Hope of $11,530 \pm 170$ yr B.P.

Ground moraine is ubiquitous throughout the area; rolling to hummocky terminal moraines occur locally. The tills are variable in texture, but typically of a clayey-silt matrix with 5 to $10 \%$ coarse fraction (Hughes et al., 1973). Till deposits up to $10 \mathrm{~m}$ in thickness are common, in places exceeding $30 \mathrm{~m}$ (Polar Gas Ltd., 1984). With retreat of the Laurentide ice sheet, glacial lakes occupied much of the study area (Hughes et al., 1973). Glaciolacustrine sediments exhibit a textural gradation from clay and silt strata of up to $50 \mathrm{~m}$ thickness to veneers of sand and fine gravel usually less than $6 \mathrm{~m}$ thick. After drainage of the glacial lakes, eolian processes locally reworked the tills, glaciofluvial and glaciolacustrine sediments. Terrace and floodplain deposits developed adjacent to present-day 
water-courses. Scree slopes formed along bedrock outcrops. Organic deposits developed in shallow depressions and on gentle slopes, and continue to thicken and spread at present (Hughes et al., 1973) (Appendix A).

\section{CLIMATE}

The Lower and Central Mackenzie River Valley falls within a Continental Subarctic climatic regime (humid microthermal (Dfc) of the Köppen - Geiger System). Summers are mild but short, winters are intensely cold and long. From December through March, relatively calm Arctic air predominates. Cyclonic breaks in the persistent high pressure system are rare, although protruding Pacific air occasionally produces major blizzards. Spring is characterized by an increase in cyclonic activity and the penetration of maritime air. During summer these moist air masses become progressively unstable due to surface heating. Cyclonic activity peaks in July and August with cyclogenesis and thunderstorm development common in the area of Norman Wells. In September, dropping surface temperatures stabilize the air masses, cyclonic activity gradually decreases and maritime air penetrates less frequently.

Beginning in November, high pressure systems travel southeastward through the Mackenzie River Valley, and by December Arctic air once again dominates the entire region. 
Climatic data for the Lower and Central Mackenzie River Valley are available from three reporting stations: Norman Wells, Fort Good Hope and Inuvik (Table I). Temperatures decrease with latitude as expected; across the basin, temperatures are significantly warmer in the lee of the Canyon Ranges and the Richardson Mountains than east of the Mackenzie River. Mean annual temperatures vary from $-6.3^{\circ} \mathrm{C}$ at Norman Wells to $-9.6^{\circ} \mathrm{C}$ at Inuvik, with January and July mean daily temperatures ranging from $-27.5^{\circ} \mathrm{C}$ to $16.1^{\circ} \mathrm{C}$ in the south and $-29.0^{\circ} \mathrm{C}$ to $13.2^{\circ} \mathrm{C}$ in the north, respectively. Degree-day values above $5^{\circ} \mathrm{C}$ decrease from 1020 at Norman Wells to 650 at Inuvik (Atmospheric Environment Service, 1982). Annual frost-free periods range from 126 days to 50 days, respectively (Burns, 1973). Air flow in the Mackenzie River Valley basically follows the river north during the summer and south during the winter, but is considerably modified by local topography, large water bodies and the movement of synoptic disturbances. Precipitation, estimated from evaporation and run-off regimes, ranges from about $317 \mathrm{~mm}$ in the north to about $500 \mathrm{~mm}$ in the south (Burns, 1973). Rainfall peaks between April and July, but is common until November. Snow constitutes about $60 \%$ of the total annual precipitation range at Inuvik, but less than $45 \%$ at Norman Wells. Mean maximum snow cover depths range from $40 \mathrm{~cm}$ near the Arctic Coast to $75 \mathrm{~cm}$ at Norman Wells and in the lowlands adjacent to the Mackenzie River (Potter, 1965). 


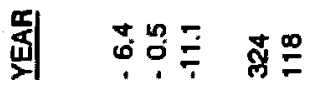

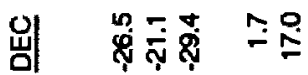

회 으ำ

히

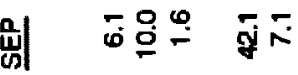

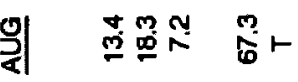

켸

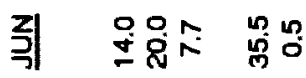

홀

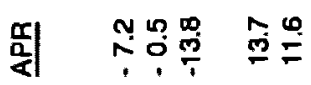

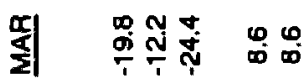

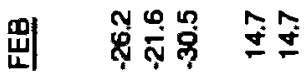

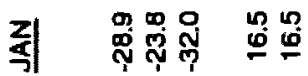

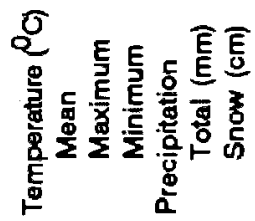

ำำำ

ชุำำำ

ชชำ

เับำ

픙ㅇㅇ 잉

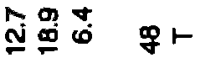

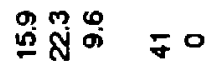

幽哭

ஸึ่

ชั

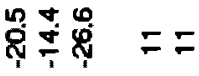

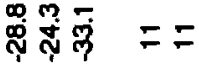

으ำ品号 =

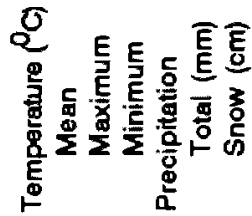

兽早导

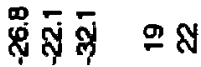

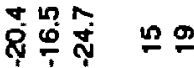

읶

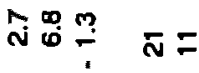

옹ํำ

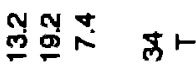

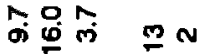

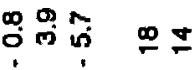

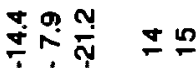

웡ํํ윰 =

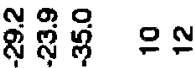

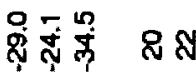

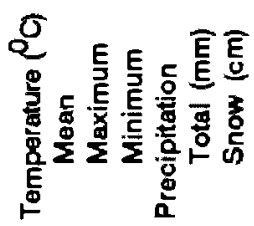

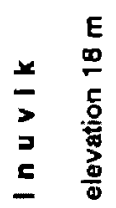

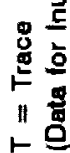

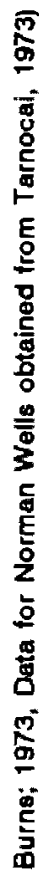

톤

옹

8

is 


\section{PERMAFROST AND GROUND ICE CHARACTERISTICS}

Information on the post-glacial paleoecology of the Mackenzie River Valley allows a speculative chronosequential reconstruction of permafrost development in the area. Palyonological records and radiocarbon dates on peat samples indicate a somewhat warmer and drier climate before 8,000 yrs B.P. (Ritchie, 1984). A subsequent transition to moister conditions is indicated by the rapid regional accumulation of peat deposits between 8,000 and 3,000 yrs B.P. The increased development of peat plateaus between 4,000 and 3,000 yrs B.P. evidence the subsequent spreading of permafrost (Zoltai and Tarnocai, 1975). Modern climatic conditions prevailed by 3,000 yrs B.P. with only short-term oscillatory fluctuations (MacDonald, 1987). Air temperature records and data obtained from deep borehole temperature profiles indicate an increase in mean annual ground temperatures of $3^{\circ} \mathrm{C}$ from the late 1800 s to the 1940 s, with a decrease of about $1{ }^{\circ} \mathrm{C}$ into the mid-1970s (Mackay, 1975). However, decadal temperature records for the 1980 s evidence a mean increase of air temperatures by approximately $0.9^{\circ} \mathrm{C}$ in Western Canada (Berry, unpublished data). A continuation of such a warming trend in the context of global warming would result in the partial or complete degradation of warm and relict permafrost in the Mackenzie basin.

At present, permafrost is discontinuous but widespread in the southern portion of the study area, while it is continuous in the northern reaches 
(Figure 2) (Brown, 1970). The aerial extent of permafrost and ground ice contents increase with latitude (Heginbottom et al., 1978). However, site characteristics, especially soil texture, surface drainage, slope and aspect, vegetation and surface disturbance, have a considerable influence (Heginbottom and Kurfurst, 1977). Ice contents in soils and sediments increase with decreasing particle size and attain highest values in organic soils and peat (Lau and Lawrence, 1977). Visible ice, commonly in the form of finely-defined minute crystals, is the most frequently recorded type of ground ice. Origin and history of surface deposits are primary factors in controlling the occurrence, form and allocation of ground ice (Hughes, 1972b). Ground ice occurs throughout the till plains as thin irregular seams yet comprises less than $25 \%$ by volume in the upper 2 to 3 meters of the deposit. In drumlinoid and hummocky moraine till, excess ice commonly occurs in thin lenses in the uppermost 2 to $3 \mathrm{~m}$, with large erratically distributed bodies of segregated ice at greater depth (Hughes et al., 1973). Glaciolacustrine deposits exhibit varying ground ice contents relative to their textural composition. Sand typically has pore ice only and may, if well drained, lack any ice. Silt and varved clay deposits contain pore- and segregated ice as tabular lenses several centimeters to $1 \mathrm{~m}$ or more thick. Unbedded clays may hold up to $40 \%$ and more of segregated ice by volume, often enclosing unfrozen material. 


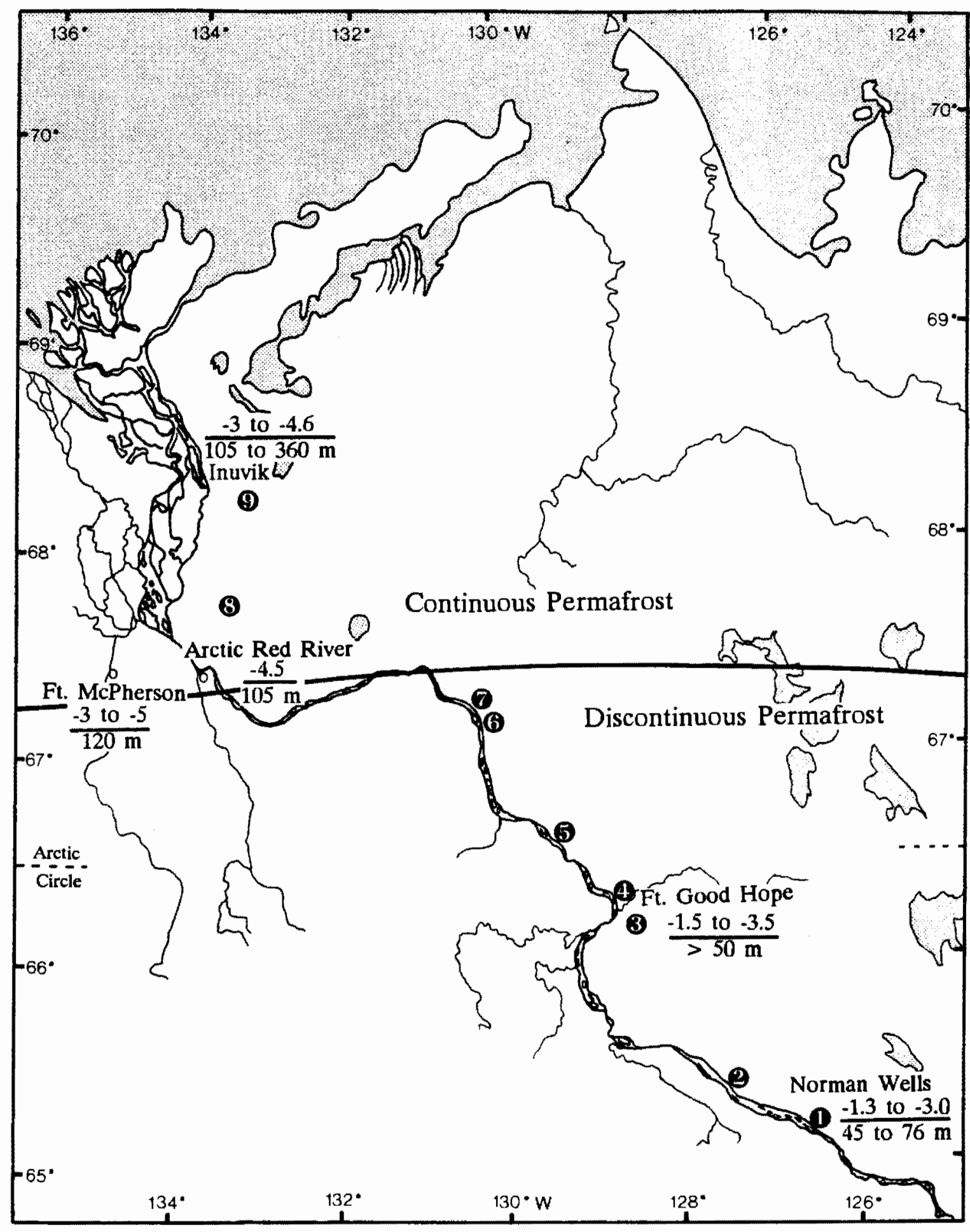

Figure 2. Permafrost characteristics at selected locations in the Lower and Central Mackenzie River Valley. Numbers above the line indicate mean annual ground temperatures at the depth of zero amplitude with a possible variation of $1.5^{\circ} \mathrm{C}$. Numbers below the line depict approximate permafrost depths (Data compiled from Brown [1967, 1970, 1978] and Mackay [1967, 1975].) 
Recent alluvium and glaciofluvial deposits, found along rivers and streams usually have deep active layers or remain unfrozen (taliks), whereas fossil floodplain deposits (particularly those of low energy streams) and terraces exhibit relatively high ground ice contents (Mackay, 1966). Organic terrain or peatlands are perennially frozen, with a very restricted active layer; exceptions are areas beneath lakes, ponds and fenlands which thaw to depths of several meters (Hughes et al., 1973). Organic soils and peat may seasonally exhibit extremely high water contents and considerable quantities of segregation ice. Ice contents commonly average $75 \%$ by total volume, however, moisture levels in the surface layers are depleted to less than $10 \%$ during the summer (Zoltai and Pettapiece, 1973a).

\section{TERRAIN SENSITIVITY}

Terrain susceptibility to disturbance in the Mackenzie Basin increases with latitude as a result of progressively increasing ground ice contents in surface deposits. However, on a smaller scale, terrain sensitivity varies considerably with type and character of surface deposits (Appendix A).

\section{VEGETATION}

The vegetation of the Lower and Central Mackenzie Valley changes with latitude from Boreal Forest to Forest-Tundra (Rowe, 1972). The increasing 
severity of environmental conditions from south to north, is reflected by a decrease in species diversity and productivity, and an increased reliance on vegetatively propagating species (Figure 3) (Hernandez, 1974). Plant cover is complete throughout the study area except for areas of intense frost action, recent fires, slumps and slides, man-made disturbances, water bodies and bedrock exposures. Vegetation types of the Mackenzie River Valley have been classified and mapped by the Forest Management Institute (1972, 1974, 1975) and Reid (1974) (Appendix B). The same principal plant communities occur throughout the lower and central reaches of the valley, yet the extent of each type varies with latitude (Hernandez, 1974).

Soils underlain by near-surface permafrost are commonly dominated by black spruce (Picea mariana) with an admixture of tamarack (Larix laricina) in immature stands. Localized well drained soils support white spruce (Picea glauca), white birch (Betula papyrifera), poplar (Populus balsamifera) and aspen (Populus tremuloides), of which all but spruce are important secondary species after fire and other disturbances. High shrubs include dwarf birch (Betula glandulosa), willow (Salix spp.) and alder (Alnus spp.), the latter of which are important species in early succession on disturbed areas or recent alluvium. Common dwarf shrubs are Labrador tea (Ledum spp.), bog blueberry (Vaccinium uliginosum), lingonberry (V. vitis-idaea), bearberry (Arctostaphylos uva-ursi) and red-fruit bearberry ( $A$. rubra), prickly rose (Rosa acicularis), 


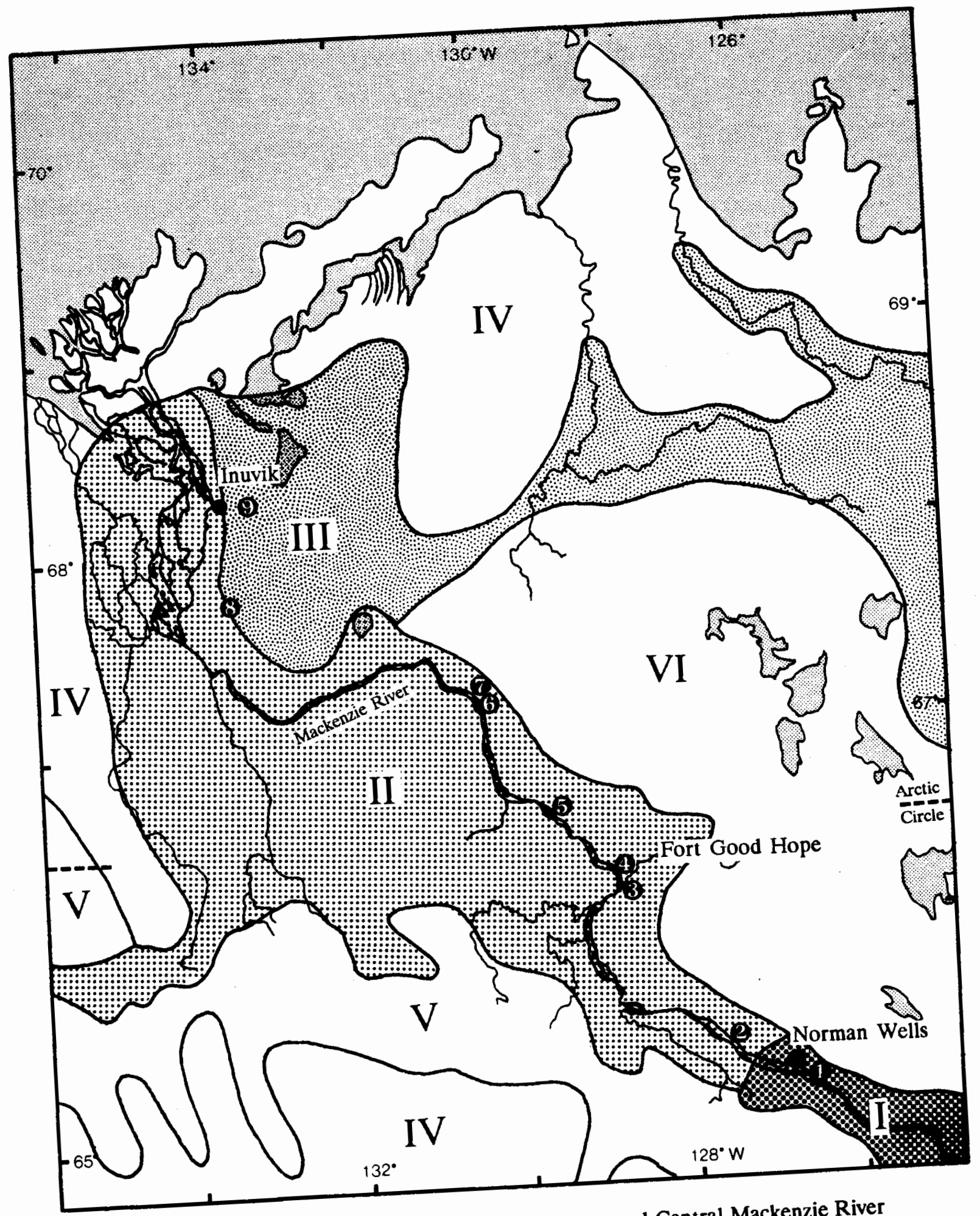

Figure 3. Forest and tundra regions of the Lower and Central Mackenzie River Valley and adjacent areas. I: Upper Mackenzie, I. Lowe Forest-Tundra, VI: Forest-Tundra, IV: Alpine and Arctic Tundra,
Northwest Transition (Modified from Rowe, 1972.) 
soapberry (Sheperdia canadensis), crowberry (Empetrum nigrum), and various species of cinquefoils (Potentilla spp.). Ground cover varies with micro-site. Dry sites are dominated by feathermosses (Hylocomium sp., Pleurozium sp., Dicranum sp.) and lichens (including species of Cladina, Cladonia, Cetraria, Peltigera and others), while wet sites usually support peat mosses (Sphagnum spp.) and ericaceous dwarf shrubs. Imperfectly drained depressional areas or seepage runs exhibit an increased abundance of sedges (Carex spp.) and cottongrass (Eriophorum spp.).

In the vicinity of Norman Wells, fairly productive, closed-canopy coniferous forests prevail, with admixtures of deciduous hardwoods and high shrubs in early seral communities (Figure 3 -- Upper Mackenzie Section). To the north (Figure 3 -- Lower Mackenzie Section), restricted root penetration due to near-surface permafrost, short growing seasons and low soil temperatures inhibit the uptake and cycling of nutrients (Hardy Associates, 1980). Black spruce, a species tolerant of shallow active layers, is the dominant tree species growing stunted and forming thickets and woodlands with a low shrub association. Tree density is often deceptively high due to vegetative reproduction leading to layered growth. Well-drained sites exhibit fairly productive stands of white spruce and poplar extending into the Mackenzie Delta (Ritchie, 1984). In the northern expanse of the study area, climatic severity is the apparent over-riding environmental factor (Figure 3 -. Forest- 
Tundra) (Rowe, 1972). Lowlands east and south of Inuvik are characterized by open woodlands of black spruce with a codominant low shrub and moss understory.

\section{SOILS}

Soils in the Lower and Central Mackenzie River Valley have been described by Tarnocai (1973), Zoltai and Pettapiece (1973), Pettapiece (1974a, 1974b), Pettapiece and Zoltai (1974a), Brewer and Pawluk (1975). Soil classification in the following discussion is according to "The Canadian System of Soil Classification" (Agriculture Canada Expert Committee on Soil Survey, 1987); equivalents of the U.S. system are provided in parenthesis.

The Cryosolic order (Pergelic subgroups) dominates the area (Tarnocai, 1973). Turbic cryosols (Pergelic Ruptic subgroups) are characteristic of fineand medium-textured soil materials. Markedly affected by cryoturbation, they commonly exhibit the formation of earth hummocks. These average 1 to $1.5 \mathrm{~m}$ in diameter and possess a microrelief of 30 to $40 \mathrm{~cm}$ between mound crest and hollow (Pettapiece and Zoltai, 1974). Associated cyclic soil bodies commonly exhibit cryogenic dispersion or intrusion of mineral and organic matter and soil profile disruption in horizontal and vertical direction. Roughly $80 \%$ of the land surface comprised by mineral soils in the Lower Mackenzie Valley displays a hummocky microrelief (Zoltai and Tarnocai, 1974). Static Cryosols (Pergelic 
subgroups) are frequently associated with coarse-textured, well drained deposits veneered by a thick organic mat. Organic Cryosols (Pergelic Histosols or Pergelic Histic subgroups of other orders) are predominantly found in ombrotrophic wetlands in association with peat plateaus and palsas.

Soils unaffected by permafrost occur in "pockets" throughout the study area. Low-lying margins of streams and lakes and unfrozen fen wetlands are frequently characterized by gleysols (Aqu-suborders) and organic soils (mainly Fibrists and Mesisols) (U.S.: Fibrists and Hemists) where the accumulation of organic material exceeds $40 \mathrm{~cm}$ (Pettapiece and Zoltai, 1974). Small proportions of Eutric and Dystric Brunisols (Cryochrepts or Eutrochrept and Dystrochrept) occur on well drained terrain; they characteristically exhibit podzolic or luvisolic (Alfisol) features with eluviated surface horizons and subsurface accumulations of Fe, Al, organic matter or clays (Pettapiece and Zoltai, 1974). Orthic and Cumulic Regosols (Entisols) are associated primarily with recent alluvium and colluvium on slopes subject to mass wasting. 
CHAPTER III

WINTER ROADS

\section{DEFINITION}

Winter road refers to any kind of seasonally used vehicle trail over snowcovered terrain or a road constructed from snow, ice or a mixture of both. Winter road operations may be temporary where access is limited to a single winter season, or perennial where a right-of-way is used continually for numerous winter seasons. The period for which a winter road remains functional is related to its structural and physical properties which protect the underlying surface (Adam, 1981). Specific kinds of winter roads include: winter trails, compacted snow roads, processed snow roads, manufactured snow roads, ice-capped snow roads and solid ice roads; a detailed discussion is presented later.

\section{IMPORTANCE OF WINTER ROADS}

Winter roads are common throughout the circumpolar North. Snow and ice roads are effective means of providing access in permafrost regions, while reducing the necessity of gravel and land resources, and conserving energy (Keyes, 1976). Perennial snow or ice roads (operated for consecutive winters) 
render economically feasible low traffic volumes which do not justify the construction and operation of conventional year-round roads.

Winter roads furnish the exclusive means of overland transportation in much of Siberia (Harris, 1986). In the Canadian Subarctic numerous outlying settlements and mining camps depend on the supply of bulky and low-value freight by winter hauling. Winter roads lend themselves well to temporary applications, such as seismic exploration and construction activities in sensitive terrain or timber hauling in the Boreal Forest (Adam, 1978).

\section{ENVIRONMENTAL PROTECTION}

The sensitivity of permafrost terrain to surface perturbations requires restriction of overland travel to when the ground is frozen and a snowpack of adequate depth has accumulated. Access into tundra and taiga is facilitated during winter because the frozen terrain provides a firm surface for vehicular movement and trails can be cleared more easily. Moreover, winter allows the utilization of frozen lakes and rivers for travel, thereby avoiding impacts on the land.

The concept of using snow and ice roads for the protection of terrain evolved fairly recently (Johnson and Collins, 1980). Prior to the early 1970s neither Alaskan nor Canadian authorities had established regulations to protect Tundra and Taiga environments from surface perturbations. In the course of 
extensive hydrocarbon exploration on the Alaskan and Western Canadian Arctic Coastal Plains, caterpillar tractors and other tracked vehicles travelled over thawed ground in the summer, the effects of which have been well documented (Everett et al., 1985; Hok, 1969; Hernandez, 1973; Kerfoot, 1972; Lawson, 1986; Radforth, 1972; Radforth, 1973; Walker et al., 1987). Winter roads served as economical alternatives to all-weather roads, allowing the operation of nonspecialized wheeled and tracked vehicles. Through the 1950 s winter trails were often bladed to the mineral soil (Walker et al., 1987); road surface preparation was more a means to improve the trafficability of the route than to protect the ground surface.

Concern over vehicle-induced disturbances in Arctic and Subarctic arose in the late 1960s (Johnson and Collins, 1980). Recognizing that the overall impact by vehicular movement over frozen, snow-covered ground is considerably less than comparable activities on thawed terrain, Alaskan and Canadian authorities prohibited summer travel across permafrost terrain unless adequate measures for its protection were taken, such as the use of low-ground pressure vehicles. In the early 1970 s, research into winter road performance and adjunct short-term environmental impacts led to the adoption of winter roads as the most effective means of reducing damage to vegetation and permafrost (Adam and Hernandez, 1977; Younkin and Hettinger, 1978). Subsequently, regulations for the prevention of excessive terrain perturbations by winter road use were 
established. Route selection, winter road preparation and maintenance schemes as well as working equipment are commonly stipulated in land use permits; their observance is reinforced by regular winter road inspections (Christofferson, Interview, 1989).

\section{ROUTE SELECTION}

Environmental protection commences with initial route selection. The projected use of the route influences design criteria such as width, grades, cross slopes and alignment (Keyes, 1976). A particular road lay-out will, in most cases, be controlled by terrain topography, soil conditions, drainage patterns, and wildlife habitat.

The performance of critical areas along a winter road ultimately determines its functionality. Terrain underlain by frost-susceptible, ice-rich soils should be avoided owing to its sensitivity to slides or slumps, excessive thaw settlement, and soil creep (Lotspeich, 1974). Potentially weak spots may be identified from topographic or surface geology maps and aerial photographs. However, the suitability of a route can only be confirmed by prudent soil, thermal and ground ice reconnaissance. Winter roads frequently require rerouting or bypassing of road sections where terrain reactions exceed anticipated disturbance levels or where slopes are too long or too steep. Sloping terrain and approaches to stream crossings with ice-rich soils are potentially the 
most acute problem areas (Adam, 1974). Cross slopes in excess of $5 \%$ should be bypassed since winter road operation will require surface grading using "cut and fill" practices. Grades steeper than $12 \%$ commonly impede the operation of conventional wheeled vehicles, and surface rutting as a consequence of spinning wheels is inevitable (Keyes, 1976). Lotspeich (1974) advises to break long steady grades with short sections of level or reverse grades. Thereby, the potential for erosion is reduced by preventing the accumulation of excess drainage water on the right-of-way. Downwind slopes are often preferable due to greater snow accumulation (Adam, 1978). Stream crossings are commonly established where gently sloping banks allow easy passage to the ice bridge. Stream bank stability and susceptibility to erosion are important criteria to be considered.

Lowland soils with a peraquic moisture regime freeze to form a solid substrate and, thus, compact less than peat covered upland soils (Wein and Bliss, 1971). However, in early winter frost penetration into these soils is slow. The frozen surface of lakes and rivers may be optimal for the routing of winter roads in terms of construction costs and the prevention of terrain disturbances. Yet, late freezeup may locally delay preparatory work on the winter road. 


\section{RIGHT-OF-WAY CLEARING}

The importance of right-of-way clearing depends on terrain conditions, the type of winter road being constructed and the nature of the existing vegetation (Hardy Associates, 1984). Carelessness in clearing a right-of-way, particularly on supersaturated icy soils and on river banks, may result in surface deterioration and, hence, thermal and hydraulic erosion, slope failure and stream siltation (Pipeline Application Assessment Group, 1974). Thus, clearing procedures, schedules, the necessary vehicular equipment and clearing widths are stipulated by the authorized land use agencies in the Northwest Territories.

Vegetation clearing can commence as soon as sufficient snow and frost penetration into the ground permit the operation of bulldozers. Tracked equipment is selected according to the type and height of the vegetation; the Environmental Protection Service (1976) recommends that working equipment should not exert a ground pressure in excess of $55 \mathrm{kN} / \mathrm{m}^{2}(8 \mathrm{psi})$. Clearing of an open spruce forest at the Northern treeline may be accomplished with a small crawler tractor, such as a D5 Caterpillar. However, in a dense stand of mature spruce in the Boreal Forest a heavy tractor, such as a D9 caterpillar, may be required. The operation of underpowered bulldozers can contribute to terrain degradation by the slippage of the cleated tracks when forward motion is impeded by a large tree or a group of trees (Inter-Disciplinary Systems Ltd., 1973). Trees and high shrubs are commonly felled by "high-blading", that is, 
knocking the vegetation over with the blade held slightly above the surface. Ground vegetation and low shrubs are bent over and compressed under the weight of the equipment and, thereby, to some extent preserved. Yet, the vegetative surface suffers where scarce snow cover provides little protection from the tracks, or where branches, twigs, or leaves of evergreen shrubs break under the compressional forces of passing vehicles.

Clearing should preferably be carried out in late winter at temperatures below $-18^{\circ} \mathrm{C}$, when all roots are anchored in the frozen ground and trees and high shrubs break above their stump when being pushed over (Inter-Disciplinary Systems Ltd., 1973). In early winter when frost penetration into the soil is insufficient, trees may be uprooted causing the organic layer to rip. It is imperative to preserve the ground vegetation and the organic mat which insulate the underlying frozen ground and guard against erosive processes.

Machine-cleared rights-of-way are commonly grubbed and cleaned up by hand since remaining tree stumps and debris would be hazardous to rubber tired vehicles. The slash is wind-rowed at the corridor margins and compacted by bulldozer to accelerate decay. However, windrowing of slash is controversial; freshly cut trees and shrubs provide prime breeding materials for bark-beetles and wood borers, and windrows represent a fire hazard (Hardy Associates, 1984). Alternative methods for the disposal of clearing debris such as woodchipping, scattering or controlled burning may be specified in the land use 
permit.

Sensitive slopes with potentially unstable soils or high ground-ice content and approaches to water crossings may require hand-clearing and / or reduced clearing widths to prevent excessive surface disturbance (Pipeline Application Assessment Group, 1974). Hand-cleared corridors exhibit a higher rate of plant survival, less compaction of the organic mat and the soil, and smaller increases in thaw depth than land cleared by crawler tractor. However, the advantages of hand-clearing a right-of-way are lost if it is subjected to further disturbance from winter road operation (Adam and Hernandez, 1977).

\section{SCHEDULING OF WINTER ROADS}

Alaskan and Canadian land use agencies stipulate winter road schedules according to ice (snow) and weather conditions along the right-of-way. Accumulative snow depth, Degree-day values above or below $0^{\circ} \mathrm{C}$ or depth of frost penetration into the substrate, respectively, have been established as decisive climatic criteria. The Alyeska Pipeline Service Company has appended snow density as a design criterion for their snow work pads, since this will ultimately determine the roads' load-bearing capacity and durability (Johnson and Collins, 1980).

Appreciable terrain disturbance can occur in early winter if snow and frost conditions are not suitable for winter road operation (Pipeline Application 
Assessment Group, 1974). Hence, the Environmental Protection Service (1976) recommends delaying construction until $13 \mathrm{~cm}$ of snow have accumulated and the ground is frozen to a depth of at least $20 \mathrm{~cm}$. The winter road season ends when the road surface looses its load-carrying capacity and terrain damage may ensue. Heat absorption of a darkened snow or ice road surface is increased due to a lower albedo, and snowmelt and runoff from the surface commonly occur before the undisturbed snowpack adjacent to the road starts to thaw (Adam, 1974). Likewise, melting at the ground surface-snow (ice) interface starts earlier on roadways than in the adjacent surface owing to higher heat transfer and attenuation coefficients of artificially compacted snow or ice.

The seasonal limits for winter road use can be approximated on the basis of historic temperature and snowfall records. Table II presents the range of climatic criteria required for winter road operations (Kosten, 1976). The specifications are guidelines only since the local variability of terrain conditions requires actual decisions to be based on field observations.

Adam (1974) evaluated theoretically available winter road periods in the Mackenzie River Valley by determining the joint probability of snow depths and accumulated Degree-days of frost at particular dates in the fall, and accumulated Degree-days of thaw (adjusted for radiation and road albedo) in spring. $\mathrm{He}$ assumed $20 \mathrm{~cm}$ of snowfall and 550 Degree-days of frost before winter road construction could commence in early winter and $1.3 \mathrm{~cm}$ of accumulated thaw on 


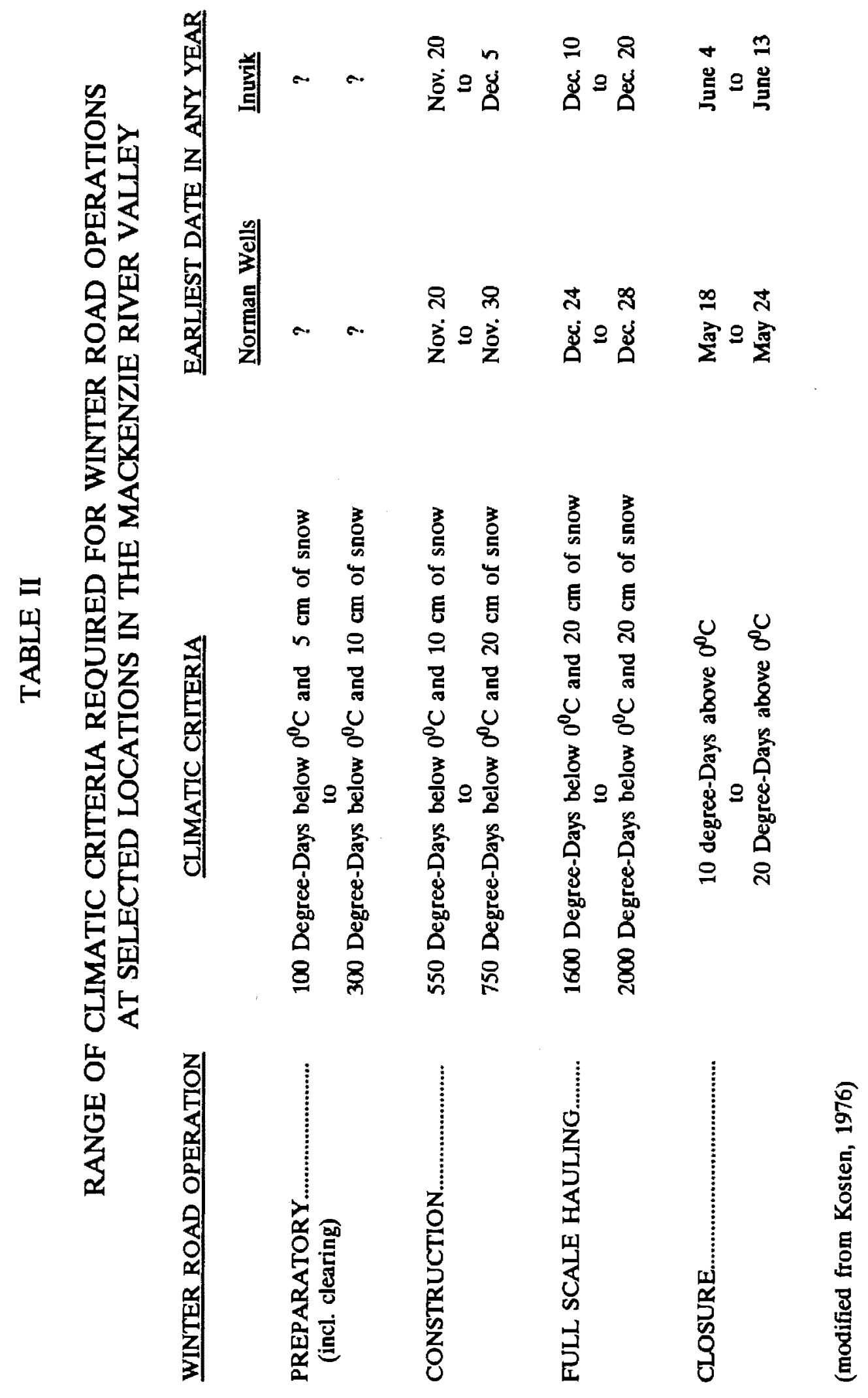


consecutive days, a value which was found to represent a daily mean temperature of $0^{\circ} \mathrm{C}$, for the shut-down of winter roads (Figure 4). The period available for winter road operation is, however, significantly shorter since road construction has to be accomplished within this time interval and several days are usually lost during early winter and late spring due to unseasonal thaws. Between 1982/83 and 1988/89 the compacted snow road linking Norman Wells and Ft. Norman in the Central Mackenzie River Valley was operated on an average of 77 days as compared to a minimum of 120 days theoretically available in any year (Figure 4).

Construction of public winter roads in the Central Mackenzie River Valley is commonly begun no later than December 15 to open the roadways to traffic by January 1 . March 20 is the official closing date unless climatic conditions permit longer use. Although snow conditions might prohibit travel during the day, night temperatures below freezing may allow limited hauling and extend the final shut-down date (Hardy Associates, 1984).

After the official closing date, N. W. T. land use permits require the removal of snow fills, drainage control structures and ice bridges prior to breakup. Since roadbed failure has frequently occurred, the remaining snow cover provides little protection to the underlying ground surface from crawler tractors and heavy 4-wheel drive pickups used during the "clean-up". Surface rutting, soil compaction and crushing of the ground vegetation could to some extent be avoided if winter road closure was expedited. 


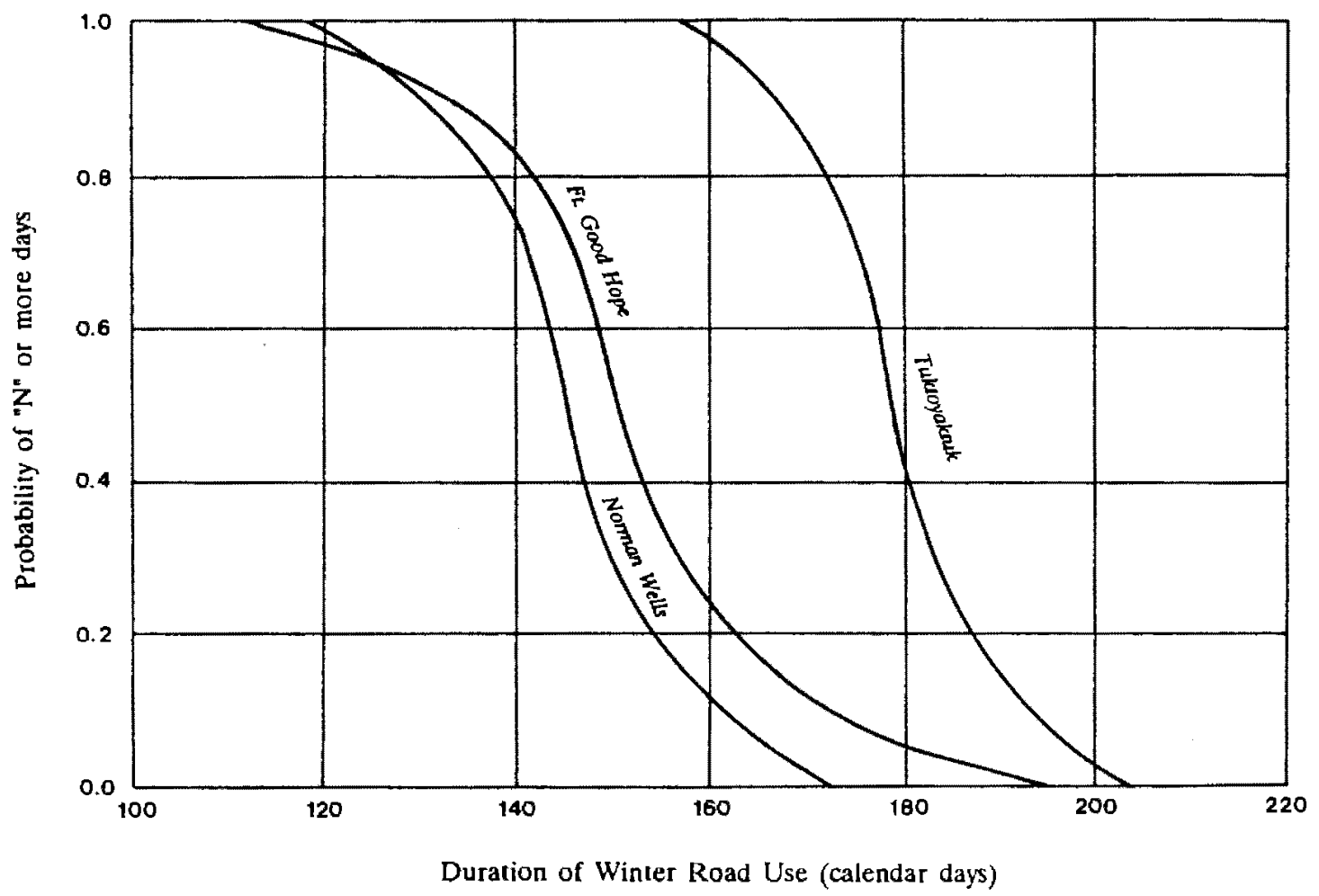

Figure 4. Probability of " $\mathrm{N}$ " or more calendar days of winter road use in any winter at various locations in the Mackenzie River Valley, (Modified from Adam, 1974.) 


\section{CLASSIFICATION OF WINTER ROADS}

Winter roads can be distinguished on the basis of road surface characteristics. Strength and durability of snow- and ice road surfaces are determined by the type and properties of the construction material as well as processing techniques and equipment used. The extent of road surface preparation depends on the required density and hardness of the snow or ice surface to support the types of vehicles using it, anticipated traffic volumes and loads (wheel loads) and to provide adequate protection to the underlying ground surface. A standardization of construction and maintenance programs for the various types of winter roads is difficult owing to the variability of weather conditions and terrain characteristics. Nevertheless, the Alyeska Pipeline Service Company has advanced engineering specifications for five types of snow pads on the basis of vehicle types and loads (Johnson and Collins, 1980). Adam (1978) differentiates between winter roads on ice and ice bridges, winter trails, snow roads and ice roads, which may either be used temporarily or perennially. His classification follows.

Winter roads on ice and ice bridges are prepared rights-of-way on the frozen surface of lakes and streams. The ice thickness is usually increased by clearing the snow off the surface, thereby removing the insulative cover and allowing increased frost penetration. Construction and maintenance costs are low and environmental disturbances are avoided unless the ice thickens too 
much so that aquatic lifeforms are threatened or streamflow is impeded.

Winter trails are relatively unimproved rights-of-way, established by a single pass of a tracked or low-ground-pressure wheeled vehicle over snow-covered terrain. Surface preparation is confined to the compaction of the snow by repeated passes of crawler tractors. Where less specialized vehicles are operated on the right-of-way, the snow is commonly "back-bladed" to fill hollows and depressions in the trail. Light drags may be used to level and compact the surface. Subsequently, the trail is allowed to sinter and gain strength through "age-hardening". The physical principles underlying this process are water vapor pressure gradients in the snow inducing the growth of necks between snow grains through sublimation (Ramseier and Keeler, 1966). Low temperatures favor the hardening of snow. The most rapid increase in strength occurs during the first two or three days of "age-hardening" (Adam and Hernandez, 1977). However, construction schedules rarely permit sintering intervals of more than 24 hours.

Maintenance efforts on winter trails are generally confined to keeping the surface covered with snow to delay thawing in the spring. Surface deterioration is inherent where wheeled vehicles with high tire pressures are used. Compared to snow or ice roads, winter trails provide the least environmental protection and should, therefore, be used exclusively by low ground-pressure, tracked or "balloon-tired" vehicles (Adam, 1978). 
Compacted snow roads are built with snow as a cut and fill material to establish a relatively smooth surface. Prior to construction, early snowfalls are compacted by light, tracked vehicles to induce frost penetration to sufficient depths. Once $20 \mathrm{~cm}$ of snow accumulate and the active layer is frozen sufficiently to support heavy construction equipment, bulldozers shape the snow into a road grade. The surface is levelled by backblading or light log drags and compacted by repeated passes of a crawler tractor.

Snow road applications require snow densities of at least $0.55 \mathrm{~g} / \mathrm{cm}^{3}$ to accommodate wheeled vehicles (Adam, 1978), a value, which, in the Far North, can only be attained and exceeded by artificial densification through compaction. Heavy steel or log drags are necessary to apply enough pressure to ensure satisfactory compaction. The compressional forces exerted by drags or rollers on a snow cover cause individual snow grains and grain aggregates to break, resulting in a decreased average grain size and denser packing. Snow temperatures and moisture levels in the snow are important variables in compaction. For a given compactive effort, highest snow densities are achieved at temperatures slightly below $0^{\circ} \mathrm{C}$ (McClung, 1980), albeit packing of snow at $-40^{\circ} \mathrm{C}$ is virtually impossible (Christofferson, Interview, 1989).

Compacted snow roads are usually allowed to "age-harden" for at least 48 hours before full-scale operation (Adam et al., 1984). The importance of the "age-hardening process" is evidenced by U.S. Navy field experiments (Adam, 
1981), which indicate that the immediate operation of tracked and wheeled vehicles on dry, freshly compacted snow causes churning of the surface with no increase in compacted hardness over time. Since the entire snow column is compacted in one step, snow densities and hardness values decrease significantly from the road surface towards the base of the snow layer. Consequently, compacted snow roads have relatively low load-bearing capacities unless used by low-ground pressure vehicles. Low vehicle speeds and judicious routing across the gentlest possible slopes are essential to keep maintenance efforts down. Maintenance entails regular grading, compaction, the patching of potholes and ruts, and the reworking of the surface after snowfalls.

Processed snow roads are constructed from snow that has been "agitated" by means of harrows, snow plows or other specifically designed equipment prior to compaction. Thereby, the number of contact points among snow particles is increased and layers of snow of different temperatures and consistencies are mixed. As a result, greater densities are achieved during compaction and snow hardness values increase due to the ameliorated growth of bonds among the snow particles.

Alternatively, a roadbed may be constructed from individually compacted layers of snow, as opposed to one-step compaction of the entire snow column. In the Upper and Central Mackenzie River Valley public snow roads are constructed by "layered compaction", a technique providing the densest and most 
evenly compacted type of snow road (Adam, 1984). In early winter, the snow cover and vegetation along the right-of-way are compacted by low-ground pressure vehicles to accelerate frost penetration. As soon as sufficient loadbearing capacity is gained and about $30 \mathrm{~cm}$ of snow accumulate, crawler tractors (i.e. Caterpillar tractors D-5 to D-7) blade as much snow as possible to the sides of the roadway. Bulldozers are equipped with soft tracks, commonly known as "white pads", to minimize disturbances of the ground vegetation. Wedge- or mushroom-formed blade- or skid-shoes, fitted under the blade, are designed to raise its cutting edge above the ground to prevent the "scalping" or levelling of the surface layer. However, in terrain of marked microrelief the effectiveness of blade shoes is, yet, limited and the scuffing of hummocks and tussocks is inevitable (Linton, Interview, 1989). Organic material and soil mixed with a base layer of snow will cause maintenance problems in spring due to intensified thawing.

Frost penetration into the ground for at least one or two days is recommended before wheeled, motorized graders are permitted on the roadway to blade the snow back onto the roadway. Drags or rollers are used to compact each individual veneer of snow applied. The thickness of individual snow layers depends on the physical properties of the snow, ambient temperatures, and the type and weight of equipment used, but generally measure less than $5 \mathrm{~cm}$.

Following compaction, each top snow layer is allowed to sinter and gain strength 
through "age-hardening" before another veneer of snow is applied or the road is opened to traffic.

The road surface is maintained with motorized graders and drags, or rollers for compaction. Maintenance schedules depend on the types and loads of vehicles using the winter road, vehicle speeds, traffic volumes and atmospheric conditions. During storms new fallen snow is bladed off the roadway and subsequently reapplied in thin layers.

Land use regulations require a minimum compacted snow surface thickness of $5 \mathrm{~cm}$ for the operation of snow roads in the Mackenzie River Valley. Public winter roads, limited to regular highway type vehicles with gross loads of maximum $64,000 \mathrm{~kg}$, are maintained to allow travel at an average speed of at least 35 kilometers per hour. The snow roads linking Norman Wells with Ft. Good Hope and Ft. Norman, respectively, accommodate mainly pickups to heavy trucks (Lafferty, Letter, 1990).

Manufactured snow roads are built from artificial snow, which is commonly manufactured at a water source, hauled to the right-of-way and end-dumped into place. The construction scheme for manufactured snow roads does not differ from other snow roads. "Snow-making" becomes necessary where there is a lack of natural snow. During the construction of the Alyeska Pipeline sections of snow pads had to be built from manufactured snow when snowfalls in early winter were light and harvest sources, such as lakes or snow drifts adjacent to 
the right-of-way, were unavailable (Johnson and Collins, 1980).

Ice-capped snow roads are constructed where insufficient snow accumulates or where proper densities and hardness values cannot be attained. Water is sprayed on a compacted snow surface to bond snow particles and augment the strength of the road surface. The water is pumped out of perennially flowing streams or deep lakes into water trucks. According to Adam (1978), about $2.5 \mathrm{~cm}$ of water are required to adequately ice-cap a snow road, a value which can be translated into 250,000 liters needed per kilometer on a 10 $\mathrm{m}$ wide snow pavement. In hummocky terrain considerably larger volumes may be required to level the microrelief. The high costs of ice-capping (approximately Can\$ 3,000 per mile for a 4-month period in 1989) justify the implementation of water only when and where absolutely necessary (Christofferson, Interview, 1989). In the Mackenzie River Valley ice-capped snow roads are used for hauling of heavy equipment in the course of resource exploration activities or where roads have to be maintained beyond the official closing date.

Solid ice roads are constructed where the lack of snow prohibits other types of winter roads to be built or where heavy loads or high volumes of traffic require greater road surface strength than can be provided by snow roads. As opposed to ice-capped snow roads a base of snow is not required, yet, would be beneficial, especially in hummocky terrain with marked microrelief. Ice roads 
are built by sprinkling water onto the ground to fill depressions and form an ice surface. The first application of water wets the snow or ground to form a seal that prevents seepage. Subsequently, ice is built up in layers several cm thick, until the desired thickness and smoothness is attained.

Ice aggregate winter roads are built of crushed ice hauled to, and enddumped on the right-of-way. The aggregate ice is usually "mined" by fracturing or chipping ice from frozen lakes and rivers. Water is sprayed or hosed onto the aggregate to bond it. Due to the surface roughness of ice aggregate winter roads they have been shown to provide better traction than solid ice roads, while rendering comparable durability. Due to high construction costs this relatively new concept in winter road design has yet only been used for experimental purposes.

Ice as a construction material for overland winter roads significantly increases the road's stability and longevity (Christofferson, Interview, 1989). However, the limited availability of water during winter, concerns about the impacts of the withdrawal of water on lake or stream environments, and the exorbitant construction expenditures restrict the use of water in the construction of snow or ice roads. 


\section{HISTORY OF WINTER ROAD DEVELOPMENT IN THE STUDY AREA}

\section{$\underline{\text { Winter Trails }}$}

Winter access into the Mackenzie River Valley became necessary during World War II to allow the flow of equipment and supplies needed at Norman Wells, N.W.T., for the CANOL Pipeline Project of the U.S. Army. In the winter of 1942/43 two overland trails were cleared northwestward through the Upper Mackenzie Valley to Norman Wells, N.W.T. (Wonders, 1962). These winter roads allowed barging on the Mackenzie River to commence prior to the breakup on Great Bear Lake and enabled winter hauling of urgent items by "tractor train". However, after the initial year both trails were abandoned as the emergency passed and winter-hauling for civil purposes didn't pay.

During the late 1960s and early 1970s, thousands of kilometers of winter trails were cleared throughout the Mackenzie River Valley and the Mackenzie Delta for seismic exploration activities in the search for hydrocarbon resources. The number of trails cleared each year decreased after the territorial land use regulations came into effect in the early 1970s. Yet, in 1976/77 the movement and servicing of oil exploration rigs still required the construction of about $\mathbf{8 8 0}$ kilometers of winter roads, more than half of which were overland snow or icecapped snow roads (Adam, 1978). 


\section{CNT-Telephone-Line Corridor}

Between 1963 and 1965 Canadian National Telecommunication (CNT)

cleared a right-of-way for a telephone line to Inuvik, N.W.T, thereby opening the way for the operation of a winter road parallel to the Mackenzie River for its entire length. Until 1971 the trail was used for routine maintenance on the line and as a haul road by oil companies and seismic crews. From $1969 / 70$ to $1974 / 75$, a privately operated compacted snow road was constructed along the right-of-way with minor grade-reducing diversions and route improvements. The snow road was built only as far as the most northerly of destinations required that season. Construction was performed with bulldozers (Caterpillar D-6 through D-9) and motor graders (Caterpillar models 12 and 14). No snow making equipment or plow trucks were operated, but drags were used for road surface compaction (AVCON, 1976). The road was opened in early January when stream crossings were passable and closed in mid-April by removal of the ice bridges. Traffic volumes along the winter road are hard to estimate since only commercial vehicles passing the tollgate at Fort Simpson were recorded (Table III). Intermediate traffic movements north of Ft. Simpson are not known. In $1975 / 76$ the contractor's lease for building and operating the snow road expired. Since then, the road has been used irregularly by native trappers and hunters on snowmobiles and limited hauling by exploration crews. 
TABLE III

\section{CONSTRUCTION PROGRAM AND COMMERCIAL VEHICLE MOVEMENTS ON THE CANADIAN NATIONAL TELECOMMUNICATIONS RIGHT-OF-WAY}

\section{Year}

1969-70

$1970-71$

1971-72

$1972-73$

1973-74

1974-75
Construction Program

Fort Simpson to Wrigley

Fort Simpson to Norman Wells

Fort Simpson to Inuvik

Fort Simpson to Inuvik

Fort Simpson to Inuvik

Fort Simpson to Norman Wells
Commercial Vehicle Movement

?

1,483

1,441

1,207

574

- Two-way trafic passing the toll gate at Fort Simpson

(Source: AVCON Aviation Consultants Ltd., 1976).

\section{Mackenzie Highway}

During the winter of $1970 / 71$, a right-of-way was cleared for the longplanned Mackenzie Highway, a public all-weather road designed to provide access to the settlements on the eastern shore of the Mackenzie River and to foster resource development in the Valley and the Beaufort Sea. Construction was halted south of Wrigley, N.W.T., in 1975 when plans to develop the Mackenzie Valley as a pipeline and transportation corridor were suspended because of concerns about environmental disturbances and socioeconomic impacts on the native population (Berger, 1977). Until 1979 a snow road was constructed on the right-of-way for winter hauling from Wrigley, N.W.T., to Inuvik, N.W.T., when it became obsolete with the completion of the all-weather Dempster Highway. Since 1979, a processed snow road has been constructed 
annually on the right-of-way between Wrigley, N.W.T., and Norman Wells, N.W.T. In the winter of $1988 / 89$ the road was extended to Ft. Good Hope, N.W.T., after 10 years of abandonment.

\section{Territorial Winter Roads on Ice}

Public winter roads, linking Inuvik, N.W.T., with Aklavik, N.W.T., and Tuktoyaktuk, N.W.T., in the Mackenzie Delta, are constructed annually on frozen stream channels. South of the Delta, the construction of winter roads on the Mackenzie River is impeded by highly variable, treacherous ice conditions along the river as well as late freezeup and early breakup dates. 


\section{CHAPTER IV}

\section{METHODOLOGY}

\section{FIELD SITES}

Nine winter road research sites were established within the Lower and Central Mackenzie River Valley between latitude $65^{\circ} 13^{\prime} \mathrm{N}$ and $68^{\circ} 12^{\prime} \mathrm{N}$. Principal selection criterion for winter road sites was that initial disturbance dates (right-of-way clearing or winter road operation) had to be older than 15 years. The nine investigated sites included three winter road right-of-ways currently still in use (Site \# 1,2,3) and six abandoned winter road right-of-ways (Site \# 4, 5, 6, 8, 9) (Figure 1). Neither cumulative traffic volumes/loads nor the time span since discontinuation of use were considered as criteria during the initial right-of-way selection, since appropriate data are sketchy or unavailable.

Specific site locations were selected according to terrain sensitivity ratings obtained from disturbance susceptibility maps (Anonymous, 1975), and ease of access from the Mackenzie River as determined by aerial photography (Ripley, Klohn and Leonoff Alberta Ltd., 1970; Foothills Pipe Lines (Yukon) Ltd., 1979; Canadian Arctic Gas Pipeline Ltd., 1975). Study transects within each individual research site were established in diverse environmental settings with regard to botanical characteristics, morphology and geologic substrate. This was an effort, 
to provide information on terrain reactions of distinct landform units and vegetation associations. Winter road widths, course and slopes were surveyed and mapped on all nine study sites. Transects were marked in a permanent way to allow reevaluation in the future as long-term monitoring sites. Site characteristics and disturbance accounts are summarized in Appendix C.

\section{MEASUREMENTS}

All measurements are based on comparative monitoring of selected environmental parameters, discussed below, on disturbed winter road right-ofways and representative undisturbed control areas. The research sites were monitored successively during July and August 1989. Thus, observations on permafrost conditions and microclimate at the individual sites cannot be compared to one another. Whether or not the prevailing climatic conditions, at the time of this study, were a normal reflection of conditions for this area, was not considered.

\section{Microclimate}

Air and Soil Temperatures. Air and soil temperatures were measured on roadways and in the control area with Yellow Springs Instruments (YSI) No. 401 thermistors and recorded to $0.1^{\circ} \mathrm{C}$. All temperature probes were calibrated prior to and upon completion of the field work. Output from the sensors was recorded, via a custom-made switch-box, in the form of resistance data from a 
FLUKE 77 Multimeter and manually logged. The loss of information through the interposed switch-box was negligible and accuracy, resolution, and response time of the output device were higher than for the thermistors. Readings were taken hourly during daytime and at two-hour intervals from midnight to 8 a.m.

Air and surface temperatures were measured synchronously on the winter road right-of-way and in the control section at $0,0.1,0.5$ and $1.0 \mathrm{~m}$ above the ground surface. All sensors were shielded from direct irradiance. For surface temperature measurements the vinyl-coated thermistor beads were covered with surface materials; sensors measuring air temperature were encased in quadruplelayered, reflective sheet-aluminum radiation shields, but were subject only to natural ventilation. Thus, data values in excess of the actual temperatures were recorded under conditions of minimal convective exchange and cloudless sky, a common midday occurrence.

Soil temperatures were assessed at the same sites at depths of $0.05,0.1,0.25$ and $0.5 \mathrm{~m}$ or to active layer depth. Equipment constraints made the measurement of air and soil temperatures on consecutive days necessary; atmosphere-soil temperature profiles can, thus, not be related to one another.

Soil Heat Flux. Soil heat flux was measured directly with Thornthwaite soil heat flux discs, bearing a resolution of $9.6 \mathrm{Wm}^{-2}$. The soil heat flux systems were placed horizontally at a depth of $5 \mathrm{~cm}$ below the surface of the winter road right-of-way and the control. Output was synchronously recorded every 
hour during the day and at two-hour intervals between midnight and 8 a.m.

The discs' absolute accuracy depends on the factory-assigned calibration and on their insertion into the ground. The variability of the soil heat flux around a site was not possible to assess since only two systems were available. The failure of one of the soil heat flux discs during the field program required that measurements be obtained under comparable atmospheric conditions on consecutive days for control and winter road sections of the three northernmost research sites (Figure 1).

The validity of measurements obtained by using soil heat flux plates is questionable, especially in wet soils, because of possible coupling between heat conduction and mass moisture migration, including a thermally-induced capillary effect (Beattie et al., 1973). In addition, the plates may not have the same conductive capacity as the soil which could create a barrier to heat flow. Nevertheless, the results are useful to illustrate differences in the sensible heat flux between the disturbed environment and the control section.

Solar Radiation. Incoming solar radiation $\mathrm{K} \downarrow$ was measured with an EPPLEY (Black and White) Pyranometer at Sites \# 4, 6, 8 and 9. The sensor was placed at ground surface level in the control section and on the winter road right-of-way. The factory-assigned calibration was used after cross-checking against another EPPLEY system. Output could only be recorded at hourly intervals; readings were obtained from a FLUKE 77 Multimeter. 
reflected solar radiation. The pyranometer was mounted upright on a mast, 1.5 $\mathrm{m}$ above the ground surface or dense shrub canopy, and could be inverted for measurement of reflected solar radiation. Because radiation fluxes vary spatially in vegetation canopies, the instrument was moved to improve sampling.

\section{Permafrost}

Active Layer Depth. Frost table depths were determined by probing with an OAKFIELD Soil Sampler to a resistant layer. Three or four transects were established perpendicular to the winter road right-of-ways in distinct, visually recognized terrain units. At each study site, one of the transects intersected the microclimate plots on the disturbed surface area and in the control area. The transects penetrated 9 to $12 \mathrm{~m}$ into the control section on both sides of the winter road. Active layer depths were determined across the disturbed surface at 1.5 to $3-\mathrm{m}$ intervals, every 3 meters in the control. In areas of hummocky microrelief, frost table depths were probed in the inter-mound depressions.

It was assumed, that sufficient free water was present in the soil, so that the frost table depth would be indicated by an impermeable surface. The validity of this procedure is questionable, particularly if implemented in finegrained soils with a high specific surface area and an appreciable amount of unfrozen pore water at and just below $0^{\circ} \mathrm{C}$ (Mackay, 1977). Consequently, at the freezing level a gradational increase in penetration resistance may be experienced and, thus, probes may be pushed several decimeters below the 
active layer. The obvious implication is a significant overestimation of frost table depths by an amount which may vary with the observer and the diameter of the probe. However, since relative (not absolute) active layer depths were assessed for comparative analysis of perturbed and undisturbed sites with similar soil texture, the probing method rendered satisfactory results.

Ice Content of the Upper Portion of the Frost Table. Frozen soil material of the upper 10 centimeters below the frost table was obtained from the roadway and the control area with an OAKFIELD Soil Sampler (inner diameter $2 \mathrm{~cm}$ ). Sample sizes varied from 17 to $78 \mathrm{~g}$. The frozen samples were packaged in sealed aluminum tubes and plastic bags to inhibit evaporative loss. The samples were ovendried at $105^{\circ} \mathrm{C}$, and ice contents were determined on a per cent weight basis.

\section{Vegetation Sampling}

Floristic characteristics were assessed by sampling the transects which had previously been established for active layer depth measurements at diverse terrain units. Sample quadrates of $1 \mathrm{~m}^{2}$ were randomly located along the transects on the winter road and in the control area; an additional plot of the same dimension was located at the leading edge (transition) between winter road and control. Cover estimates were obtained in each quadrate sampled for individual vascular plant species, mosses, lichen, litter, dead moss, bare peat and exposed mineral soil or rock. Tree and shrub heights were approximated, their 
cover estimated separately on one plot of $100 \mathrm{~m}^{2}$, centered around the smaller $1 \mathrm{~m}^{2}$ plot. A list of species sampled in a total of 105 plots and related cover estimates are provided in Appendix D. Scientific nomenclature follows Porsild and Cody (1980).

\section{Ground Subsidence}

Ground subsidence was assessed by stretching a steel tape horizontally across a right-of-way at the ground surface level of the undisturbed control section and, subsequently, measuring vertically down from the tape to the collapsed right-of-way.

\section{$\underline{\text { Soils }}$}

Soil pits were dug to a depth of $1 \mathrm{~m}$ or the depth of the frost table at the microclimate measurement transects in both disturbed and control sites. Epipedon degradation on corridors (in terms of stripped, compacted, and eroded upper soil horizons and organic layers) was assessed by comparative measurement of the proportions of diagnostic soil horizons and layers in the control section and on the disturbed surfaces. A classification of the undisturbed soils in the control sections was attempted on the basis of diagnostic soil horizons and their morphological characteristics (Appendix A). Soil taxonomy follows "The Canadian System of Soil Classification" (Expert Committee on Soil Survey, 1987). 


\section{CHAPTER V}

\section{DATA ANALYSIS}

Winter road operations in permafrost terrain generate a sequence of ecological consequences. This chapter is concerned with some of the key components of the ecosystem affected by long-term perturbations in the tundrataiga ecotone -- microclimate, permafrost, terrain morphology, soils, and vegetation.

\section{CHANGES IN MICROCLIMATE}

The influence of climate on the ground thermal regime of Subarctic forests is conditioned by surface characteristics, which determine the magnitude of the individual component processes of the surface energy regime (Brown, 1966; Benninghoff, 1966).

Solar Radiation

The loss of plant canopy stratification on winter road right-of-ways, following clearing, results in a significant modification of the radiant energy budget. Practically all of the incoming solar radiation reaches the road surfaces during high sun angles, while in the adjacent control, a considerable fraction of the shortwave radiation is trapped, absorbed or reflected by the vegetation 
canopy. On August 1, at Site \# 3 (Jackfish Creek) daily totals of $19.7 \mathrm{MJm}^{-2}$ were tallied from hourly measurements on the sparsely vegetated roadway, compared to $3.6 \mathrm{MJm}^{-2}$ on the control surface; a closed black spruce / heath / feathermoss association (Figure 5a). This comparison translates into a fivefold increase of shortwave radiation receipt on the disturbed surface. On the other hand, incoming solar radiation in the forest-tundra at Site \# 9 (Campbell Creek, Transect 1) was higher on the control surface; an open, sparse black spruce / heath community, than on the roadway site where vigorously growing sedges (Carex spp.), tall cottongrass (Eriophorum angustifolium) and swamp horsetail (Equisetum fluviatile) shaded the ground surface (Figure 5b). Shading of road surfaces is further controlled by orientation of the corridor with respect to the solar path, sun angles, as well as height and density of the tree and shrub canopy in the control. These effects are illustrated at Site \# 8 (Mackenzie Highway - Dempster Highway Junction), an east-south-east oriented corridor through a closed black-spruce / heath association (Figure 6). The roadway surface was shaded from sunrise until about 9:40 hr local apparent solar time (11:30 hr standard time), when irradiance values markedly increased due to receipt of direct-beam solar radiation. The receipt of shortwave radiation decreased steeply after 14:10 hr local apparent solar time (16:00 hr standard time), when the adjacent vegetation shaded the road surface again. 


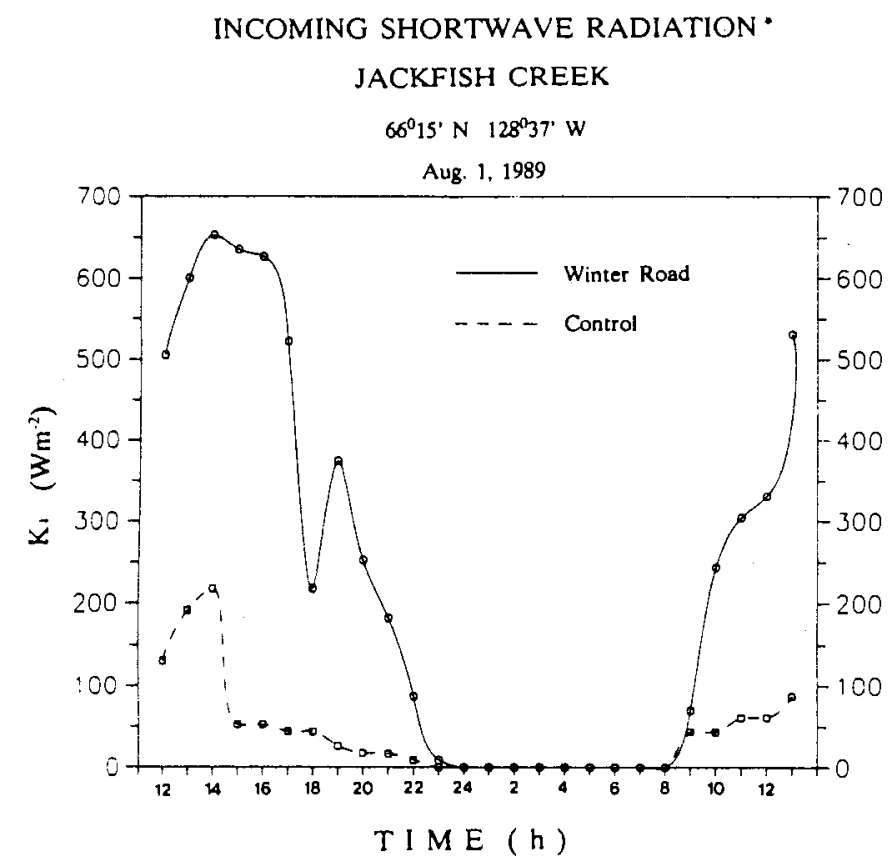

INCOMING SHORTWAVE RADIATION *

CAMPBELL CREEK

$68^{\circ} 35^{\prime} N$ N $133^{\circ} 14^{\prime} W$

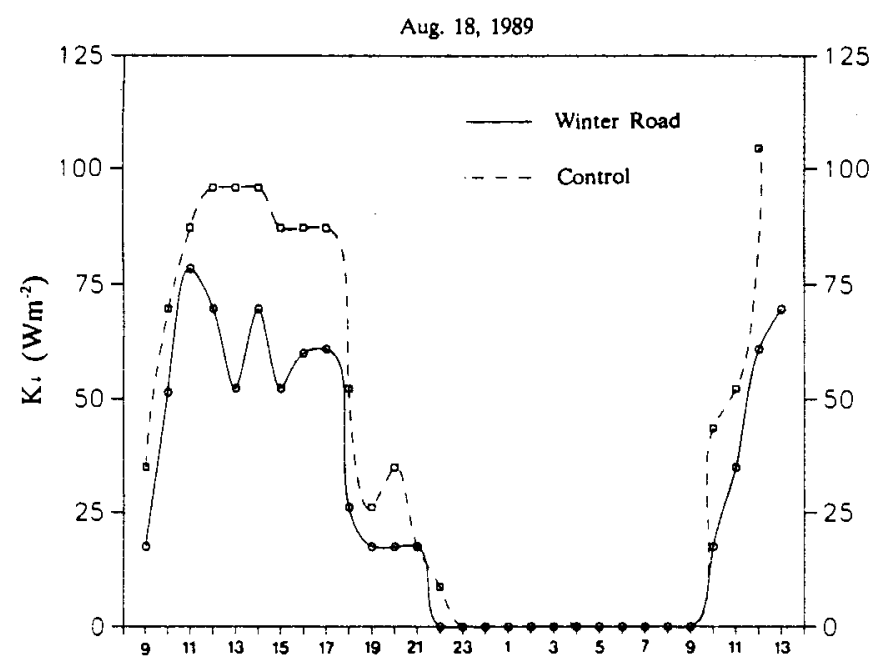

b

TIME ( h )

Figure 5. Solar radiation received at the ground surface. a) on a sparsely vegetated roadway surface, and in the adjacent control, a closed black spruce / heath association (Site \# 3); b) on a densely vegetated by cottongrass, and in the adjacent control, an open, poorly grown black spruce / heath community (Site \# 9). 


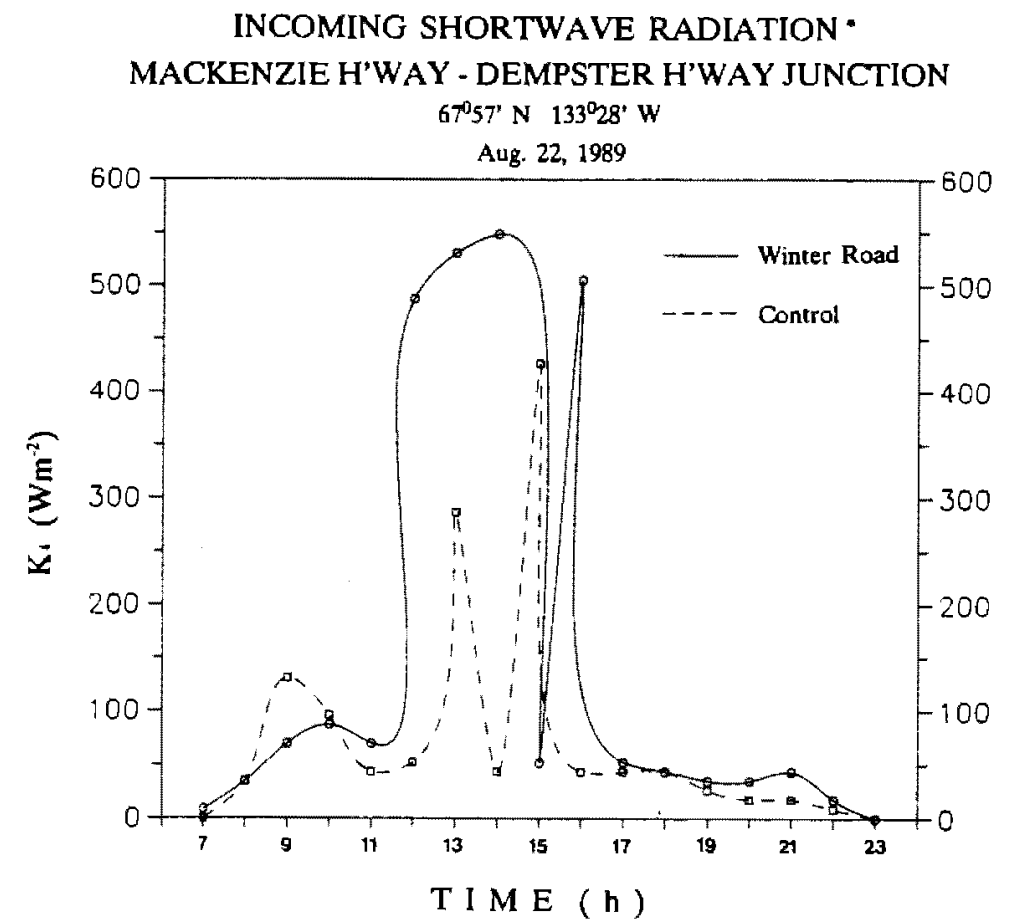

Figure 6. Effects of roadway orientation on irradiance. Measurements taken at the ground surface of a sparsely vegetated, ESE-oriented roadway surface and in the adjacent control, an open black spruce / heath association. Note the marked increase in irradiance on the roadway around 11:30 hr (standard time) due to exposure to direct sunlight, and the steep decrease after 16:00 (standard time) when the adjacent forest shades the roadway surface again. 
Differences in radiative receipt between roadway and control sites diminish with increasing latitude due to progressively sparser tree and shrub canopy and, hence, increased sky view factors. This implies that energy budget changes, following surface disturbance, and adjunct implications on microclimate, permafrost, and vegetation, are more substantial in the boreal forest than in the forest-tundra.

\section{$\underline{\text { Surface Albedo }}$}

Due to a simplification of vegetation stand architecture, caused by the removal of tree and shrub strata, mean midday surface albedo increased from an average of 0.13 in the control areas to 0.16 on the roadways, regardless of latitude. The mean albedo of 0.13 for undisturbed spruce forest conforms with values of $0.13,0.12$ and 0.13 reported for open spruce forest by Haag (1973), Rouse and Bello (1983) and Rouse (1984), respectively. The recorded mean of 0.16 for roadways approximates values of 0.15 reported for upland tundra by Rouse (1984) and Petzold and Rencz (1975), respectively.

In the closed boreal forest, changes in surface albedo are assumed to significantly affect the surface energy exchange, in view of the substantial increase in shortwave radiation reaching the ground following vegetation clearing. In contrast, in open forest-tundra slight modifications of the albedo are expected to be rather inconsequential. 
Soil Heat Flux

Vegetation clearing, the complete or partial removal of the organic mat, and soil compaction by vehicular movement (Haag and Bliss, 1974; Adam and Hernandez, 1977), enhance the penetration of energy into the ground, and thus, heat exchange in the substrate. Roadways exhibit increased net downward flux for the measurement periods, compared to adjacent control sites. However, heat storage in the ground decreases as the late summer advances, and with latitude, due to lower temperatures and shorter daylight periods (compare Figures $7 \mathrm{a}$ and $\mathrm{Tb}$ ). Soil heat flux is more pronounced in its diurnal range on the investigated right-of-ways than in the control areas, where desiccated surface peat layers inhibit moisture and heat exchange (Figures $7 a-7 d)$. Positive soil heat flux (soil warming) is attained in roadway soils later in the morning than in the control areas, due to substantial heat losses from the denuded surfaces during the night (Figures $7 \mathrm{a}-7 \mathrm{~d}$ ).

In soils with abundant moisture supply, the amplitude of the recorded soil heat flux is markedly smaller than on dry sites with comparable substrate (compare Figures $7 \mathrm{c}$ and $7 \mathrm{~d}$ ). This is attributed to increased evaporative losses from wet soils, through which substantial amounts of latent heat are released and the cardinal portion of the ground heat flux is realized. Measurements with heat flow plates only determine the sensible heat flow. They do not reflect the gross ground heat flux which is comprised of both latent heat and sensible heat 
SOIL HEAT FLUX DENSITY

CANYON CREEK

$65^{\circ} 13^{\circ} \mathrm{N} 126^{\circ} 32^{\prime} \mathrm{W}$

July $16 \& 17,1999$

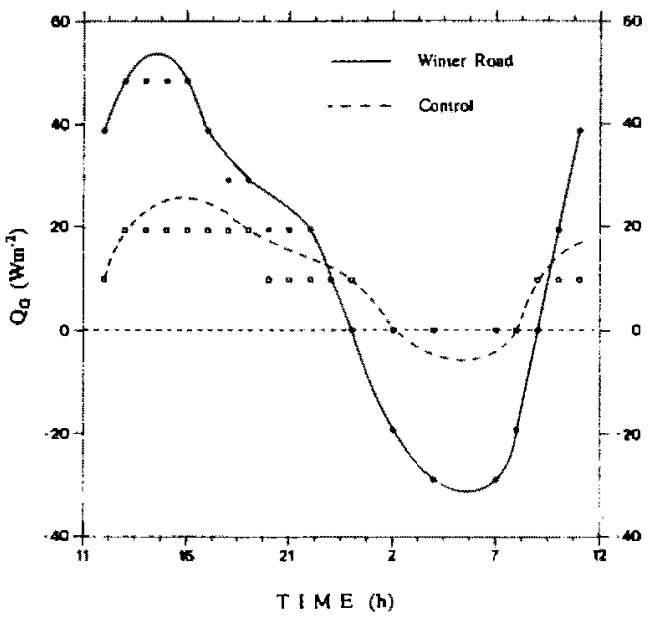

a

SOIL HEAT FLUX DENSITY

JACKFISH CREEK

$66^{0} 15^{\circ} \mathrm{N} 128^{\circ} 37^{\prime} \mathrm{W}$

July $30 \& 31,1989$

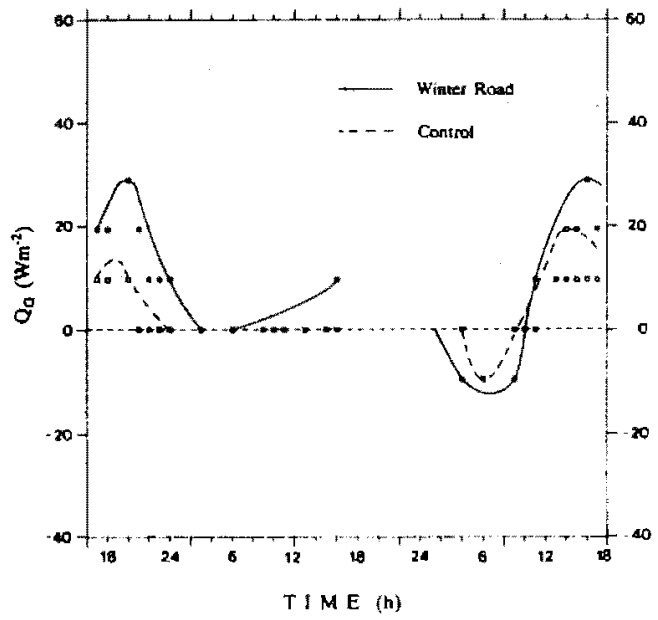

C
SOIL HEAT FLUX DENSITY

MACKENZIE H'WAY - DEMPSTER H'WAY JUNCTION $67^{\circ} 57^{\circ} \mathrm{N} 133^{02} 28^{*} \mathrm{~W}$

Aug. $23 \& 24,1989$

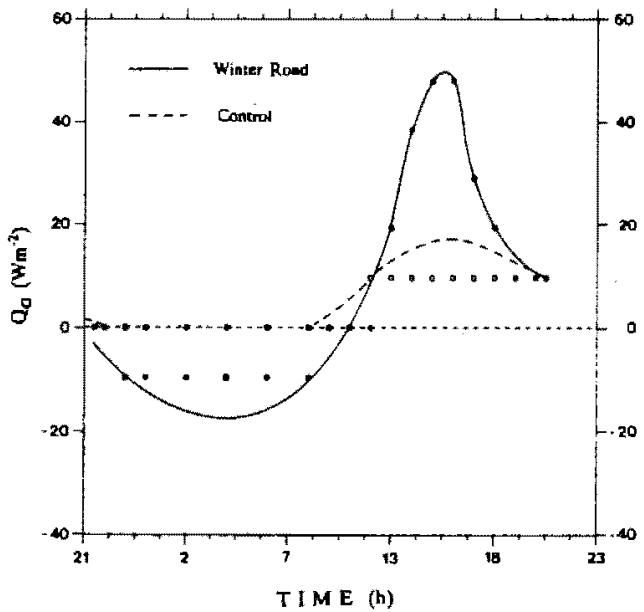

b

SOIL HEAT FLUX DENSITY

LITTLE CHICAGO

$67^{0} 12^{\prime} \mathrm{N} 130^{\circ} 12^{\circ} \mathrm{W}$

Aug. $7 \& 8,1989$

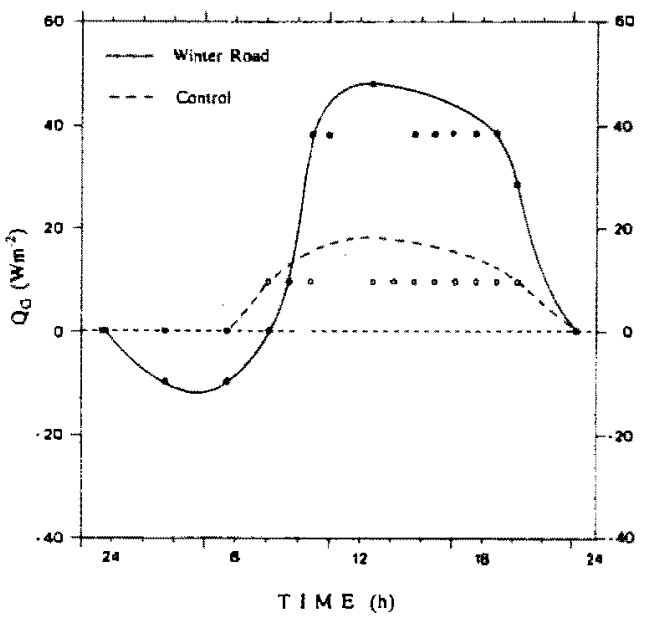

d

Figure 7. Diurnal range of soil heat flux. a) during mid-summer: 15 hours of heat gain, 9 hours of heat loss (Site \# 1); b) during late summer: 10 hours of heat gain, 14 hours of heat loss (Site \# 8); c) on a wet roadway (Site \# 3); d) on a dry roadway (Site \#6). 
terms. Therefore, the data presented (Figures $7 \mathrm{a}-7 \mathrm{~d}$ ) does not give a comprehensive appraisal of the ground heat flux. Since the sensible heat flux shows no correlation to latent heat flow, extrapolation of the latter is unobtainable (Rouse, 1984).

\section{Surface and Air Temperatures}

Mean daily air and soil temperature differences between roadways and the adjacent control, calculated by integration of hourly temperature differences, are presented in Table IV. Mean air temperatures are consistently higher on the roadways than in the control since road surfaces remain largely unshaded during the day. Periodically, however, daytime surface and air temperatures drop below those recorded in the control due to increased air movement over the right-of-ways and, in turn, greater heat transport away from the ground surface. Nocturnal surface temperatures are consistently higher on roadways than in the control sections owing to ameliorated mixing of near-surface air layers and an increased upward soil heat flux. Air temperatures are typically higher on the roadways for the first half of the night, but drop below those recorded in the control for several hours until dawn. This may be explained by a more gradual decrease in temperature in the control due to absorption of longwave radiation lost from the surface by the tree and shrub canopy. Increased $\mathrm{CO}_{2}$ and water vapor levels in the control influence night air temperatures to a lesser extent by increasing the heat capacity and thermal 


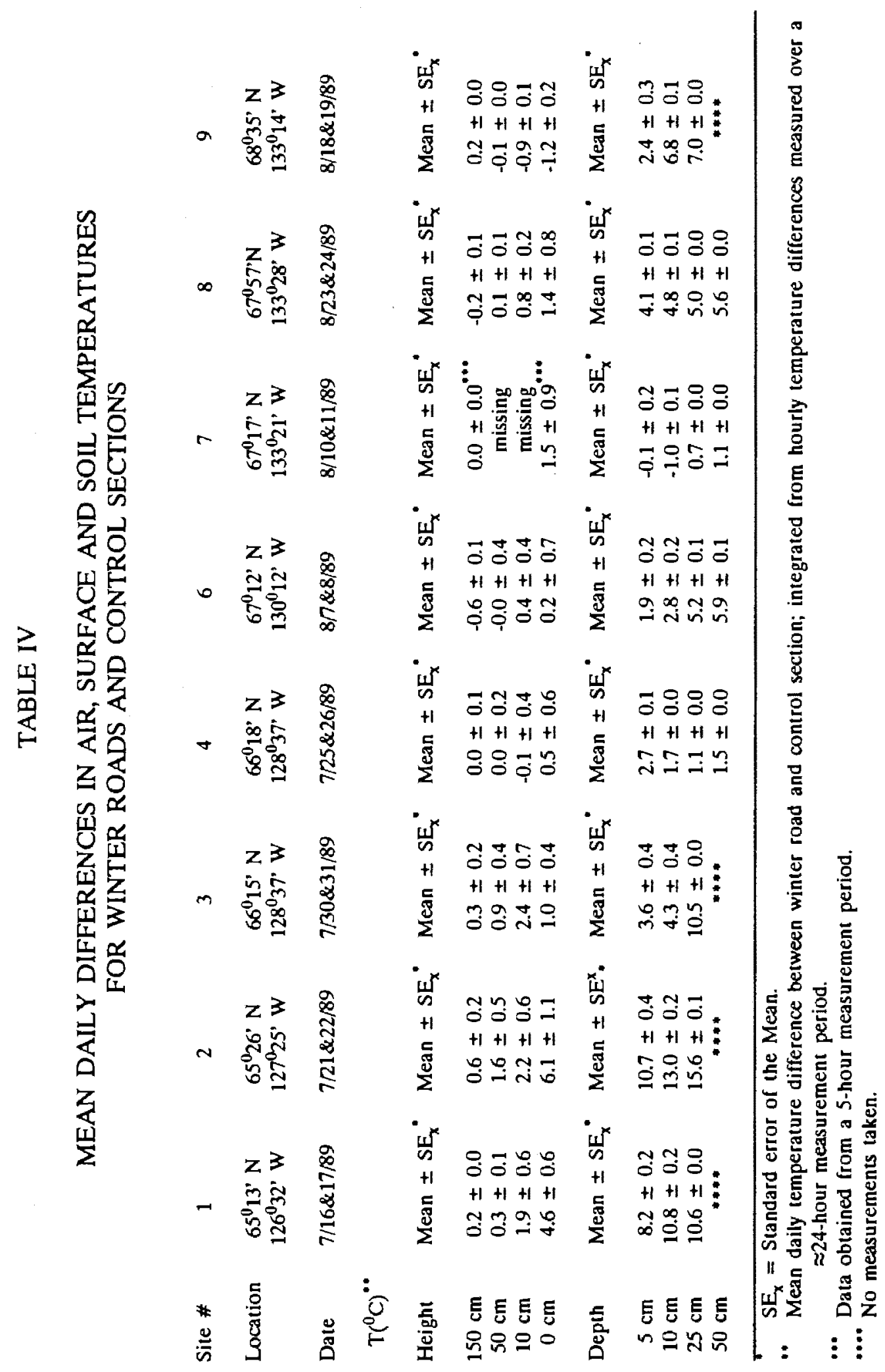


conductivity of the air (Haag and Bliss, 1974).

Nocturnal temperature inversions develop at all sites and become progressively more stable as the late summer advances. Calm, clear-sky conditions favor stronger inversions on roadways than in the control, suggesting higher probabilities for night frost during the spring and fall. Vertical lapse rates are generally more pronounced on roadways which offer less resistance to heat transport away from the surface than the control sections. Mean daily air temperature differences between roadway and control sections decrease consistently with height above the ground due to increased turbulent diffusion of air layers. Further, differences in air and surface temperatures diminish with increasing latitude, owing to progressively sparser tree cover.

One exception to typical conditions is Site \#9 (Table IV). Soils on the subsided right-of-way are water-saturated and support densely growing sedges and cottongrass which shade the ground. Any heat received at the surface quickly dissipates into the ground as a result of its large thermal mass. During the night, surface and near-surface air temperatures remain higher on the roadway than in the control owing to the thermal inertia of the saturated soil and decreased heat transport away from the densely growing vegetation.

\section{Soil Temperatures}

Soil temperatures are consistently higher on the roadway during the midand late summer, because of long daily insolation periods and, hence, an 
increased positive heat flux (Table IV). Mean daily differences in soil temperatures between roadways and control sections increase with depth due to deeper active layers on the roadway. Moreover, temperature differences appear to decrease with increasing latitude which may be attributed to progressively colder soil climate.

Site \# 7 (Table IV) exhibits an exceptional profile of soil temperature differences; at depths of 5 and $10 \mathrm{~cm}$, temperatures are higher in the control than on the roadway, whereas at lower depths the opposite holds true. An explanation may be the fire history of the site: less than two years before the field visit, an intense fire had completely consumed the forest including peat layers of approximately $30 \mathrm{~cm}$ thickness (Anonymous, 1975b). However, the bare road surface provided little combustible material, thus, was little impacted by the fire. At the time of the field visit the ground surface in the control area was still charred and absorbed the incoming solar radiation more effectively than the roadway. Near-surface soil temperatures would, thus, be expected to increase relative to the roadway. The reversal of the temperature profile at greater depths, on the other hand, is attributed to a deeper active layer on the right-of-way than in the control.

The range of diurnal soil temperature fluctuation is consistently greater beneath disturbed surfaces (Table V) as a result of the partial or complete removal of the insulating vegetation and the organic mat, as well as increased 


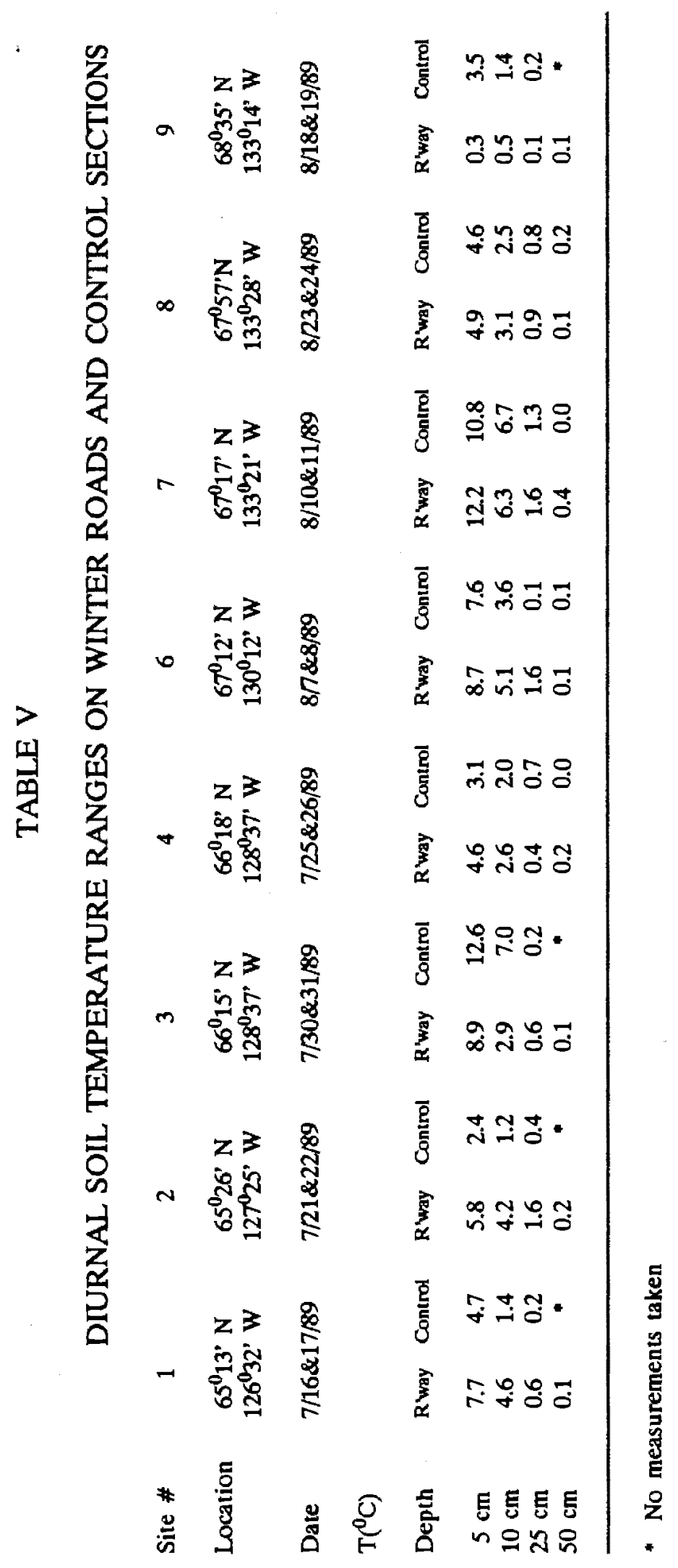


thermal conductivities and compacted near-surface soil layers. However, the actual range of diurnal temperature variation is related to the depth of measurement, the moisture regime and thermal conductivity of the soil. Due to the thermal inertia of water, wet sites (Table V, Site \# 9) exhibit smaller diurnal temperature ranges in both disturbed or undisturbed soils than dry or mesic sites (Table V, Sites \# 1,2, and 6). The most marked diurnal temperature oscillations are observed on the recently burned Site \# 7 (Table V).

\section{CHANGES IN NEAR-SURFACE PERMAFROST CHARACTERISTICS}

The environment in which permafrost exists is a complex dynamic system, easily influenced by alterations of the prevailing environmental conditions (Brown, 1970). Whereas permafrost in tundra areas is predominantly controlled by the regional climate (French, 1976), its existence and nature in the forested reaches of the Subarctic is primarily determined by vegetation characteristics. The potential for long-term damage to near-surface permafrost, following removal of the vegetative cover, increases with complexity of vegetation stratification (Haag, 1973). In the following, additional factors influencing the extent of permafrost degradation in the context of winter road operation are discussed, including the effect of peat layers, soil moisture regimes, and disturbances by fire. 


\section{Active Layer Depth}

As a result of higher soil temperatures, depth of the active layer is increased on all disturbed surfaces (Table VI). During field work, mean thaw depths on the right-of-ways exceeded the control values by $105 \% \pm 15 \%$. This value is expected to have further increased as the thaw season advanced since frost table depths were probed about 65 to 30 days before the active layer attained its maximum depth.

The smallest increase in thaw depth averages $17 \%(11 \mathrm{~cm})($ Table VI, Site \# 6, Transect 3) where peat layers of $20+\mathrm{cm}$ are preserved on an abandoned roadway, vegetated by a graminoid / willow association. In contrast, the most significant deepening of the active layer occur where the insulative organic mat has been removed (Figure 8). Increases on the order of $313 \%$ (94 $\mathrm{cm}$ ) are assessed on a right-of-way at Site \# 1 (Table VI, Transect 2) which has been in perennial winter operation for at least 10 years. Here, the organic mat has been removed entirely (about $16 \mathrm{~cm}$ ) and about $8 \mathrm{~cm}$ of compacted mineral soil have been stripped. The right-of-way supports a graminoid association, providing only little insulation.

Soils with aqueous (hydric) or aquic moisture regimes thaw to greater depths than dry or moist deposits, owing to increased thermal conductivities of the water-saturated substrate (Brown, 1970). However, the findings of this study, demonstrate that, following disturbance, mean increases in thaw depth are 


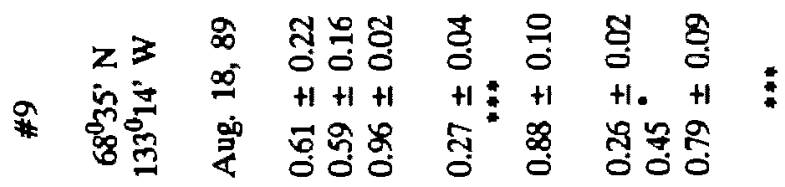

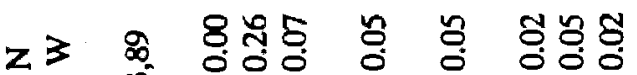

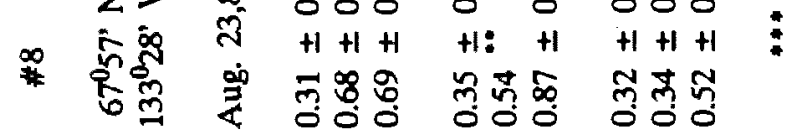

客.

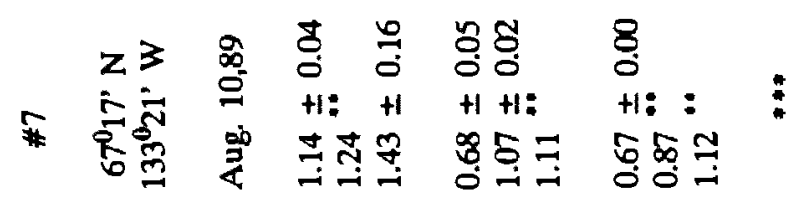

乙。

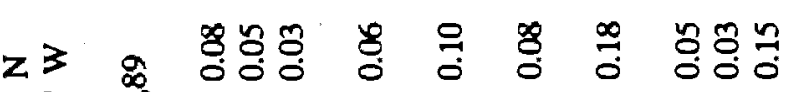
$\approx \approx \sim 1+1+$ H: +1 +1: +1 $+1+1+1$

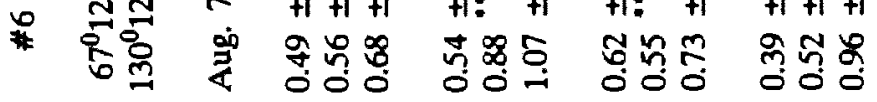

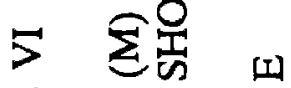

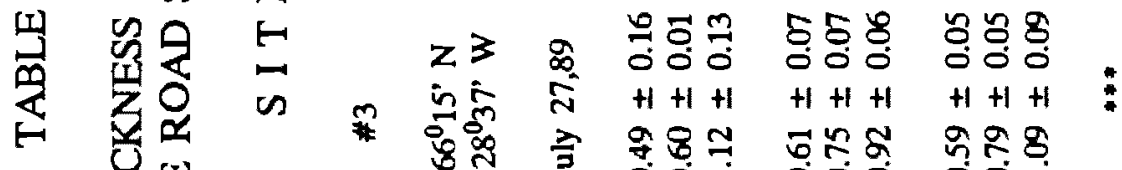

突罣

发写

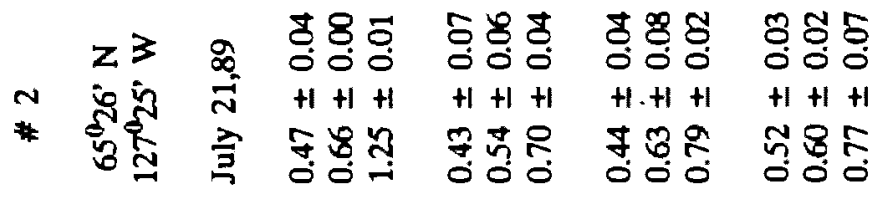

$\sum^{\text {UI }}$

- $z 3$ \&

* in

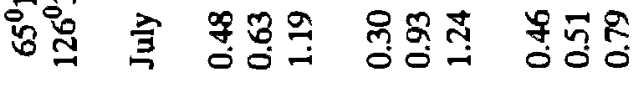

핓

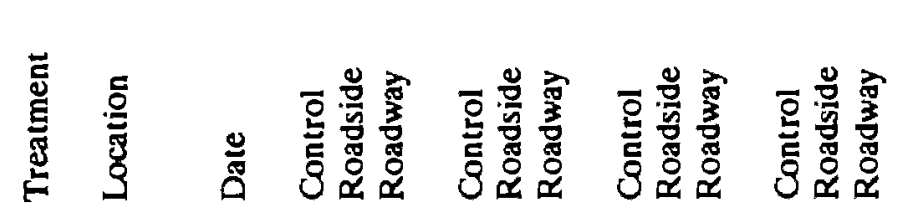

$N$

$m$

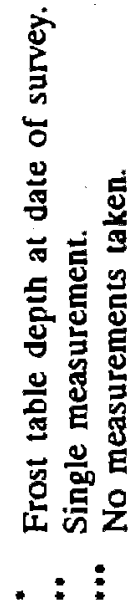




\title{
ACTIVE LAYER DEPTH
}

\author{
Canyon Creek \\ $65^{\circ} 13^{\prime} \mathrm{N} 126^{\circ} 31^{\prime} \mathrm{W}$
}
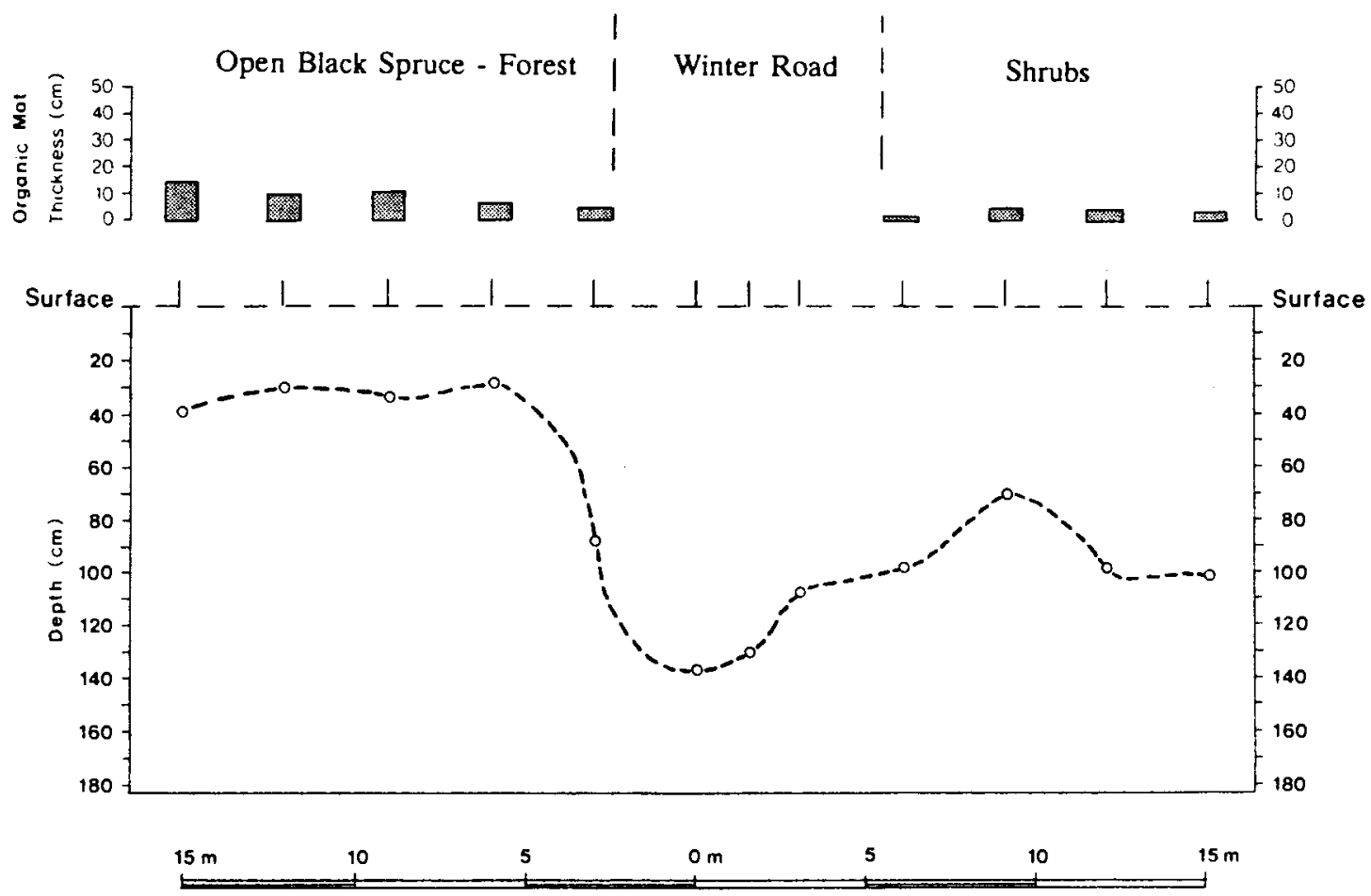

Figure 8. Active layer depth across an actively used roadway denuded of the organic mat and the upper mineral soil layers. Differences in surface elevations between roadway and the adjacent control are ignored. Note the influence of vegetation type and depth of the organic mat on thaw depths in the control. 
significantly smaller at water-logged sites $(53 \%)$ than on dry sites $(153 \%)$ suggesting lower sensitivity of saturated sites to near-surface permafrost degradation. This is attributed to substantial latent heat uptake by wet soils through which the cardinal portion of the ground heat flux is realized. In contrast, dry soils experience considerable sensible heating as a result of low actual evaporative losses.

Active layer response to forest fire is found to be variable and seems related to the severity of the disturbance. At Site \# 6 (Table VI, Transect 4), roughly five years prior to the field visit, a fire of low intensity had consumed the tree canopy, but the organic mat, preserved at $20 \mathrm{~cm}$ to $40 \mathrm{~cm}$, was only singed. Thaw depth in the burned control area has increased negligibly to a mean of $39 \mathrm{~cm}$. However, on the roadway, little peat remains as a result of winter road operation. As a result, active layer depths on the roadway exceed those in the burned control area by $146 \%(57 \mathrm{~cm})$, a value notably increased relative to probings on three unburned transects on the site $(17 \%, 38 \%$, and $98 \%$ ).

Contrasting observations on the effects of fire on near-surface permafrost are made at Site \# 7, where a wildfire of significantly greater intensity had occurred less than two years before the field visit. While the right-of-way, already abandoned for roughly eight years when the fire occurred, had provided little combustible material, the adjacent forest and peat layers of approximately 
$30 \mathrm{~cm}$ (Anonymous, 1975b) were completely consumed. As would be expected, the active layer in the burned control site has deepened significantly, whereas the fire impact results in only negligible changes in the ground thermal regime of the roadway site. Consequently, increases in thaw depth on the right-of-way $(25 \%, 63 \%$, and $67 \%$ at transects 1,2 , and 3 , respectively; Table VI), resulting from the joint impact of winter road operation and the fire, are smaller than at most other sites which have not been exposed to recent fires.

\section{Ice Content}

Previous terrain disturbance studies have indicated that increased terrain damage and, thus, the degradation of near-surface permafrost, causes a proportionate decrease in the ground ice content (Heginbottom, 1974; Kurfurst, 1974; Heginbottom and Kurfurst, 1977). The findings of this study along the Lower and Central Mackenzie River substantiate these observations (Figure 9). Loss of excess ice, determined gravimetrically on a per cent basis of dry weight, ranges between $23 \%$ and $82 \%$ relative to the control, and is attributed to subsurface drainage of excess water from supersaturated thawing soils.

\section{GROUND SUBSIDENCE}

Previous winter road studies report only insignificant changes in surface elevation following temporary right-of-way operations (Canadian Arctic Gas 


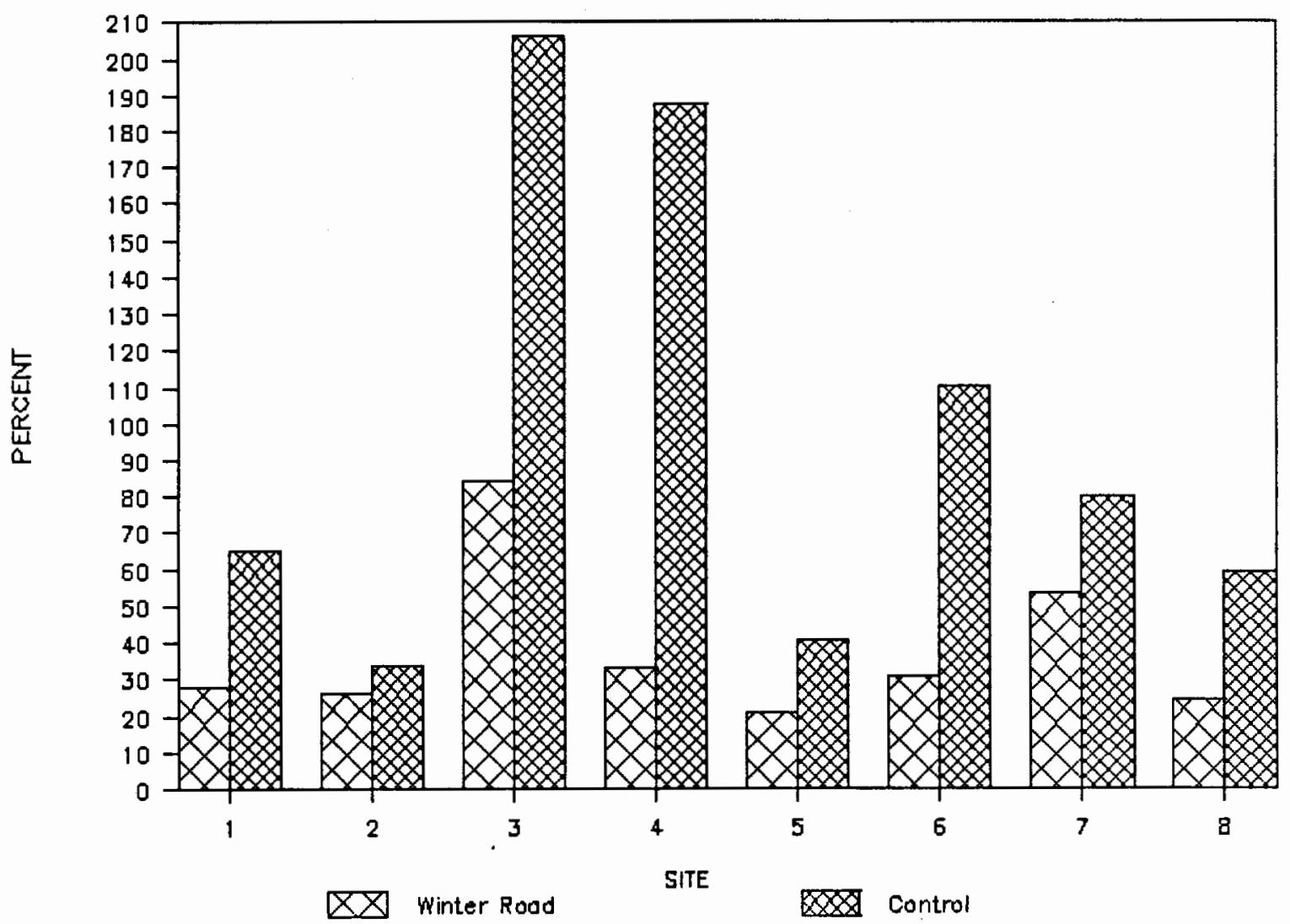

Figure 9. Ice content in $\%$ of dry weight at the bottom of the active layer. 
Study Ltd., 1974; Adam and Hernandez, 1977; Younkin and Hettinger, 1978). However, the findings of this study on long-term effects of winter road operations, prove that substantial ground settlement may result, particularly, where the thermal regime of excessively ice-rich sediments is altered (Table VII, Sites \# 2 \& 3).

Surface subsidence occurs on all of the investigated right-of-ways, and is generally uniform across the roadway surface unless, localized, massive ground ice has thawed (Figure 10a) (Table VII). At Site \# 2, differential terrain collapse, apparently resulting from the thaw of a massive body of segregational ice or an ice wedge in the silty clay deposits of an alluvial meander plain, impairs the trafficability of the right-of-way. Localized, ground subsidence disrupts the local drainage pattern. As a result, site wetness increases or surface water is impounded (Figure 10b).

TABLE VII

GROUND SUBSIDENCE (CM) ON ROADWAYS

\begin{tabular}{|c|c|c|c|c|}
\hline Site \# & Location & Lithology & Subsi & e $(\mathrm{cm}$ \\
\hline & & & Min. & Max. \\
\hline 1 & $65 \quad 13^{\prime} \mathrm{N} 126 \quad 32^{\prime} \mathrm{W}$ & silty clay till & 0 & 20 \\
\hline 2 & $6526^{\prime} \mathrm{N} 12725^{\prime} \mathrm{W}$ & deltaic silty sand & 15 & 105 \\
\hline 3 & $6615 \mathrm{~N} 12837 \mathrm{~W}$ & deltaic sand & 25 & 84 \\
\hline 4 & $6618^{\prime} \mathrm{N} 12837^{\prime} \mathrm{W}$ & silty clay till & 0 & 15 \\
\hline 6 & $67 \quad 12^{\prime} \mathrm{N} 130 \quad 12^{\prime} \mathrm{W}$ & glaciolacustrine sandy clay & 20 & 40 \\
\hline 7 & $6717{ }^{\prime} \mathrm{N} 13321 \mathrm{~W}$ & glaciolacustrine silty clay & 0 & 25 \\
\hline 8 & $6757^{\prime} \mathrm{N} 13328^{\prime} \mathrm{W}$ & silty clay till and & & \\
\hline 8 & continued & glaciofluvial gravels & 44 & 66 \\
\hline 9 & $\begin{array}{lll}68 & 35 \\
\end{array}$ & silty clay till & 8 & 60 \\
\hline
\end{tabular}



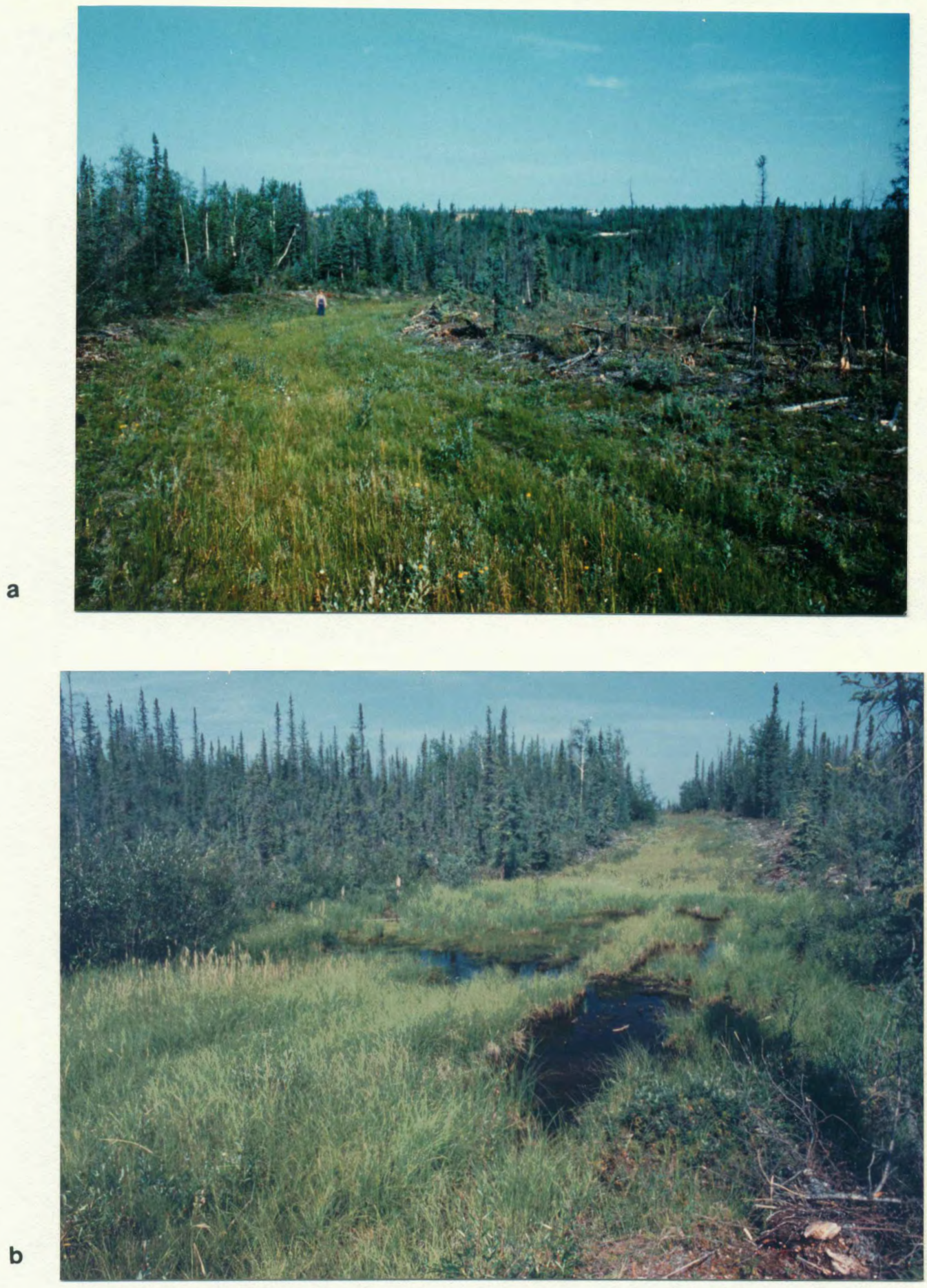

Figure 10. Ground subsidence on right-of-ways. a) uniform thaw settlement in excess of $1 \mathrm{~m}$ due to thawing of supersaturated sediments (Site \# 3); b) differential thaw settlement (Site \# 3 ) resulting from the thaw of ice wedges. Water is impounded in vehicle tracks and the thaw depressions. Black spruce in the adjacent control averages $3.5 \mathrm{~m}$ in height. Roadway vegetation dominated by sedges and grasses. 
Relief changes on the investigated right-of-ways are attributed primarily to thermokarst collapse on sites with supersaturated frozen sediments and subsequent thaw consolidation of the substrate. Additionally, ground surface subsidence is augmented by the removal or compaction of organic and mineral soil layers, and to a lesser extent, seasonal variations in thaw subsidence owing to discordant thaw rates on roadways and in the control.

\section{SOIL DEGRADATION}

This portion of the study is concerned with the differences between control soils and disturbed site substrates. Soil degradation includes: a) the stripping or deterioration of the organic mat and mineral soil layers, b) the scuffing of earth hummocks in areas of hummocky microrelief, c) the rutting of the ground surface by vehicle tires, and d) the compaction of upper soil layers (Haag and Bliss, 1974; Adam and Hernandez, 1977). However, the long-term evolution of initial minor disturbances increases the impact by e) the hydraulic erosion of exposed top soil layers (particularly fine fractions), f) the unearthing of rocks in areas of coarse moraine till, and g) the impounding of surface water as a result of thaw subsidence. 
On upland terrain, stripping or churning of the organic mat, and scuffing of earth hummocks is practically unavoidable during the initial right-of-way clearing and winter road preparation in early winter (Linton, Interview, 1989). Furthermore, the operation of heavy equipment, vehicles with high tire pressures or cleated tracks results in the crushing of the frozen stems, leaves and roots of upright vegetation and the organic mat (Felix and Reynolds, 1989). Due to exposure to sunlight, the light-sensitive feathermosses, normally the dominant form of ground cover, die back completely upon right-of-way clearing in the first summer following construction (Adam and Hernandez, 1977). Perennial operation of a winter road causes the disintegration of plant parts and ultimately the pulverization of peat fibers. Upon desiccation, these particles are subject to deflation or erosion. However, peat layers in fenlands or depressional roadway sections remain largely undisturbed because the frozen water-logged soils compact less under the impact of vehicular traffic than their dry upland counterparts (Wein and Bliss, 1971).

The findings of this study substantiate the fact, that the organic mat is significantly reduced in thickness or completely removed at dry and mesic roadways which have been operated perennially (Figure 11), whereas peat layers on wet and water-logged roadway sections are largely preserved. Average loss of soil material (including the organic mat) ranges between $3 \mathrm{~cm}$ and $35 \mathrm{~cm}$, varying with severity of the impact (Table VIII). Earth hummocks have been 


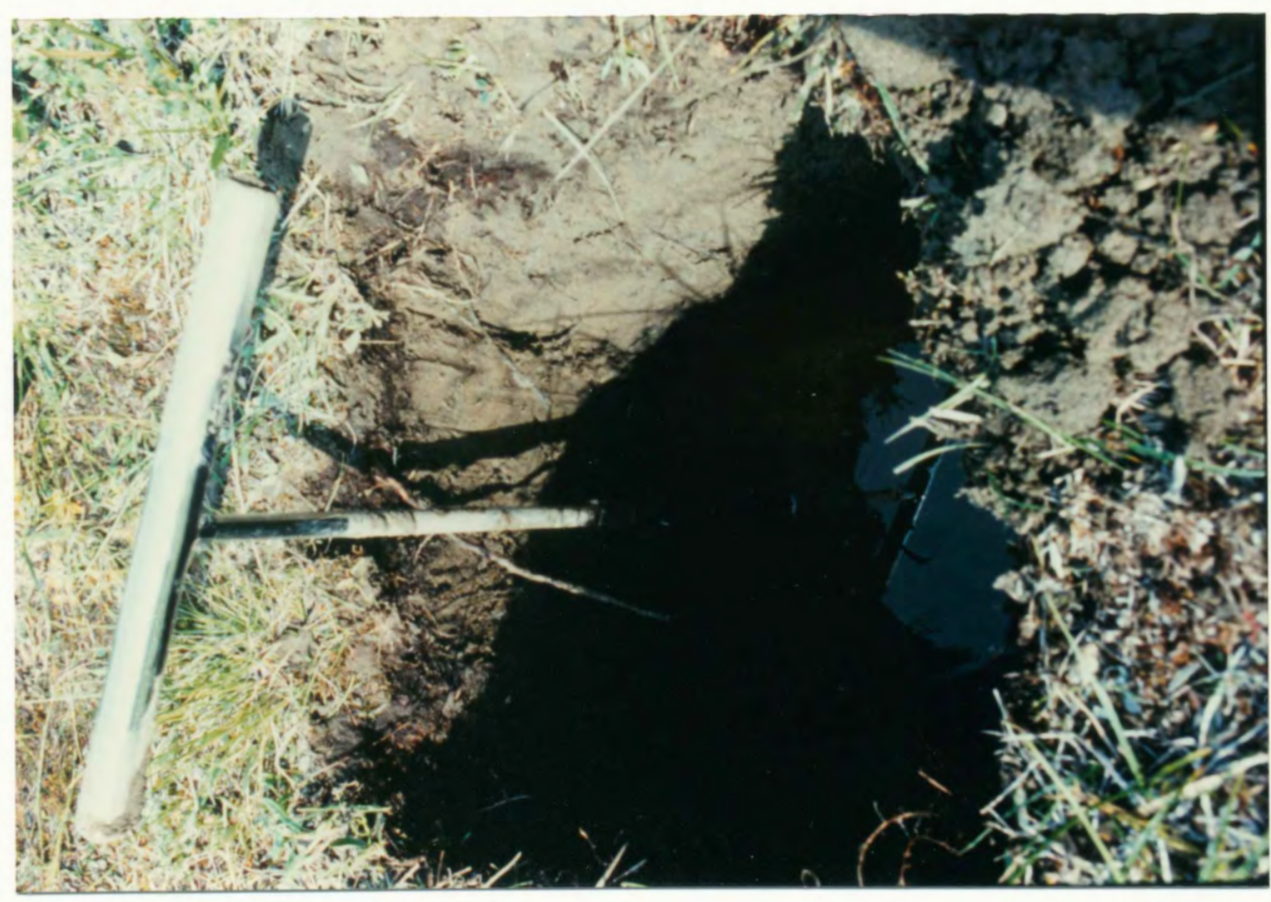

ค

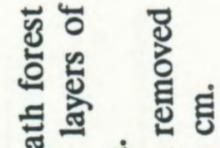

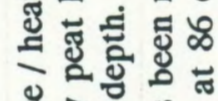

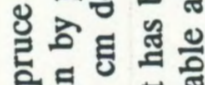

的

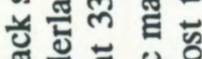

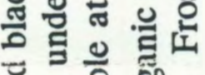

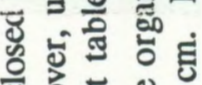

융 氙

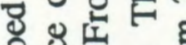

总焉的药

氬空

寻芯芯

도

ส

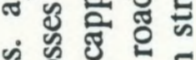

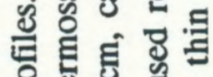

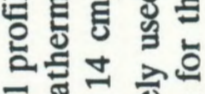

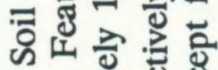

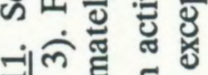

귀ำ

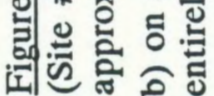

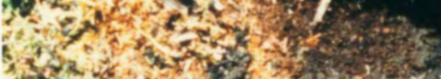

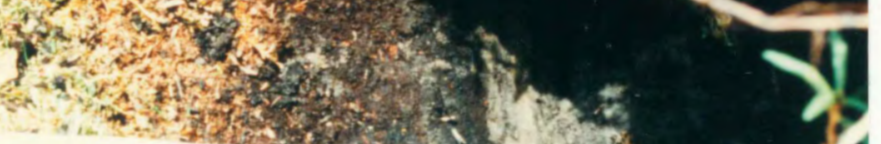

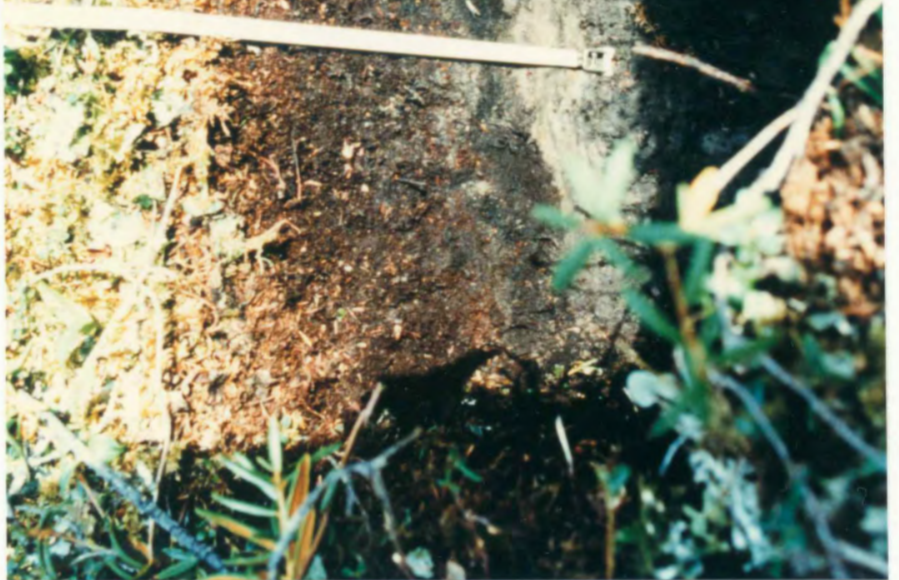


scuffed by as much as $25 \mathrm{~cm}$ (Figure 12).

Surface rutting occurs on all slopes greater than $6^{\circ}$ and where winter roads have been operated too late in the spring (Figure 13a). Similarly, the unseasonal use of All-Terrain-Vehicles on the right-of-ways results in excess disturbance and causes hydraulic surface erosion (Figure 13b). Stream banks and approaches to stream crossings, potentially the most critical areas (Adam, 1974), exhibit no signs of instability where streamflow is confined to the summer. However, at the perennially flowing Canyon Creek (Site \# 1, Figure 1) gravel bank erosion at an existing ice bridge crossing has required the construction of a lateral bypass. In areas of coarse moraine till (Site \# 4, Site \# 8, Transect 4) rocks are unearthed more frequently on roadways than in the control sections suggesting their indirect exhumation by erosion of fines (Figure 14).

Alternatively, changes in the ground thermal regime, following surface disturbance, may be responsible for increased upfreezing of the rocks.

\section{TABLE VIII}

AVERAGE LOSS OF SOIL MATERIAL (CM) ON ROADWAYS

\begin{tabular}{|c|c|c|c|c|}
\hline Site \# & Location & Average Los & of Soll Materie & (cm) \\
\hline & & Organic Mat & Mlneral Soll & Total \\
\hline 1 & 65 13'N $12632 \mathrm{~W}$ & 16 & B & 24 \\
\hline 2 & $6526^{\prime} \mathrm{N} 12725^{\prime} \mathrm{W}$ & 19 & 1 & 20 \\
\hline 3 & $\begin{array}{llll}66 & 15^{\prime} \mathrm{N} & 128 & 37^{\prime} \mathrm{W}\end{array}$ & 14 & 0 & 14 \\
\hline 4 & $66 \quad 18^{\prime} \mathrm{N} \quad 128 \quad 37^{\prime} \mathrm{W}$ & 35 & 0 & 35 \\
\hline 6 & $67 \quad 12^{\prime} \mathrm{N} \quad 130 \quad 12^{\prime} \mathrm{W}$ & 0 & 17 & 17 \\
\hline 7 & $6717^{\prime} \mathrm{N} 13321^{\prime} \mathrm{W}$ & 4 & 4 & 8 \\
\hline 8 & $6757^{\prime} \mathrm{N} \quad 133 \quad 28 \mathrm{~W}$ & 0 & 3 & 3 \\
\hline 9 & $6835^{\prime} \mathrm{N} 133 \quad 14^{\prime} \mathrm{W}$ & 22 & 5 & 27 \\
\hline
\end{tabular}




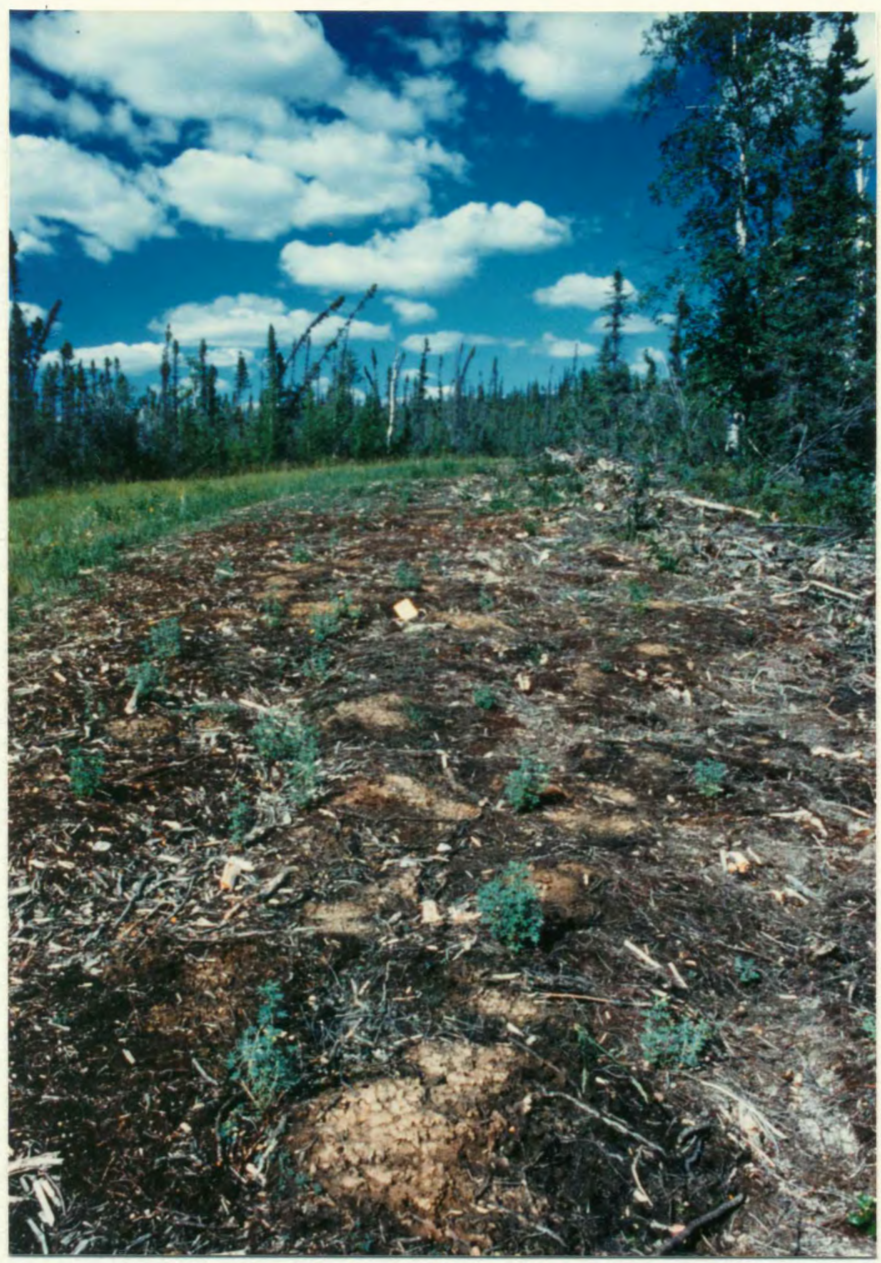

Figure 12. Scuffed earth hummocks. Note book for scale. The road shoulder has been cleared to a width of $6 \mathrm{~m}$ to enhance visibility in a road bend (Site \# 1). Peat layers are preserved at $10-15 \mathrm{~cm}$ and inhibit revegetation due to summer drought. The grass-covered roadway, on the left, has been in operation for at least the past 18 years. Trees in the adjacent control average $6.5 \mathrm{~m}$ in height. 

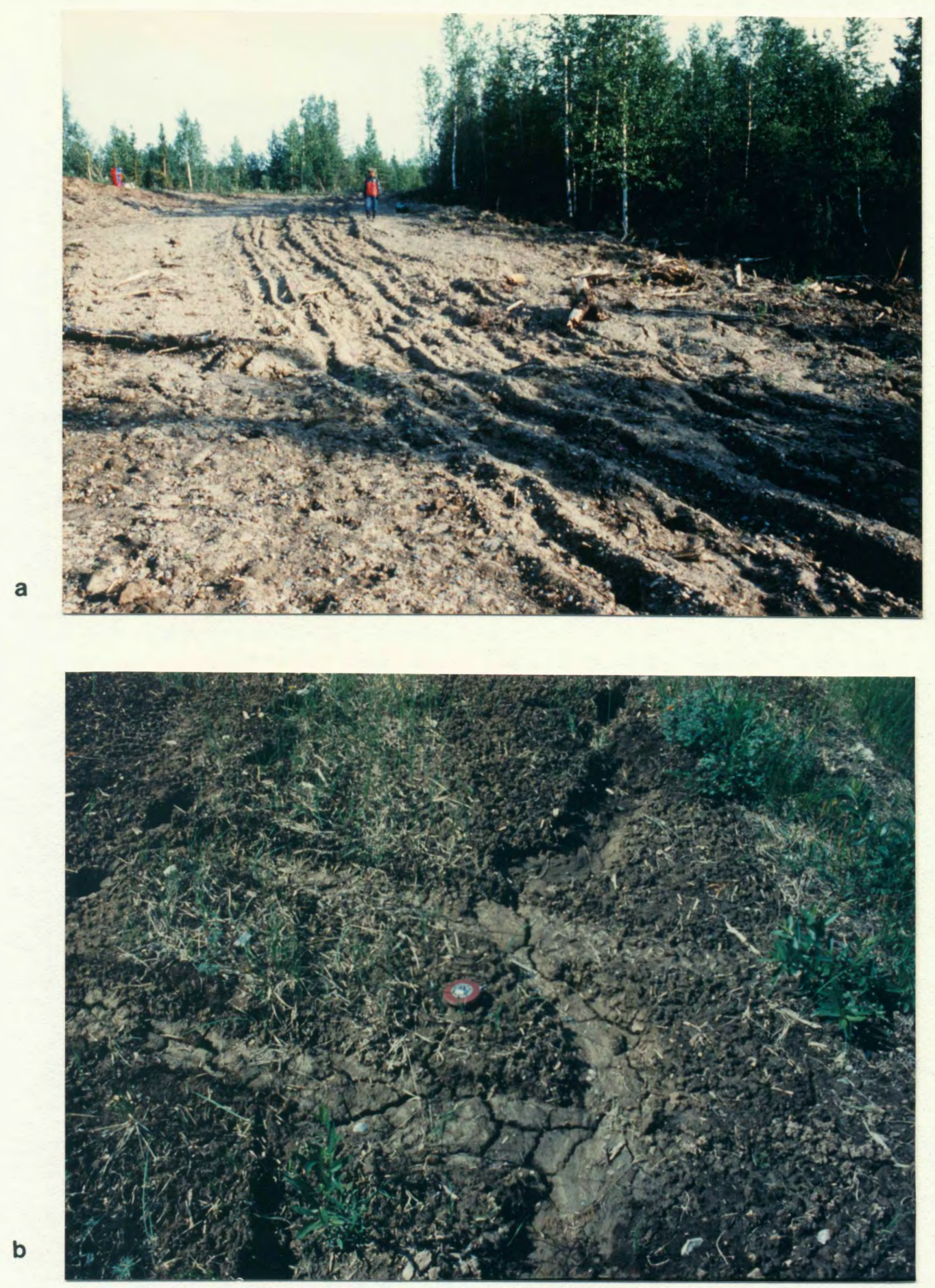

Figure 13. Surface rutting. a) on a sloping roadway section $\left(4^{\circ}\right)$, constructed by "cut -and - fill" practices in glaciofluvial gravels during the previous winter. The rutting was due to passage of vehicles too late in the spring (Site \#2); b) hydraulic erosion caused by the unseasonal passage of All-Terrain-Vehicles on the right-of-way (Site \# 1). Note the frothy appearance of the soil as a result of needle-ice formation. 


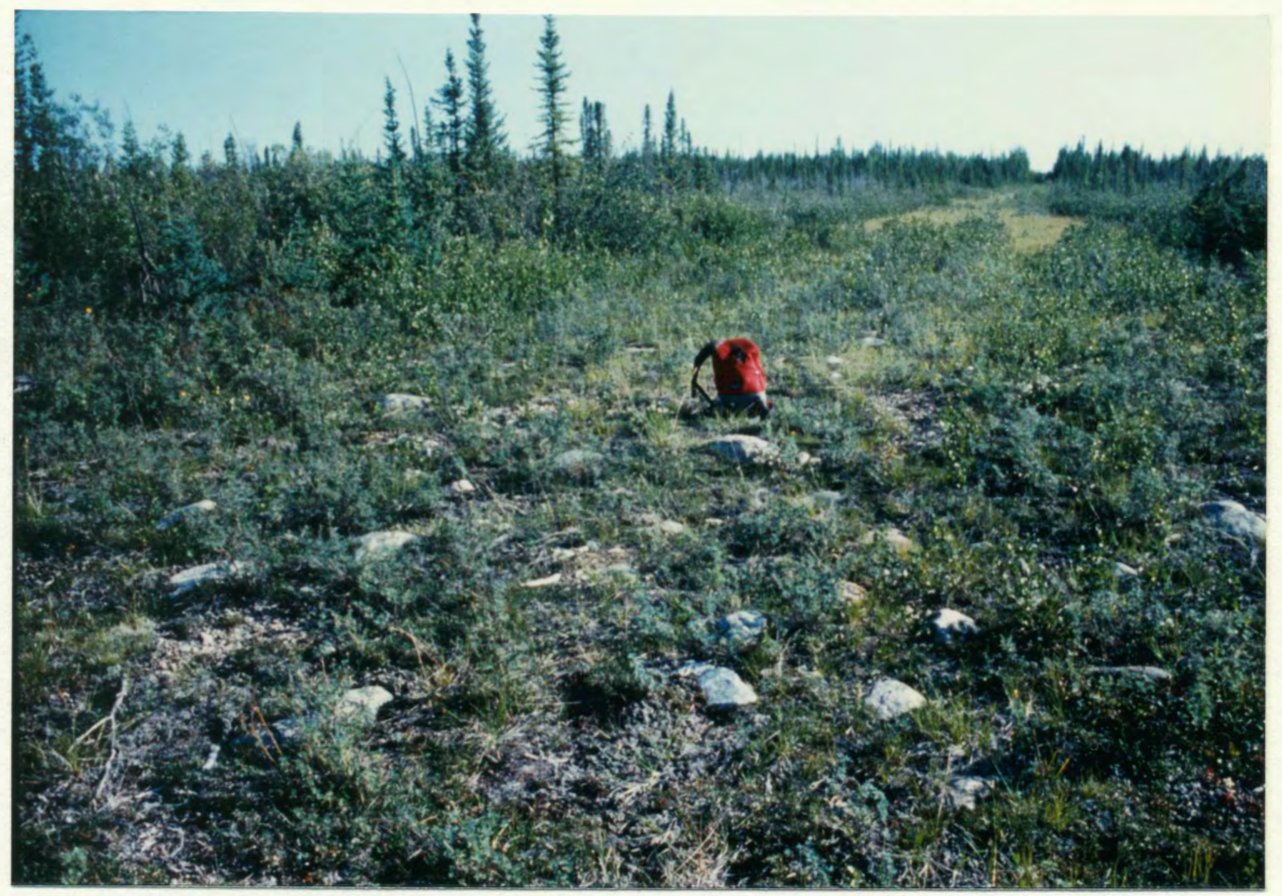

Figure 14. Unearthed rocks on a roadway underlain by coarse ground moraine (Site \# 4). 


\section{BOTANICAL CHARACTERISTICS AND REVEGETATION ON RIGHT-OF-WAYS}

Species composition, pattern and rate of natural revegetation of the investigated winter road right-of-ways varies with site characteristics, severity of of the disturbance, and the length of time since impact (Appendix D). On actively used right-of-ways, as well as those abandoned, species richness and diversity are lower than in the adjacent control.

The most apparent change in vegetation with regard to permafrost and ground ice is the extensive elimination of mosses and lichens on winter roads compared to the adjacent control (Table IX). Acrocarpous moss species reestablish at inconspicuous cover values on some of the abandoned roadways; however, Sphagnum and feathermosses remain largely absent. Fruticose and foliose lichens, abundant forms in local plant communities, are observed on right-of-ways only at Sites \# 6 (Little Chicago) and \# 9 (Campbell Creek). However, these are present at notably reduced cover values, compared to the adjacent controls. Both roadway sections have been abandoned for 15 years and it is uncertain whether the lichens (unidentified species and Peltighera aphthosa) survived the disturbance in the protected depressions between earth hummocks, or if recolonization occurred.

Plant communities and individual vascular plant species vary in their response to disturbance (Table IX). Though the investigated roadways show marked differences in site characteristics and disturbance history, a number of 
TABLE IX

\section{GROUND COVER (\%) OF VEGETATION STRUCTURE CLASSES ON ROADWAYS (WR) AND IN THE ADJACENT CONTROL SECTIONS (CO)}

\begin{tabular}{|c|c|c|c|c|c|c|c|c|c|c|}
\hline \multirow[t]{3}{*}{ \# } & \multirow[t]{3}{*}{ Site } & \multirow[t]{3}{*}{ Transect } & \multirow{2}{*}{\multicolumn{2}{|c|}{\begin{tabular}{|l} 
Deciduous \\
Shrubs
\end{tabular}}} & \multirow{2}{*}{\multicolumn{2}{|c|}{\begin{tabular}{|l|} 
Evergreen \\
Shrubs \\
\end{tabular}}} & \multirow{2}{*}{\multicolumn{2}{|c|}{\begin{tabular}{|l|} 
Grasses \\
\& Sodges \\
\end{tabular}}} & \multicolumn{2}{|c|}{ Mosses } \\
\hline & & & & & & & & & \multirow[b]{2}{*}{ WR } & \multirow[b]{2}{*}{$\infty$} \\
\hline & & & WR & $\infty$ & WR & $\infty$ & WR & $\infty$ & & \\
\hline & & & & & & & & & & \\
\hline \multirow[t]{5}{*}{1} & Canyon Creek & 1 & 14 & 40 & - & 30 & 27 & - & - & 15 \\
\hline & & 2 & 11 & 44 & - & 25 & 55 & 8 & . & 8 \\
\hline & & 3 & 3 & 24 & . & 15 & 54 & 15 & $<1$ & 25 \\
\hline & & 4 & 2 & 23 & - & 25 & 40 & 3 & - & 22 \\
\hline & & & & & & & & & & \\
\hline \multirow[t]{4}{*}{2} & Oscar Creek & 1 & $<1$ & 26 & $<1$ & 30 & 1 & - & - & 40 \\
\hline & & 2 & 5 & 105 & - & 10 & 70 & $<1$ & 5 & - \\
\hline & & 3 & 2 & 13 & + & 5 & 3 & - & 4 & 7 \\
\hline & & & & & & & & . & & \\
\hline \multirow[t]{4}{*}{3} & Jacktlsh Croek & 1 & $\leq 1$ & 25 & - & 50 & 70 & - & 60 & 10 \\
\hline & & 2 & 6 & 57 & - & 27 & 10 & - & 10 & 95 \\
\hline & & 3 & 6 & $12+$ & - & 12 & 60 & 60 & 9 & 77 \\
\hline & & & & & & & & & & \\
\hline \multirow[t]{5}{*}{4} & Hare Indlan River & 1 & 15 & 43 & - & 58 & - & - & - & - \\
\hline & & 2 & 7 & 24 & 42 & 35 & 21 & 4 & . & $\cdot$ \\
\hline & & 3 & 5 & 11 & - & - & 5 & 28 & 100 & 98 \\
\hline & & 4 & 5 & 31 & 5 & 41 & $<1$ & - & - & 25 \\
\hline & & & & & & & & & & \\
\hline \multirow[t]{4}{*}{5} & Tleda River & 1 & 27 & 35 & 10 & 27 & 25 & . & - & 20 \\
\hline & & 2 & 40 & 23 & 10 & 14 & 32 & 12 & - & $\cdot$ \\
\hline & & 6 & 45 & - & $<1$ & 26 & 4 & - & - & 30 \\
\hline & & & & & & & & & & \\
\hline \multirow[t]{5}{*}{6} & Little Chicago & 1 & 47 & 45 & 10 & 28 & 10 & $<1$ & - & 10 \\
\hline & & 2 & 35 & 31 & 1 & 30 & 35 & 15 & $\cdot$ & 15 \\
\hline & & 3 & 60 & 70 & 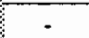 & - & 25 & 15 & 3 & 3 \\
\hline & & 4 & 59 & 65 & $<1$ & 16 & 30 & . & . & 44 \\
\hline & & & & & & & & & & \\
\hline \multirow[t]{5}{*}{7} & Charrue River & 1 & 57 & 31 & 3 & . & 25 & $<1$ & 2 & 15 \\
\hline & & 2 & 4 & 22 & - & 3 & 60 & . & 4 & - \\
\hline & & 3 & 11 & - & - & . & 45 & - & 5 & 5 \\
\hline & & 4 & - & $<1$ & - & - & 65 & 1 & 3 & 10 \\
\hline & & & & & & & & & & \\
\hline \multirow[t]{6}{*}{8} & Mackenzle H'way & 1 & 56 & 11 & 1 & 30 & 26 & $<1$ & - & 2 \\
\hline & & 2 & 77 & 95 & $<1$ & 45 & 13 & $<1$ & 7 & 7 \\
\hline & & 3 & 3 & 80 & - & 35 & 97 & $<2$ & - & - \\
\hline & & 4 & 30 & 31 & $<1$ & 37 & 62 & - & - & 12 \\
\hline & & 5 & 11 & 6 & 2 & 70 & 3 & - & 49 & 16 \\
\hline & & & & & & & & & & \\
\hline \multirow[t]{4}{*}{9} & Campbell Creek & 1 &. & 45 & - & 47 & 75 & 3 & $\therefore$ & 6 \\
\hline & & 2 & 45 & 85 & 1 & 50 & $17+$ & 4 & 5 & 5 \\
\hline & & 3 & 86 & 80 & 2 & 25 & 11 & 10 & 5 & 4 \\
\hline & & & & & & & & & & \\
\hline
\end{tabular}


regionally successful colonizers, as well as highly sensitive species have been recognized. Woody plants are the most severely impacted. Deciduous shrubs show significant reduction in cover on the three actively used roadways (Sites \# $1,2,3)$, but exhibit high recovery potential along the sides of currently used right-of-ways and those that have been abandoned. Species rarely found on disturbed surfaces, yet, abundant in the control sites, include Arctostaphylos spp., Rhododendron lapponicum, Sheperdia canadensis and Vaccinium spp. Evergreen shrubs are largely absent from roadways, even after 10 years of abandonment (Table IX). However, one exception is the mat-forming shrub mountain avens (Dryas integrifolia), which successfully colonizes dry and mesic corridor sections at Site 4, 5 and 6 (Appendix D).

Herbaceous species are generally present but relatively unimportant in the cover of most undisturbed vegetation associations. Most forbs have reestablished on abandoned roadways at cover values less or comparable to the controls'; successful species include, Aster sp., Potentilla spp., Senecio sp., Solidago sp. The horsetail Equisetum arvense proliferates on mesic right-of-ways. Fireweed (Epilobium angustifolium), an important pioneer on recently burned areas, rarely occurs on roadways that have been in continuous winter operation, and is, apparently, an inadequate competitor with opportunistic grasses and sedges.

Grasses and sedges constitute the most conspicuous element of the vegetation on abandoned and, particularly, actively used right-of-ways 
(Figure 15a). Sedges (Carex spp.) and Cottongrass (Eriophorum angustifolium) proliferate on wet roadway surfaces (Figure 15b). Arctagrostis latifolia, Calamagrostis canadensis, Poa spp., and in some localized sites, Juncus spp., are dominant ruderal species colonizing exposed mineral soil on dry and mesic sites. However, hummock tops and bare peat, generally poor seedbeds because of summer drought, remain sparsely vegetated even on roadways which have been abandoned for more than 10 years. The degree to which initial plant reestablishment is successful appears to be related to the moisture regime. Wet spots, though supporting fewer species, generally display higher live plant cover than dry or mesic sites with similar disturbance history. Where water has been deeply impounded as a result of thaw settlement, revegetation is limited and seems to depend primarily on the seeds and other propagules of wetland, pond or riparian species that are transported to these sites.

Abandoned right-of-ways display recolonization by plant associations of various successional stages, depending on the time since abandonment of the roadway and site characteristics. Pioneer graminoid communities, found on the three actively used roadways (Sites \# 1,2 \& 3), are generally replaced after less than 10 years following roadway abandonment by tall shrub associations; e.g. willows (Salix spp.), alder (Alnus crispa), paper birch (Betula papyrifera) and poplar (Populus spp.)(Figure 16). At this stage in succession, inconspicuous numbers of regenerating spruce (Picea spp.) and larch (Larix laricina) are 


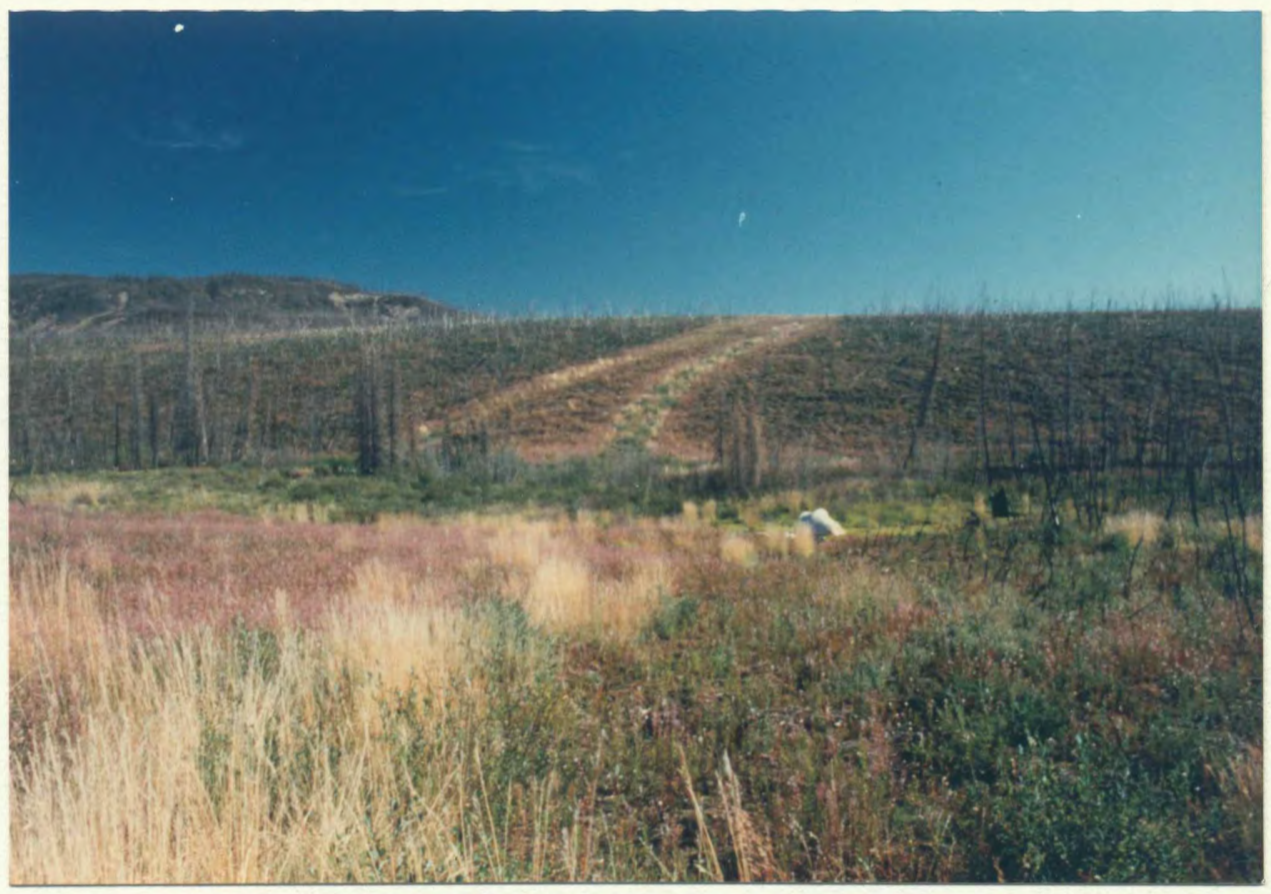

b

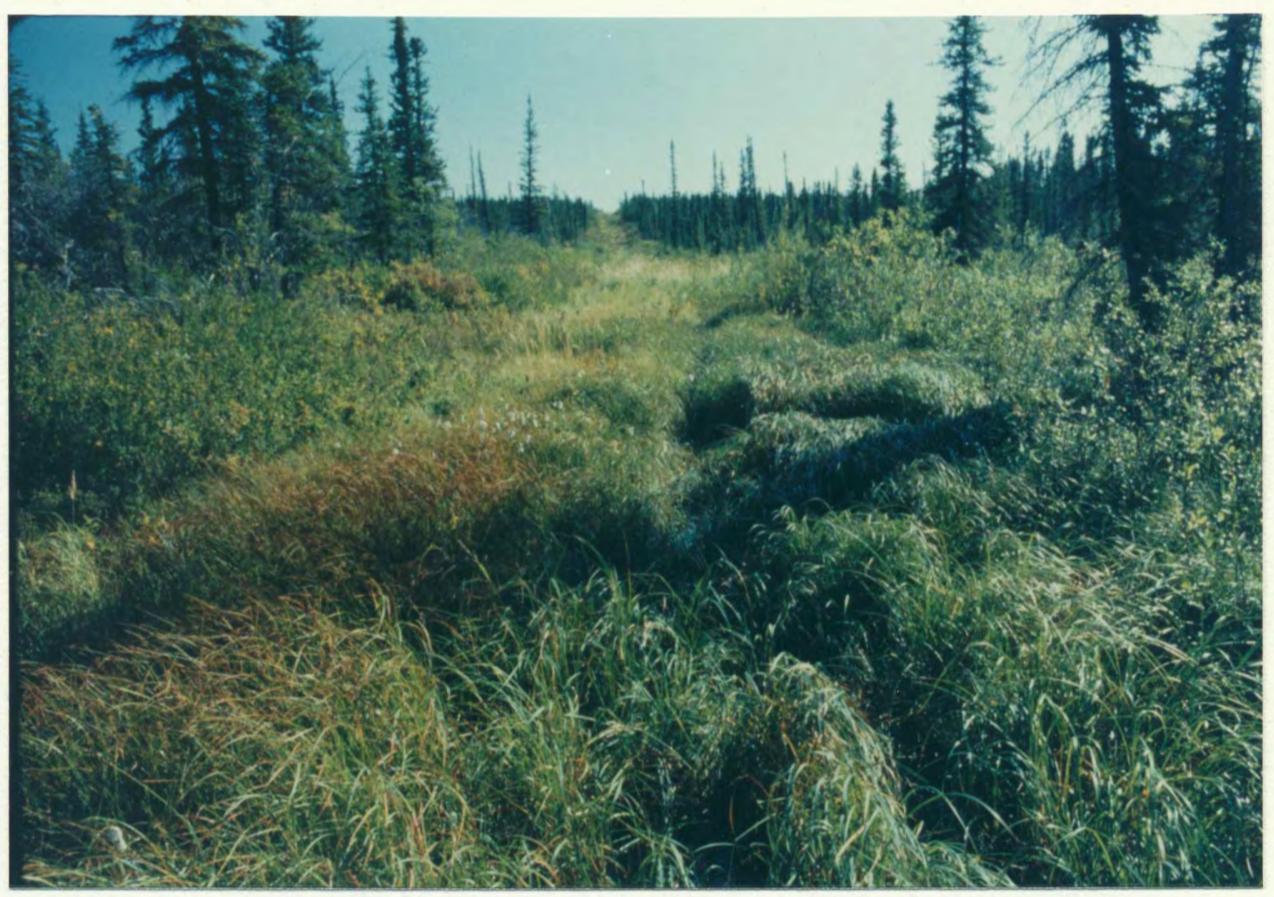

Figure 15. Dominance of grasses and sedges on roadways. a) on a winter road (right trail) and a seismic line (left trail) through a recent burn (less than two years before the field visit) dominated by fireweed (Epilobium angustifolium). The roadway has been abandoned for 14 years. The tent is pitched on a plain in the valley bottom formed by sediments eroded from the right-of-way (Site \#7). b) vigorous growth of cottongrass (Eriophorum angustifolium) on a subsided right-of-way which has been abandoned for 10 years (Site \# 8). 


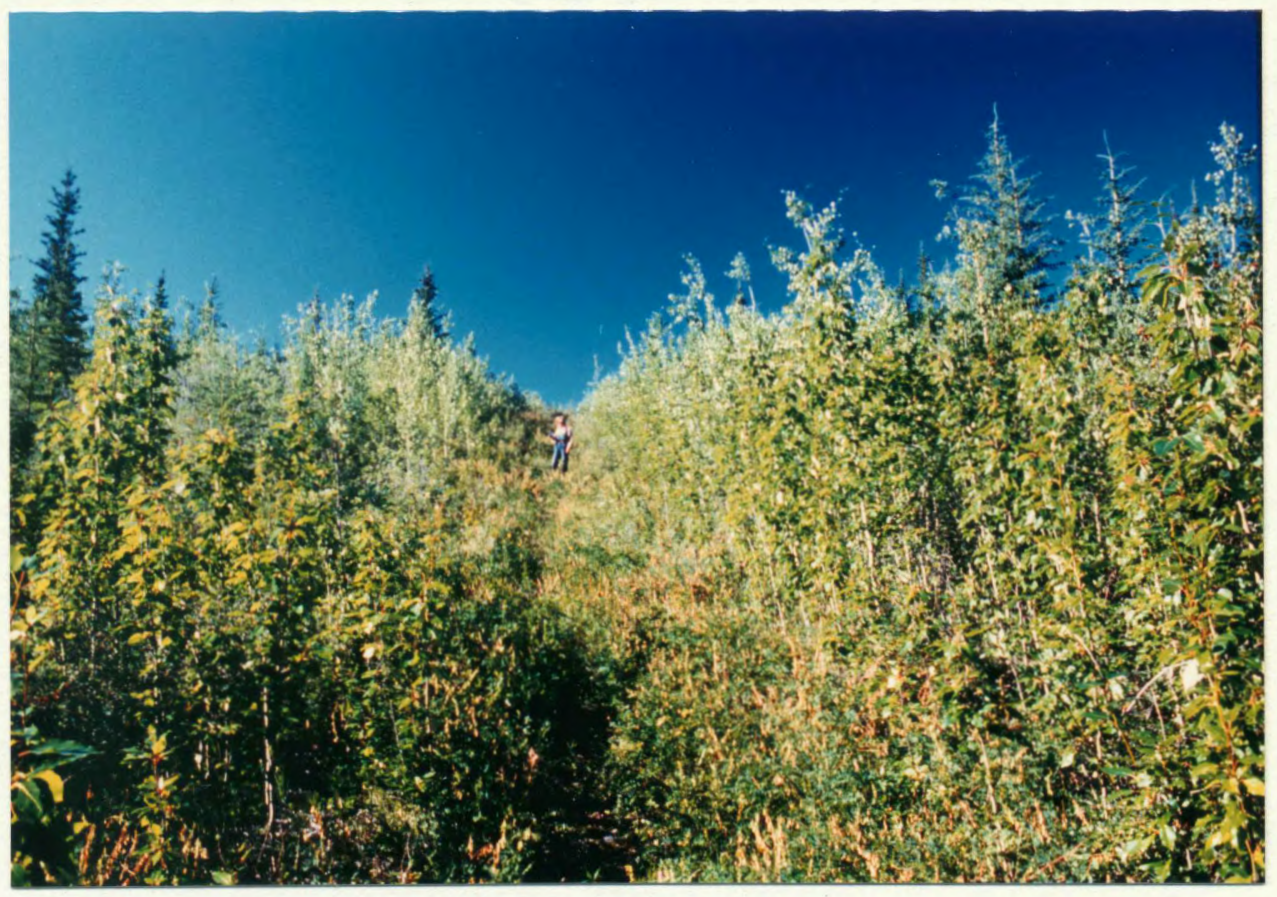

Figure 16. Tall shrub association on an inclined, south-facing right-of-way. The former roadside is indicated by tall spruce trees. Principal successionary species on the roadway after 17 years of abanonment include: Populus spp., Salix glauca, Sheperdia canadensis (Site \# 4). 
observed on warm and dry right-of-ways. Water-saturated roadway sections, exhibiting a high short-term recovery potential, advance at slower rates in succession than dry and mesic roadways. Reestablishment of spruce is less successful on wet sites where apparent competition by grasses and sedges is more vigorous.

White spruce (Picea glauca) exhibits an exceptional recolonization mechanism at Site \# 5 where seedlings vigorously encroach on a right-of-way bulldozed across a steep colluvium slope (Figure 17). The regenerating trees, measuring up to $1.50 \mathrm{~m}$ in height, exhibit significantly higher densities on the roadway and in gravel borrow pits than on the control site, suggesting an enhancement of the habitat by these disturbances. This may be attributed to increased availability of base nutrients on the roadway where calcareous scree material has been crushed. Additionally, white spruce seedlings are highly drought-resistant, giving them an important advantage over other species in the colonization of these habitats.

Tall shrub associations are eventually replaced by mixed wood communities with a sparse dwarf shrub understory and an incomplete ground cover of forbs and litter. These are observed on roadways with southfacing slopes which have been abandoned for at least fifteen years. In the localized tall shrub communities live plant cover values are comparable to, or in excess of the cover values among the control sites, primarily as a result of vigorous growth 


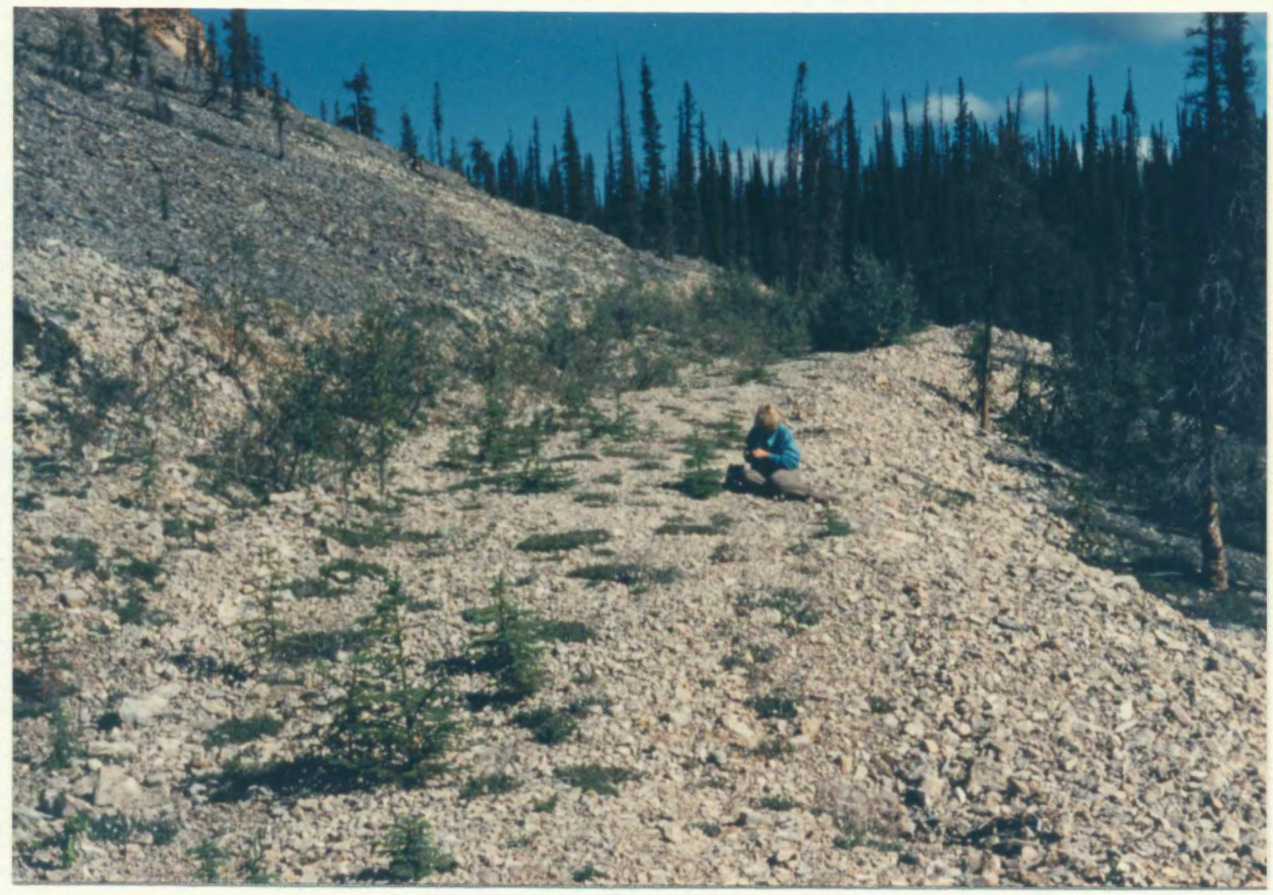

Figure 17. Encroachment of white spruce (Picea glauca) and mountain avens (Dryas integrifolia) on a right-of-way across a stabilized colluvium slope. Salix spp. proliferate on the upslope roadside. The roadway has been abandoned for approximately 17 years. 
among shrubby canopy species (Appendix D, Site \# 4, Transect 1, 2).

Vegetative ground cover is incomplete on all but wet roadway surfaces regardless of the age of the disturbance. Mineral soil or rocks are exposed in $70 \%$ of the plots on currently used right-of-ways and $60 \%$ on abandoned ones, respectively, compared to $21 \%$ of the plots in control sections. It should be noted that four of the six sites on abandoned roadways include plots on sparsely vegetated colluvium (Site \# 5) and sections of recently burnt forest in terrain of hummocky microrelief. Thus, analysis of the figures provided for the revegetating, abandoned roadways and control sections must take these conditions into consideration to account for the inflated percentages. On transects where mineral soil is exposed, its cover is increased on $86 \%$ of the right-of-ways compared to the control sites. Furthermore, bare ground (litter, rocks and exposed soil) on roadways is increased on $70 \%$ of the investigated transects relative to the adjacent controls. 


\section{CHAPTER VI}

\section{TERRAIN DISTURBANCES -- IMPLICATIONS TO THE ENVIRONMENT}

This chapter integrates information presented in the previous chapter by discussing speculative energy budget changes following terrain disturbances inferred from observations on changes in microclimate and permafrost. The impacts of winter road operation on permafrost are evaluated with respect to findings from previous experimental impact assessments. Finally, the effects of changes in microclimate and permafrost are related to disturbed vegetation and its recovery potential.

\section{ENERGY BUDGET CHANGES ON DISTURBED TERRAIN}

Little attention has been directed to changes in the energy budget following man-induced or natural vegetation disturbances in Subarctic forests (Beattie et al., 1973; Haag and Bliss, 1974; Rouse and Kershaw, 1971; Rouse, 1976). The following discussion is a speculative analysis based on the data collected for the field study. The removal of the tree and shrub strata on rightof-ways results in the change from a three- to a two-dimensional energy absorbing system and, consequently, a repartitioning of the individual energy budget components (Haag and Bliss, 1974). The microclimatic changes 
presented in Chapter V suggest a decrease in net radiation on currently used and abandoned, revegetating right-of-ways. The reflectivity of the ground surface increases following vegetation clearing. Furthermore, greater receipt of solar radiation on disturbed sites results in higher surface temperatures. Therefore, increased emittance of longwave radiation from roadway surfaces can be expected. Terrestrial radiation losses increase on upland sites, exhibiting substantial soil heating due to summer drought. In the adjacent forest, longwave radiation losses are considerably smaller due to a lower radiant heat load at the ground surface, and the conditioning effect of the organic mat on the mean surface temperature. Moreover, the canopy absorbs and retains much of the heat lost from the surface. This "buffer" effect of the tree canopy can be demonstrated by a sharper drop in air temperatures, and stronger temperature inversions on right-of-ways than in the forest during calm and clear summer nights.

Additional observations indicate that the partitioning of the subsurface heat flux, latent heat and sensible heat, respectively, is controlled predominantly by the sites' moisture regime. Roadway sites, maintaining a high moisture regime throughout the thaw period, exhibit lower sensible heat flux than dry sites, indicating that a substantially greater portion of the ground heat flux is realized through latent heat loss by evaporation of soil water, and only a very limited portion through sensible heat flow. This explains why, following 
disturbance, continuously wet soils in depressional areas and fenlands experience only moderate warming and relatively small increases in thaw depth. Conversely, upland soils, although exhibiting high moisture contents immediately following snowmelt, are generally depleted of surface-soil water by high evaporative losses early in the summer (Haag and Bliss, 1974). By mid-summer, the droughty substrate exhibits a high resistance to further evaporation, and latent heat loss. Therefore, the cardinal portion of the available energy at the ground surface is converted into sensible heat. This scenario may explain the profound surface and soil warming and, therefore, the significant increases in active layer depth at dry upland sites.

Several assumptions can be made about energy budget changes during winter. Owing to little snow accumulation and snow densification on the windswept roadway surfaces (Kershaw, unpublished data), the soils here would experience faster ground freezing at the onset of winter than the adjacent forest soils. This would be true even considering that heat storage during the thaw period is significantly greater in roadway soils than in adjacent forest soils, because the sensible heat, stored in roadway soils, is lost through conduction at a substantially faster rate than the latent heat, released in the forest soils through evaporation (Rouse, 1984). Nevertheless, roadway sections with high soil moisture content in early winter would benefit from a prolonged zero curtain effect, as a result of substantial latent heat release. Consequently, they 
would be expected to freeze later than dry upland right-of-ways. By contrast, upland forest soils retain considerably more soil moisture at freeze back, therefore, ground freezing is delayed by the release of substantial amounts of latent heat (Rouse, 1984). Furthermore, heat losses are effectively inhibited by the organic mat, a deep snow blanket, and the vegetation canopy (Rouse, 1984).

\section{PERMAFROST DEGRADATION}

Short-term observations of environmental impacts on winter road test sites in the Mackenzie River Valley during the early 1970s implied that the degradation of near-surface permafrost was inconsequential (Canadian Arctic Gas Study Ltd., 1974a; Adam and Hernandez, 1977; Younkin and Hettinger, 1978). Following one season of experimental snow and ice road operations at Inuvik, N.W.T., and Norman Wells, N.W.T., peat layers were largely preserved, although compacted. Increases in thaw depth within the subsequent 3 and 4 years were moderate (12\% and $68 \%$, respectively) (Brown and Grave, 1979). Thaw subsidence was negligible because neither of the two test facilities was constructed on excessively ice-rich sediments despite their widespread occurrence in the area (Hughes et al., 1973). At the Norman Wells test loop, snow and ice road construction commenced in March when much of the annual snowfall had accumulated (Adam and Hernandez, 1977). Yet, the critical period for snow road construction would be in early winter when the snow cover is scant and the 
ground may not be entirely frozen. At the Inuvik test site inadequate snowfall delayed the construction of an 800 m-long processed snow road until early December when $7,500 \mathrm{~m}^{3}$ of snow were harvested on a nearby lake and hauled in over a gravel road (Younkin and Hettinger, 1978). However, suitable harvest sources are scarce along the Mackenzie River Valley, and it is likely that snow could not be procured in adequate quantities in years with little snowfall. Since a shortage of snow in the Lower Mackenzie River Valley occurs one out of five years (Adam and Hernandez, 1977), it seems apparent that winter roads would have to be operated periodically under conditions less than optimal. While N.W.T. land use permits require a minimum of $5 \mathrm{~cm}$ of snow cover for winter road construction and operation, Felix and Raynolds (1989a) report less than 25 $\mathrm{cm}$ of snow to be insufficient to protect the ground surface on winter trails used by seismic exploration crews. A snow cover of even greater depth may be required for snow road construction on terrain with hummocky microrelief to allow for packing of snow in the inter-mound depressions (Zoltai, 1975).

Winter road-induced terrain disturbances were inadequately simulated by the temporary snow and ice road tests at Norman Wells and Inuvik (Adam and Hernandez, 1977; Younkin and Hettinger, 1978). The findings of this study, presented in Chapter V, indicate that perennial winter road operation inevitably results in the removal of the organic mat (moss and peat layers). Mean increases in thaw depth at the investigated sites along the Lower and Central 
Mackenzie River Valley are substantially greater (105\%) than those reported from the Norman Wells and Inuvik test facilities (68\% and $12 \%$, respectively) (Adam and Hernandez, 1977; Younkin and Hettinger, 1978). Thaw equilibrium, following one season of winter road operation, was attained at the Inuvik test loop and the Norman Wells test site after three, and four years, respectively (Brown and Grave, 1979). However, the observations on long-term disturbances in this research, presented in Chapter $\mathrm{V}$, suggest that longer time periods are necessary for thermal equilibration on perennially used winter road corridors. This is due to deeper thaw, gradual impact aggregation, and decreased terrain stability in ice-rich sediments as a consequence of, localized, substantial ground subsidence.

It is noteworthy, that physical terrain modifications have not spread laterally beyond the area of initial disturbance. Thermokarst slumping, flow slides and slope failures, degradational processes which have been reported following snow pad operations at several sites on the Alaskan North Slope (Everett, 1985; Lawson, 1986), have not occurred on the investigated sites, although they may have a localized occurrence.

The variable effects of removal and compaction of the vegetation, the organic mat, and localized soil layers on near-surface permafrost indicate the relative importance of terrain characteristics and sediment properties at the investigated sites rather than the influence of a latitudinal gradient. The primary 
factors determining the nature and extent of the terrain response appear to be ice content of the substrate which increases with the amount of fines, dimensions and distribution of ground ice, and the geotechnical attributes of the sediments. Furthermore, comparison of the severity of impacts on the permafrost across the study sites implies a correlation with the level of disturbance, i.e. type of winter road, types of vehicles, traffic volumes, and duration of right-of-way use; however, this association could not be assessed in adequate detail. Observations on perennially operative winter roads suggest that the removal of the vegetation and surface organic or mineral deposits results in permanent terrain modification due to near-surface permafrost degradation. Pre-disturbance permafrost conditions can apparently only be attained with the reestablishment of the organic mat. However, Zoltai and Pettapiece (1974) found that following fire, the permafrost table in hummocky terrain began to rise 60 to 80 years after the establishment of trees, but the organic mat would require at least 150 years to develop its original thickness.

\section{VEGETATION -- IMPACT AND RECOVERY}

Disagreements persist relative to rates and pattern of recovery in disturbed permafrost-affected ecosystems. Human-induced disturbance is generally considered to be environmentally destructive, although in some instances, depending upon the researcher's orientation, it can be argued that a 
more biologically productive or diverse ecosystem may result (Walker et al., 1987). Viereck (1973) noted that forested areas in the lower elevations of Alaskan taiga, if repeatedly burned, occasionally developed into meadowlands dominated by grass-likes, prickly rose (Rosa acicularis), and herbaceous species. Gill (1973) found that the production of a more severe post-disturbance microclimate associated with vegetation removal resulted in the conversion of Subarctic open-woodland to physiognomically simpler treeless tundra associations. Conversely, Chapin and Shaver (1981) argued that energy budget changes following surface disturbance on wet sedge tundra improved the permafrostaffected soil environment for plant growth, e.g. higher soil temperatures and increased rooting depths, increased nutrient availability, extension of the growing seasons. Accordingly, Strang (1973), and Pettapiece and Zoltai (1974) predicted increased tree productivity and rates of tree regeneration following man-induced disturbance in the forested areas of the Mackenzie River Valley. Moreover, Strang (1973) implied that fire in the forest-tundra ecotone stimulated more vigorous tree stands, whereas a freedom from burning promoted the development of a stagnating, "drunken" forest, and eventually its replacement by a treeless lichen tundra.

The data on changes in microclimate and permafrost, presented and analyzed in Chapter V, suggest enhanced recolonization conditions on wet (lowland) roadways, but aggravated revegetation conditions on dry (upland) 
roadways. Summer drought and diurnal temperature extremes adversely affect the regenerating vegetation on upland right-of-ways, though increased soil temperatures, deeper rooting zones, extended growing seasons, and photosynthetic advantages on the disturbed surfaces result in environmental enhancement. Radiation frost, and frequent needle ice events may further inhibit seedling survival.

The soil climate of wet (lowland) right-of-ways is far more buffered and is not subjected to the thermal extremes experienced on disturbed upland terrain; moreover, the subsurface flow of water on wet roadways enhances plant nutrient cycling (Chapin et al., 1988). At the onset of winter, upland right-of-ways freeze earlier than their lowland counterparts; consequently, colder soil temperatures further reduce the germination potential of seeds and seedling survival. Increased wind speeds over roadways are more likely to generate frost drought conditions on frozen upland sites than on unfrozen wet lowland sites, which still have sufficient moisture to drive transpiration in early winter before snow protects the roadway vegetation.

It seems reasonable to assume that the potential for revegetation following winter road operation varies with severity of the impact. On temporarily used right-of-ways, revegetation has been reported to occur almost immediately following disturbance by vegetative regrowth (Adam and Hernandez, 1977; Younkin and Hettinger, 1978). Conversely, the observations on long-term 
disturbances, presented in Chapter V, imply that revegetation on currently used right-of-ways depends primarily on seed-producing plants, particularly, grasses and sedges. On actively used right-of-ways, vegetative regrowth, following destruction of above ground plant shoots, appears to be limited due to the gradual depletion of root carbohydrate reserves. However, Salix arbusculoides, an upland willow highly adapted for resprouting following disturbance (Kershaw et al., 1988), is the single exception which exhibites continued regeneration from root reserves on a roadway which had been perennially in operation for at least 17 years.

Perennial winter road operations on upland terrain causes the eradication of shrubs, apparently as a result of the destruction of near-surface rootstocks and vegetative propagules (Figure 18). This corresponds with observations by Ironside (1974), who noted that the woody roots and runners of shrubs (i.e. Salix spp., Ledum spp., Vaccinium spp.) are brittle when frozen and, being located near the surface, are fractured and torn by the pressure of passing vehicles over upland tundra. Furthermore, he found that the roots of most grasses and sedges remain relatively flexible when frozen, therefore, are less susceptible to damage. Crushing of the plants' rootsystems appeared to be significantly reduced on wet lowland sites, where the water-saturated substrate freezes solid during winter and compacts less than on upland sites.

Recolonization by vegetative means becomes important once the 


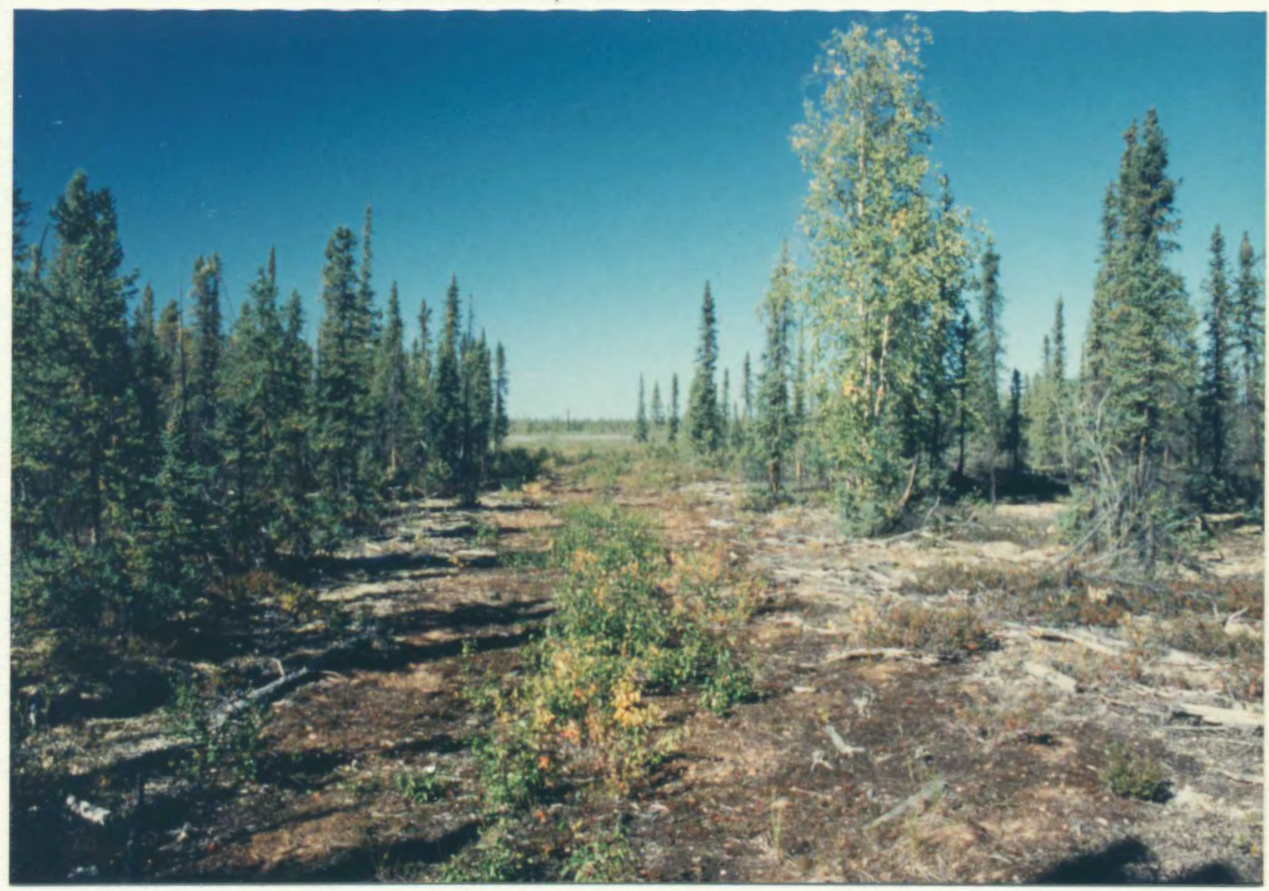

Figure 18. Roadway illustrating the general absence of vegetation, particularly shrubs, in the track areas after 10 years of abandonment. This is attributed to the destruction of near-surface rootstocks and vegetative propagules. Trees in the adjacent control average $3.5 \mathrm{~m}$ in height (Site \# 8). 
disturbance is discontinued and the terrain has stabilized. Asexually reproducing species advance slowly into the abandoned right-of-ways from the road shoulder. However, species, with both reproductive adaptations; those producing windborne seeds and propagating vegetatively (i.e. Salix spp., Populus spp., Betula glandulosa, Dryas spp., Eriophorum spp.), appear to be the most successful in reoccupying abandoned winter road right-of-ways. Conversely, species, producing heavy seeds or fruits, are dispersed very slowly. This may explain the absence of most evergreen shrubs from long abandoned right-of-ways. From these findings, it can be reasonably speculated that the reproductive mechanisms of individual plant species are important factors influencing the successionary patterns and rates of growth for discreet communities. One would expect regeneration of vegetation to be impeded with increasing latitude, due to increasing environmental severity. 


\section{CHAPTER VII}

\section{SUMMARY AND CONCLUSIONS}

Winter road operations in terrain underlain by permafrost generate a sequence of ecological consequences. This research, conducted in the Lower and Central Mackenzie River Valley, N.W.T., Canada, was concerned with longterm impacts on terrain morphology, microclimate, permafrost, soils, and vegetation. Changes in these ecological parameters were assessed in a variety of environmental settings along a latitudinal gradient from $65^{\circ} \mathrm{N}$ to $68^{\circ} \mathrm{N}$, to provide a regional perspective on the potential and pattern for ecosystem recovery. An additional purpose of this research was to determine if conclusions, developed in the early 1970 s regarding the disturbance and recovery of winter road rights-ofway, are still valid (Adam and Hernandez, 1977; Younkin and Hettinger, 1978).

Terrain disturbances by winter road operations are largely due to the removal of the vegetation during right-of-way clearing and the resulting alterations in the surface energy regime. However, the actual extent to which key components of the ecosystem respond to surface perturbations appears to be determined by the thickness of the insulative organic mat.

Vegetation clearing produces greater receipt of solar radiation at the soil surface, which leads to increases in mean daily air and surface temperatures and 
in their diurnal variations. These effects slightly diminish with increasing latitude due to progressively sparser vegetation cover. As a result of enhanced energy penetration to the disturbed ground surface, heat exchange in the substrate increased in diurnal range. During the measurement periods, heat storage in roadway soils were increased compared to undisturbed sites. However, wet lowland soils experience less sensible heating than dry upland soils owing to increased evaporative losses.

Near-surface permafrost degrades on roadways as a result of higher soil temperatures. Mean increases in thaw depth on winter roads used for a number of years are significantly greater than has previously been reported from temporary winter road test sites in the area (Adam and Hernandez, 1977; Younkin and Hettinger, 1978). The variable effects of winter road operation on near-surface permafrost, monitored across sites in diverse environmental settings, indicate the relative importance of terrain characteristics and sediment properties rather than the influence of a latitudinal gradient. Increases in thaw depth are smaller at water-logged roadway sections (53\%) than on dry roadway sites (153\%), owing to reduced sensible heating of the former. Nature and extent of terrain response to deeper seasonal thaw are largely dependent upon the ice content of the substrate. Substantial ground settlement results where excessively ice-rich sediments thaw. Observations on terrain morphology at abandoned rights-of-way of varying disturbance ages indicate that these terrain modifications are enduring. 
Soil degradation in terms of scuffing of earth hummocks, stripping of soil layers, as well as surface rutting and erosion, is an inevitable consequence of perennial winter road operation on upland sites; however, these perturbations are limited in wet lowland terrain. The most substantial impact on the soil, with regard to the permafrost, soil climate, and vegetation, is the complete or partial removal of the organic mat on perennially used winter road rights-of-way, an observation which contrasts with conclusions developed on temporary winter road test sites in the Mackenzie Valley during the early 1970s (Adam and Hernandez, 1977; Younkin and Hettinger, 1978).

Plant communities adjust to continual surface disturbance with regard to their floristic composition. Species richness and diversity are lower on roadways than in the adjacent undisturbed terrain, reflecting decreased abundance of shrubs, particularly evergreens, and increased dominance by a few species of graminoids. The degree to which plant establishment on disturbed surfaces is successful, appears largely related to the moisture regime of a site. Recolonization conditions are enhanced on wet lowland roadways, owing to increased soil temperatures, deeper rooting zones, extended growing seasons, and photosynthetic advantages. However, on dry roadway surfaces, these beneficial consequences of disturbance, are counterbalanced by summer drought and temperature extremes, therefore, reducing the revegetation potential. 
The findings of this research indicate that surface perturbations from perennial winter road operations exceed disturbance levels predicted in the context of evaluations of short-term winter road performance and environmental impact assessments during the early 1970s (Adam and Hernandez, 1977; Younkin and Hettinger, 1978). However, the overall terrain impact by winter roads is smaller than disturbances caused by conventional all-weather roads. Wet lowland areas are less sensitive to winter road operations than dry upland sites and should be preferred for route selection although a late freezeup curtails the available period for winter road use. The success of winter roads in reducing terrain damage is, more than anything else, tied to their proper preparation and maintenance, and the prudent observance of operation schedules. 


\section{REFERENCES CITED}

Adam, K.M., 1974, "Impact from Winter Road Use and Misuse", in:

Environment Protection Board, Research Reports, Environmental Impact Assessment of the Portion of the Mackenzie Gas Pipeline from Alaska to Alberta, Winnipeg: Environment Protection Board, Vol. 4, pp. 29-36.

1978, Building and Operating Winter Roads in Canada and Alaska, Environmental Studies No. 4, Department of Indian and Northern Affairs, Ottawa.

, 1981, "Travel over Snow", in: Gray, D.M. and D.H. Male (eds.), Handbook of Snow, Principles, Processes, Management and Use, Toronto: Pergamon Press, pp. 521-561.

Adam, K.M. and H. Hernandez, 1977, "Snow and Ice Roads: Ability to support Traffic and Effects on Vegetation", Arctic, 30(1), pp. 132-27.

Adam, K.M., R.F. Pietrowski, J.M. Collins, and B.T. Silver, 1984, "Snow Roads for Pipeline Installation on the Arctic Pilot Project", in: Smith, Daniel W. (ed.), Proceedings, Third International Speciality Conference, Cold Regions Engineering "Northern Resources Development", April 4,5,6, 1984, Edmonton, Alberta, Vol. 2, Montreal, Canadian Society for Civil Engineering, pp. 603618.

Anonymous, 1974, "Environmental and Socio-Economic Effects of the Proposed Canadian Arctic Gas Pipeline on the Northwest Territories and Yukon", in: Pipeline Application Assessment Group, Mackenzie Valley Pipeline Assessment, Corrigendum, Ottawa: Department of Indian Affairs and Northern Development, pp. 233-237.

1975a, "Terrain Sensitivity, Mackenzie Valley and Northern Yukon", Environmental-Social Program, Northern Pipelines, Task Force on Northern Oil Development, 2 maps.

1975b, "Report on Geotechnical Investigation, Mile 725 to Mile 936, Mackenzie Highway", Vol. 1, Geotechnical Analysis, Canada, Public Works. 
1975c, "Report on Geotechnical Investigation Mile 725 to Mile 936, Mackenzie Highway", Vol. 5, Borehole Logs and Airphoto Mosaic; Mile 800 to Mile 835, Canada, Public Works.

Atmospheric Environment Service, 1982, "Canadian Climate Normals, Temperature and Precipitation", Environment Canada.

AVCON Aviation Consultants Ltd., 1976, "Historical Activity Data, Mackenzie Valley Corridor", (unpublished report).

Beattie, C.A., D. Erickson, A. Martin and D.M. Gray, 1973, "Energy Budget Studies in the Arctic over Areas subjected to Different Levels of Vehicular Activity - 1972-73", Task Force on Northern Oil Development, Report 72-23.

Benninghoff, W.S., 1966, "Relationships between Vegetation and Frost in Soils", Proceedings, Permafrost, International Conference, Washington D.C.: National Academy of Science, National Research Council, Publication 1287, pp. 9-13.

Berger, T.R., 1977,"Northern Frontier, Northern Homeland: The Report of the Mackenzie Valley Pipeline Inquiry", Vol. 1 \& 2, Ottawa: Supply and Services, Canada.

Berry, M.O., "Recent Temperature Trends in Canada", paper presented as part of the Annual Meeting of the Canadian Association of Geographers, Edmonton, Alberta, Canada, 29 May - 4 June 1990.

Bliss, L.C. and R.W. Wein, 1972, "Plant Community Responses to Disturbance in the Western Canadian Arctic", Canadian Journal of Botany, 50, pp. 10971099.

Bostock, H.S., 1965, "A Provisional Physiographic Map of Canada", Geological Survey of Canada, Paper 64-35.

, 1970, "Physiographic Subdivisions of Canada", in: Douglas, R.J.W. (ed.), Geology and Economic Minerals of Canada, Canada Geological Survey Economic Geology Report 1, pp. 9-30.

Brewer, R. and S. Pawluk, 1975, "Investigations of Some Soils Developed in Hummocks of the Canadian Subarctic and Southern Arctic Regions, I. Morphology and Micromorphology", Canadian Joumal of Soil Science, Vol. 55(3), pp. 301-319. 
Brown, J. and N.A. Grave, 1979, "Physical and Thermal Disturbance and Protection of Permafrost", U.S. Army Cold Regions Research and Engineering Laboratory, CREEL Special Report 79-5.

Brown, R.J.E., 1966, "Influence of Vegetation on Permafrost", Proceedings, Permfrost, International Conference, Washington D.C.: National Academy of Science, National Research Council, Publication 1287, pp. 20-25.

1967, "Permafrost in Canada", Geological Survey of Canada, Map 1246A.

, 1970, Permafrost in Canada, Toronto: University of Toronto Press, 234 p.

, 1978, "Permafrost", in: Hydrological Atlas of Canada, Ottawa, Canadian National Committee for the International Hydrological Decade, Ministry of Supply and Services, pl. 32.

Burns, B.M, 1973, "The Climate of the Mackenzie Valley-Beaufort Sea", Vol. 1 \& 2, Climatological Studies No. 24, Environment Canada, Ottawa.

Canadian Arctic Gas Study Ltd., 1974, Progress Report on CAGSL Revegetation Studies north of $60^{\circ} \mathrm{N}, 56 \mathrm{p}$.

Canadian Arctic Gas Pipeline Ltd., 1975, "Alignment Sheets 8B3, Pipeline Route in Canada, North of $60^{\circ}$ Latitude", Report prepared by Northern Engineering Services Company Ltd.

Canadian Petroleum Association, 1990, Arctic Petroleum Review, Vol. 12(2).

Chapin, F.S., N. Fetcher, K. Kielland, K.R. Everett, and A.E. Linkins, 1988, "Productivity and Nutrient Cycling of Alaskan Tundra: Enhancement by Flowing Soil Water", Ecology, Vol. 69(3), pp. 693-702.

Chapin, F.S. and G.R. Shaver, 1981, "Changes in Soil Properties and Vegetation following Disturbance of Alaskan Arctic Tundra", Journal of Applied Ecology, 18, pp. 605-617.

Christofferson, J., Winter Road Contractor, Norman Wells, Interview by author, 21 August 1989.

Cook, D.J. and J.D. Aitken, 1969, "Geology of Fort Good Hope", Geological Survey of Canada, Map 4-1969. 
Department of Public Works and Highways, 1988, "Winter Road Construction and Maintenance - Specifications", Work No. CT 88-9870, Yellowknife, N.W.T.

Douglas, R.J.W., H. Gabrielse, J.O. Wheeler, D.F. Stott, and H.R. Belyea, 1976, "Geology of Western Canada", in: Douglas, R.J.W. (ed.), Geology and Economic Minerals of Canada, Part B, Canada Department of Energy and Resources, pp. 365-488.

Environmental Protection Service, 1976, "Recommended Environmental

Standards for the Design and Construction of a Mackenzie Valley Gas Pipeline", Environment Canada.

Everett, K.R., B.M. Murray, D.F. Murray, A.W. Johnson, A.E. Linkins, and P.J. Webber, 1985, "Reconnaissance Observations of Long-Term Vegetation Recovery in the Cape Thompson Region, Alaska, and Additions to the Checklist of Flora", U.S. Army Cold Regions Research and Engineering Laboratory, Hanover, New Hampshire, CRREL Report 85-11, 76 p.

Expert Committee on Soil Survey, 1987, The Canadian System of Soil Classification, Agriculture Canada, Research Branch, Publication 1646, $164 \mathrm{p}$.

Felix, N.A. and M.K. Raynolds, 1989a, "The Role of Snow Cover in Limiting Surface Disturbance caused by Winter Seismic Exploration", Arctic, Vol. 42(1), pp. 62-68.

1989b, "The Effects of Winter Seimic Trails on Tundra Vegetation in Northeastern Alaska, U.S.A., Arctic and Alpine Research, Vol. 21(2), pp. 188-202.

Foothills Pipe Lines (Yukon) Ltd., 1979, "The Dempster Lateral Gas Pipeline Project", 3 Alignment Sheets.

Forest Management Institute, 1972, "Vegetation Types of the Lower Mackenzie and Yukon Corridor", Open File ESP, 104.

1973, "Vegetation Types of the Lower Mackenzie and Yukon Corridor", Appendix 7: Maps Showing Vegetation Types of the Mackenzie Valley. 
, 1974, "Vegetation Types of the Mackenzie Corridor", EnvironmentalSocial Program, Northern Pipelines, Task Force on Northern Oil Development, Report 73-46, 85 p.

1975, "Vegetation Types of the Lower Mackenzie and Yukon Corridor", Environmental-Social Program, Task Force on Northern Oil Development, Report No. 74-40. 73 p.

French, H.M., 1976, The Periglacial Environment, New York: Longman, 309 p.

Gill, D., 1973, "Ecological Modifications caused by the Removal of Tree and Shrub Canopies in the Mackenzie Delta", Arctic, 26, pp. 95-111.

Haag, R.W., 1973, "Energy Budget Changes following Surface Disturbance to two Northern Vegetation Types", in: Bliss, L.C. (ed.), Botanical Studies of Natural and Man-Modified Habitats in the Mackenzie Valley, Eastern Mackenzie Delta Region and the Arctic Islands, Task Force on Northern Oil Development, Report 73-43.

Haag, R.W. and L.C. Bliss, "Functional Effects of Vegetation on the Radiant Energy Budget of Boreal Forest", Canadian Geotechnical Journal, 11, pp. 374-379.

Hardy Associates (1978) Ltd., 1980, "Revegetation and Impact Assessment Studies in the Mackenzie River Region", unpublished report prepared for ESSO Resources Canada Ltd.

, 1984, "Land Use Guidelines; Access Roads and Trails", Ottawa: Department of Indian Affairs and Northern Development.

Harris, S.A, 1986, The Permafrost Environment, Totowa, New Jersey: Barnes \& Noble Books.

Heginbottom, J.A., 1974, "The Effects of Surface Disturbance on Ground Ice Content and Distribution", Geological Survey of Canada, Report of Activities, 74-1, Part A, p. 273.

Heginbottom, J.A. and P.J. Kurfurst, 1977, "Local Variability of Ground Ice Occurrence at Selected Sites in the Mackenzie Valley", Geological Survey of Canada, Open file 476. 
Heginbottom, J.A., P.J. Kurfurst, and J.S.O. Lau, 1978, "Regional Occurrence of Permafrost, Mackenzie Valley, Canada", in National Research Council of Canada, Proceedings of the Third International Conference on Permafrost 1978, Edmonton, Vol. 1, pp. 397-405.

Hernandez, H., 1973, "Natural Plant Recolonization of Surficial Disturbances, Tuktoyaktuk Peninsula Region, N.W.T." Canadian Joumal of Botany, Vol. 51, pp. 2177-2196.

, 1974, "Vegetation", in: Environment Protection Board, Environmental Impact Assessment of the Portion of the Mackenzie Gas Pipeline from Alaska to Alberta, Vol 4 (Research Reports), pp.37-68.

Hok, J.R., 1969, "A Reconnaissance of Tractor Trails and Related Phenomena on the North Slope of Alaska", U.S. Department of Interior, Bureau of Land Management, $66 \mathrm{p}$.

Hughes, O.L., 1972, "Surficial Geology and Land Classification, Mackenzie Valley Transportation Corridor", in: Legget, R.F. and I.C. MacFarlaine (eds.), Proceedings of the Canadian Northern Pipeline Research Conference, 2-4 February 1972.

Hughes, O.L., J.J. Veillette, J. Piliou, and P.T. Hanley, 1973, "Terrain Evaluation with Respect to Pipeline Construction, Mackenzie Transportation Corridor, Central Part, Lat $64^{\circ}$ to $68^{\circ} \mathrm{N}^{\prime \prime}$, Environmental-Social Program, Task Force on Northern Oil Development, Report No. 73-37.

Hughes, O.L., R.O. van Everdingen, and C. Tarnocai, 1983, "Regional Setting Physiography and Geology", in: French, H.M. and J.A. Heginbottom (eds.), Guidebook to Permafrost and Related Features of the Northern Yukon Territory and Mackenzie Delta, Canada, Fourth International Conference on Permafrost and International Geographical Union, Commission on the Significance of Periglacial Phenomena.

Hughes, O.L., N.W. Rutter, J.V. Mathews Jr., and J.J. Clague, 1989, "Unglaciated Areas" (Quaternary Stratigraphy and History, Canadian Cordillera), in: Fulton, R.J. (ed.), Quaternary Geology of Canada and Greenland, Chapter 1, Geology of Canada, No. 1.

Inter-Disciplinary Systems Ltd., 1973, "Report on the Norman Wells Winter Road Research Study, 1973", (unpublished report). 
Ironside, G.R., 1974, "Studies of Snowpack Winter Roads near Shingle Point, Northeastern Yukon Territory - Geobotanical Effects and Natural Revegetation".

Johnson, P.R. and C.M. Collins, 1980, "Snow Pads used for Pipeline Construction in Alaska, 1976. Construction, Use and Breakup", U.S. Army Cold Regions Research and Engineering Laboratory, CREEL Report 80-17.

Kerfoot, D.E., 1972, "Tundra Disturbance Studies of the Western Canadian Arctic", ALUR Report 71/72, Ottawa: Department of Indian Affairs and Northern Development.

Kershaw, G.P., B.J. Gallinger, and L.J. Kershaw, 1988, "Salix arbusculoides Anderss. Response to Denuding and Implications for Northern RightsOf-Way", in Senneset, K. (ed.): Permafrost, Fifth International Conference, Proceedings, Vol. 1, Tapir Publishers: Trondheim, Norway, pp. 599-604.

Kershaw, G.P., W. Shuguang, and K. Evans, "The Influence of a Simulated Pipeline Right-Of-Way on Snowpack Characteristics, SEEDS, Fort Norman, N.W.T.", paper presented as part of the Annual Metting of the Canadian Association of Geographers, Edmonton, Alberta, 29 May - 4 June 1990.

Keyes, Donald E., 1976, "Ice and Snow Construction", The Northern Engineer, 8(2), pp. 4-10.

Kosten, W. 1976, "Winter Roads and Working Pads, Operations and Scheduling", in: Mackenzie Valley Pipeline Inquiry, Exhibit \# 589.

Kurfurst, P.J., 1973, "Terrain Disturbance Susceptibility, Norman Wells Area, Mackenzie Valley", Environmental-Social Program, Task Force on Northern Oil Development, Report No. 73-24.

1974, "Terrain Sensitivity Evaluation and Mapping, Mackenzie Valley Transportation Corridor", Geological Survey of Canada, Report of Activities, 74-1, Part A, p. 279.

Lafferty, R., District Superintendant South, Department of Public Works and Highways, Hay River, N.W.T., Canada, letter to the author, 14 February 1990. 
Lau, J.S.O., and D.E. Lawrence, 1977, "Ground Ice and Water Contents of Frozen Soils in the Mackenzie Valley, Northwest Territories", Geological Survey of Canada, Open File 477.

Lawson, D.E., 1986, "Response of Permafrost Terrain to Disturbance: A Synthesis of Observations from Northern Alaska, U.S.A.", Arctic and Alpine Research, Vol. 18(1), pp. 1-17.

Linton, S., Winter Road Contractor, Norman Wells, Interview by the author, 21 August 1989.

Lotspeich, F.B. and A.E. Helmers, 1974, "Environmental Guidelines for Development Roads in the Subarctic", Environmental Protection Agency Report, EPA-660/3-74-009.

MacDonald, G. M., 1987, "Postglacial Vegetation History of the Mackenzie River Basin", Quaternary Research, Vol. 28, pp. 245-262.

Mackay, J.R., 1966, "Segregated Epigenetic Ice and Slumps in Permafrost, Mackenzie Delta Area, N.W.T.", Geographical Bulletin of Canada, Vol. 8, pp. 59-80.

1967, "Permafrost Depths, Lower Mackenzie Valley, Northwest Territories", Arctic, Vol. 20(1), pp. 21-26.

1975, "The Stability of Permafrost and Recent Climatic Change in the Mackenzie Valley, N.W.T.", Geological Survey of Canada, Paper 75-1, Part B, pp. 173-176.

1977, "Probing for the Bottom of the Active Layer", Geological Survey of Canada, Report of Activities, Part A, Paper 77-1A.

Mackay, J.R. and W.H. Mathews, 1973, "Geomorphology and Quaternary History of the Mackenzie River Valley near Fort Good Hope, N.W.T., Canada", Canadian Journal of Earth Sciences, Vol. 10(26), pp. 26-41.

Mathews, W.H., 1980, "Retreat of the last Ice-Sheets in Northwestern British Columbia and adjacent Alberta", Geological Survey of Canada, Bulletin 331. 
McClung, D.M., 1980, "Deformation and Failure Characteristics of Dry Snow", in: Sinha, N.K. (ed.), "Workshop on Winter Roads, 18-19 October 1979, Ottawa, Ontario", Ottawa: National Research Council, Associate Committee on Geotechnical Research, Technical Memorandum, No. 129.

Pettapiece, W.W., 1974a, "A Hummocky Permafrost Soil from the Subarctic of Northwestern Canada and Some Influences of Fire", Canadian Journal of Soil Science, Vol. 54(4), pp. 343-355. , 1974b, "Soils of the Subarctic in the Lower Mackenzie Basin", Arctic, Vol. 28(1), pp. 35-53.

Pettapiece, W.W. and S.C. Zoltai, 1974, "Soil Environments in the Western Canadian Subarctic", in: Mahaney, W.C. (ed.), Quaternary Environments, Toronto: University of Toronto Press (York University Series, Geographical Monographs), pp. 279-292.

Pettapiece, W.W., C.Tarnocai, S.C. Zoltai, and E.T. Oswald, 1978, Guidebook for a Tour of Soil, Permafrost and Vegetation Relationships in the Yukon and Northwest Territories of Northwestern Canada, Saskatoon: Saskatchewan Institute of Pedology.

Petzold, D. and A.N. Rencz, 1975, "The Albedo of Selected Subarctic Surfaces", Arctic and Alpine Research, 7, pp. 393-398.

Polar Gas Limited, 1984, "Polar Gas Project Application, Environmental Statement", Vol. 6.

Porsild, A.E. and W.J. Cody, 1980, Vascular Plants of Continental Northwest Territories, Canada, Ottawa: National Museum of Natural Sciences, 667 p.

Potter, J.G., 1965, Snow Cover, Climatological Studies, No. 3, Meteorological Branch, Department of Transportation, Ottawa.

Radforth, J.R., 1972, "Analysis of Disturbance Effects of Operation of Off-Road Vehicles on Tundra", Arctic Land Use Research Program, Department of Indian and Northern Affairs, Report 71-72-13.

, 1973, "Immediate Effects of Wheeled Traffic on Tundra during the Summer", Arctic Land Use Research Program, Department of Indian and Northern Affairs, Report 72-73-12, 32 p. 
Ramseier, R.O. and C.M. Keeler, 1966, "The Sintering Process in Snow", Journal of Glaciology, Vol. 6(45), pp. 421-424.

Reid, D.E., 1974, "Vegetation of the Mackenzie Valley", Part 1 \& 2, Report for Northern Engineering Services Company and Alaskan Arctic Gas Study Company.

Ripley, Klohn and Leonoff Alberta Ltd., 1970, "Mackenzie Valley Pipeline", Vol. III, Photo Mosaics and Pipeline Route, Sheet No. 1-46, Mile 1-1150.

Ritchie, J.C., 1984, Past and Present Vegetation of the Far Northwest of Canada, Toronto: University of Toronto Press.

Rouse, W.R., 1976, "Microclimatic Changes Accompanying Burning in Subarctic Lichen Woodland", Arctic and Alpine Research, Vol. 8(4), pp. 357-376.

, 1984, "Microclimate at Arctic Tree Line 1. Radiation Balance of Tundra and Forest, 2. Soil Microclimate of Tundra and Forest, 3. The Effects of Regional Advection on the Surface Energy Balance of Upland Tundra", Water Resources Research, Vol. 20(1), pp. 57-78.

Rouse, W.R. and K.A. Kershaw, 1971, "The Effects of Burning on the Heat and Water Regimes of Lichen-Dominated Subarctic Surfaces", Arctic and Alpine Research, Vol. 3(4), pp. 291-304.

Rouse, W.R. and R.L. Bello, 1983, "The Radiation Balance of Typical Terrain Units in the Low Arctic", Annals of the Association of American Geographers, Vol. 73(4), pp. 538-549.

Rowe, J.S., 1972, "Forest Regions in Canada", Department of Environment, Canada Forestry Service, Publication 1300.

Strang, R.M., 1973b, "Studies on Vegetation, Landform and Permafrost in the Mackenzie Valley: The Effects of Disturbances; Some Case Histories", Environmental-Social Program, Task Force on Northern Oil Development, Report No. 73-14, 37 p.

Tarnocai, C., 1973, "Soils of the Mackenzie River Area", Ottawa, Northern Pipelines, Task Force on Northern Oil Development, Report No. 73-26, 136p.

Viereck, L.A., 1973, "Wildfire in the Taiga of Alaska", Journal of Quatemary Research, 3, 465-495. 
Walker, D.A., D. Cate, J. Brown, and C.Racine, 1987, "Disturbance and Recovery of Arctic Alaskan Tundra Terrain. A Review of Recent Investigations", U.S. Army, Cold Regions Research and Engineering Laboratory, CRREL Report 87-11.

Wein, R.W. and L.C. Bliss, 1971, Northern Ecosystems and Northern Development.

White, J.M., Mathews, R.W., and Mathews, W.H., 1985, "Late Pleistocene Chronology and Environment of the Ice-Free Corridor of Northwestern Alberta", Quaternary Research, 24, pp. 173-186.

Wonders, William C, 1962, "Roads and Winter Roads in the Mackenzie Valley Area", (paper presented at the Annual Meeting, British Columbia Division, Canadian Association of Geographers, Vancouver, B.C.).

Younkin W.E. and L.R. Hettinger, 1978, "Assessment of the Effects of Snow Road Construction and Use on Vegetation, Surface Elevations and Active Layers near Inuvik, N.W.T.", in: Proceedings, Third International Conference on Permafrost, Edmonton, Ottawa: National Research Council, Vol. 1, pp. 481-486.

Zoltai, S.C., 1975, "Consideration of Impact on the Physical Environment", Mackenzie Valley Pipeline Inquiry, Exhibit \# 358.

Zoltai, S.C. and W.W. Pettapiece, 1973a, Terrain, Vegetation and Permafrost Relationships in the Northern Part of the Mackenzie Valley and Northern Yukon, Canada, Environmental Social Program, Northern Pipelines, Task Force on Northern Oil Development, Report No. 73-4, 98 p. , 1973b, "Surface Susceptibility Maps, 1:250,000", (unpublished).

Zoltai, S.C. and C. Tarnocai, 1974, "Soils and Vegetation of Hummocky Terrain", Environmental-Social Program, Task Force on Northern Oil Development, Report No. 74-5, 86 p.

Zoltai, S.C. and C. Tarnocai, 1975, "Perennially Frozen Peatlands in the Western Arctic and Subarctic of Canada", Canadian Joumal of Earth Sciences, Vol. 12, pp. 28-43. 


\section{APPENDIX A}

\section{TERRAIN SENSITIVITY AND SURFACE GEOLOGY IN THE LOWER AND CENTRAL MACKENZIE RIVER VALLEY}

Source: Anonymous (1975a) 

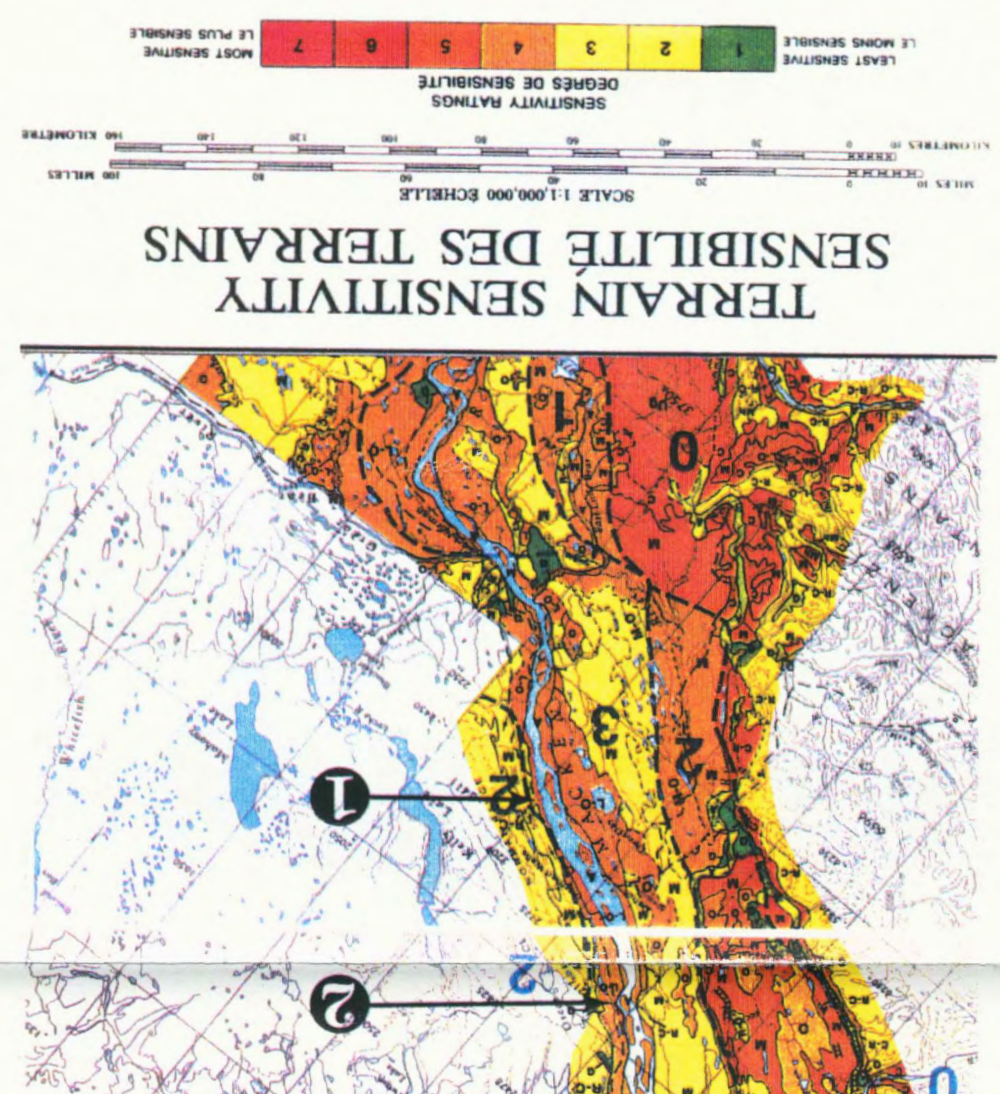

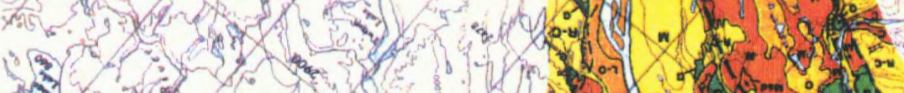

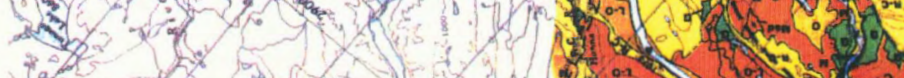

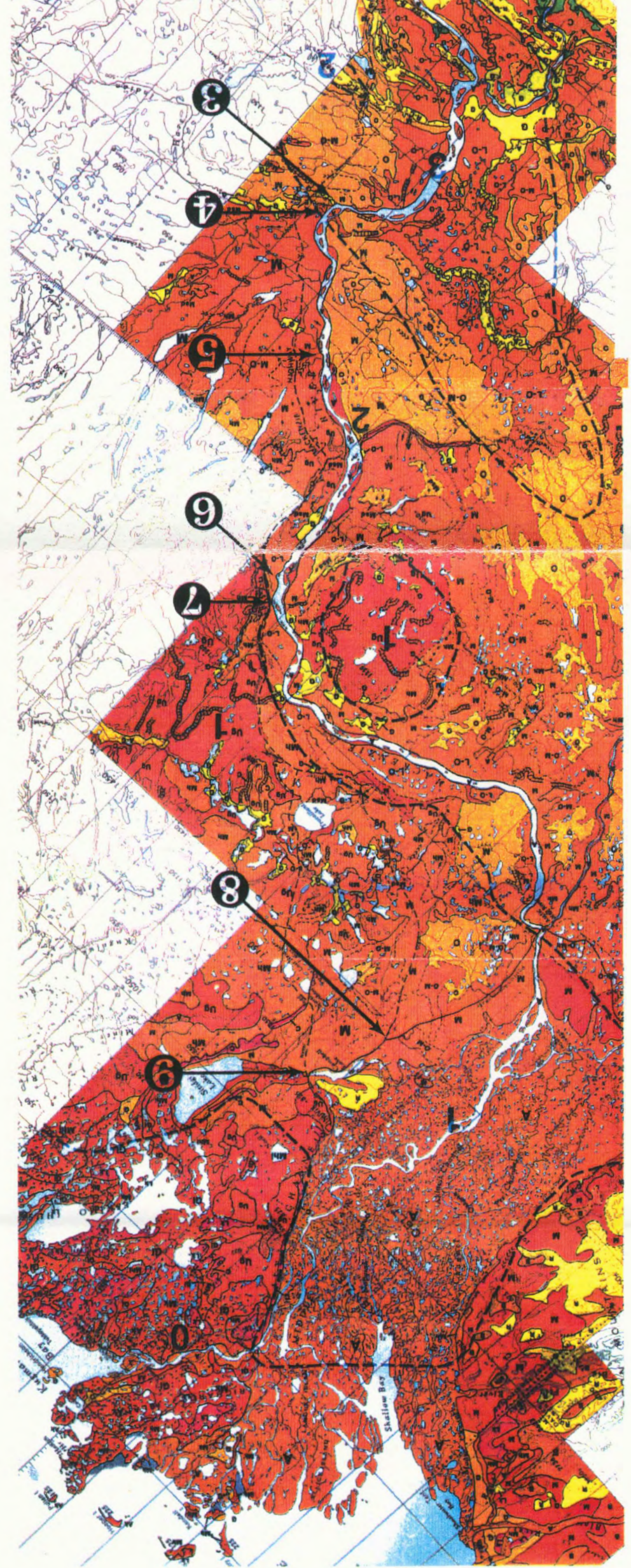


LEGEND

Drumlin, drumlinoidal ridge

Esker.

Beach ridgo....

-

Ecoregion boundary

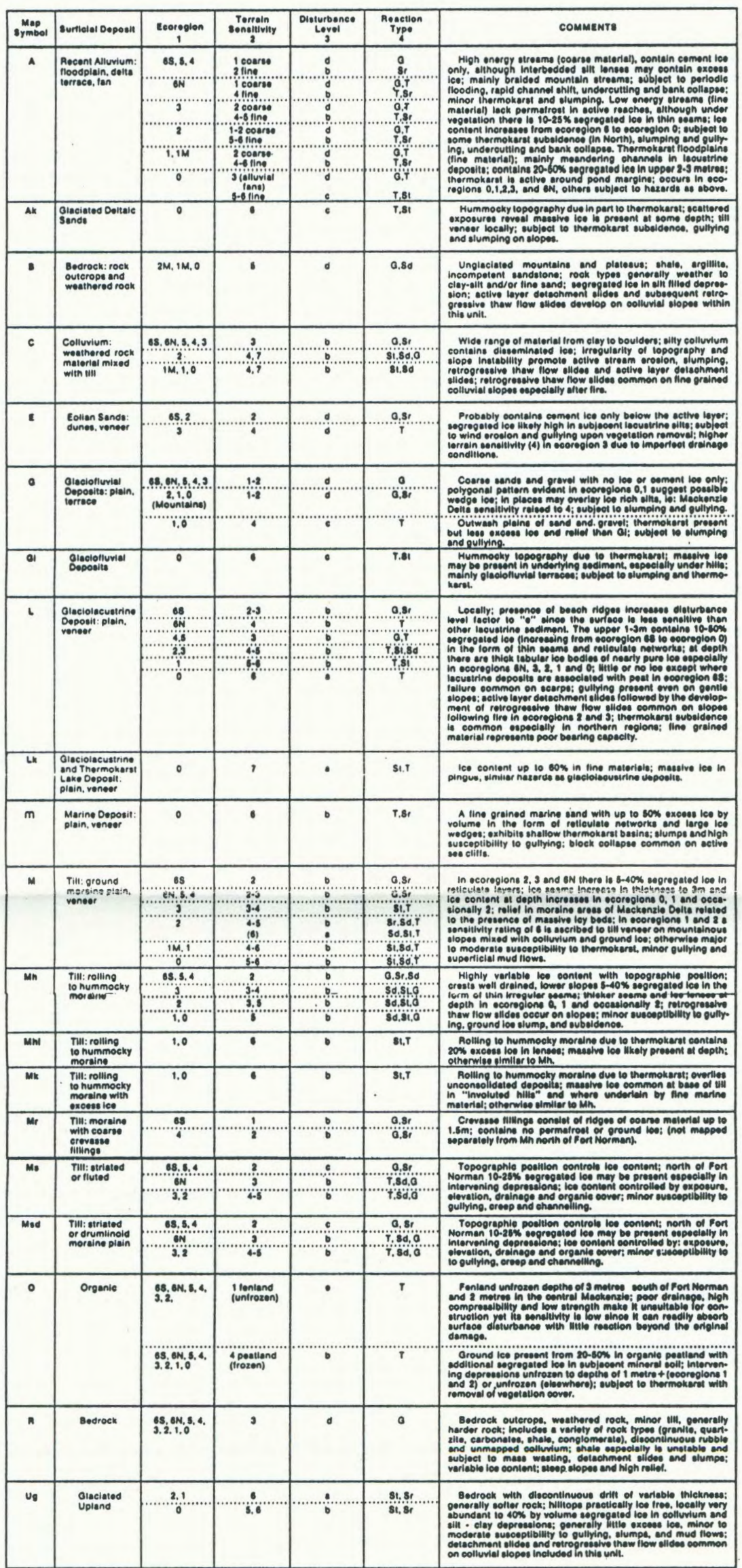

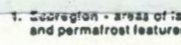

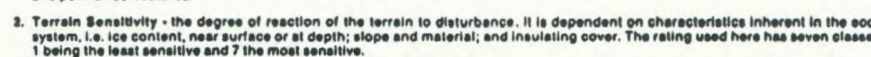

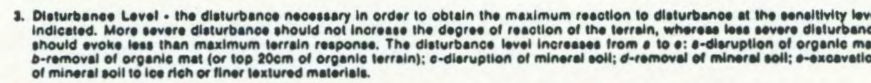

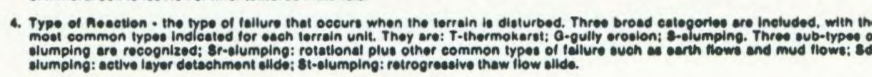
NOTES ON TEARAIN BeneitivitY

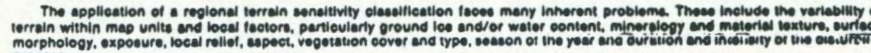

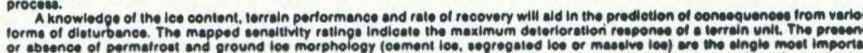

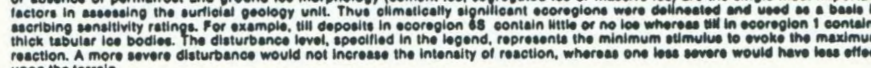

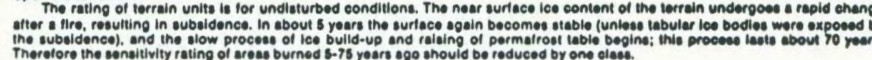

$$
\text { sounces }
$$

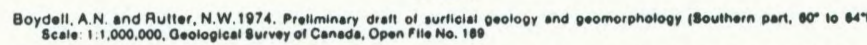

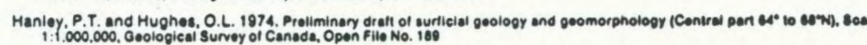

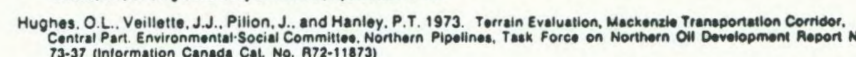

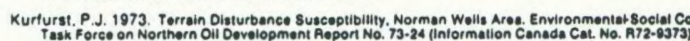

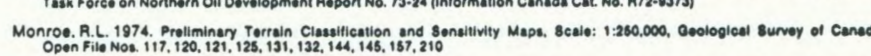

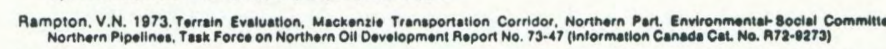

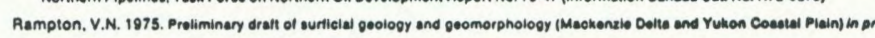

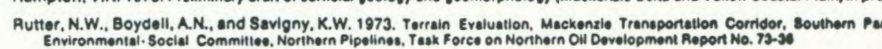


APPENDIX B

VEGETATION-LANDFORM UNIT ASSOCIATIONS IN THE LOWER AND CENTRAL MACKENZIE RIVER VALLEY 


\section{VEGETATION ASSOCIATIONS ON PRINCIPAL LANDFORM UNITS IN THE LOWER AND CENTRAL MACKENZIE RIVER VALLEY (modified from Rowe, 1974)}

\section{LACUSTRINE AND DELTAIC PLAINS}

\section{TERRAIN TYPE}

Well drained glacial

lake basin

Glacial lake basin

with slopewash

Thermokarst glacial lake basin

\section{SUBTYPE}

lacustrine plain

drainageway

plain and depression

palsa mounds and ridges

thaw pond

peat deposit

thaw pond

palsa mound and ridges

depression

thaw pond

peat deposits

thaw pond

peat deposit

thaw pond
VEGETATION ASSOCIATION

Picea mariana-Betula papyrifera/

Vaccinium vitis-idaea

P. mariana-Larix laricina $V$. uliginosum

open $P$. mariana/Ledum sp./ Cladonia sp.

B. papyriferalRosa acicularisSalix spp. and $P$. marianal Hylocomium sp.

Carex fen

scattered $P$. mariana/Cladonia sp./ Sphagnum spp.

Sphagnum bog

B. papyrifera/R acicularis-Salix spp. and $P$. mariana-B.

papyrifera $N$. vitis-idaea

open $P$. mariana/Ledum sp./

Cladonia sp.

Carex fen

scattered P. mariana/Cladonia sp./ Sphagnum spp.

Spagnum bog

scattered $P$. mariana/Cladonia sp.Shpagnum spp.

Sphagnum bog
Delta with peat deposits with peat deposits 


\section{VEGETATION ASSOCIATIONS ON PRINCIPAL LANDFORM UNITS IN THE LOWER AND CENTRAL MACKENZIE RIVER VALLEY (modified from Rowe, 1974) (continued)}

\section{DELTAIC AND OUTWASH PLAINS}

Deltaic sand plain

Delta with sand dunes

Delta with string bogs

Delta with thermokarst

Outwash

Outwash with meltwater channel sand plain

depressions

thaw ponds and abandoned channels

sand dune

interdune depression

channel or drainageway

palsa mound

palsa mound or ridge

depression

thaw pond

channel scarred

channel bottom
P. mariana-B. papyrifera/V. vitisidaea

open $P$. mariana/Ledum sp./ Cladonia sp.

Carex fen

P. mariana-B. papyrifera $\boldsymbol{V}$. vitisidaea

P. mariana/Hylocomium sp.

string fen

scattered $P$. mariana/Cladonia sp./ Shpagnum spp.

P. glauca/Hylacomium sp.

open $P$. mariana/Ledum sp./ Cladonia sp.

Carex fen

open $P$. mariana/Ledum sp./ Cladonia sp.

P. mariana-L. laricinal

$V$. uliginasum 


\section{VEGETATION ASSOCIATIONS ON PRINCIPAL LANDFORM UNITS IN THE LOWER AND CENTRAL MACKENZIE RIVER VALLEY \\ (modified from Rowe, 1974)}

(continued)

\section{TILL AND BEDROCK UPLANDS}

Ridge and knoll moraine

Eskers and kames

Bedrock

Thin till over bedrock till plain

depression

drumlin

thaw pond

peat deposit

drainageway

slopewash

ridges and knolls

ridges and bedrock

outcrops

tops of ridges or

mountains

thin till over bedrock
P. mariana-B. papyrifera $/ V$, vitisidaea and $B$. papyrifera/R. acicularis-Salix spp.

open $P$. mariana/Ledum sp./ Cladonia sp.

P. mariana-B. papyrifera/ $V$, vitisidaea

Sphagnum bog

scattered P. mariana/Cladonia sp/ with peat deposits

P. mariana-L. laricina/V. uliginosum

P. mariana-B. papyrifera/V. vitisidaea

P. glauca-B. papyrifera/Alnus crispa

open gnarled $P$. glauca- $L$. laricina/Dryas sp./Cetraria sp.

P. glauca-B. papyrifera/A crispa and open P. mariana/Ledum sp./ Cladonia sp. 


\section{VEGETATION ASSOCIATIONS ON PRINCIPAL LANDFORM UNITS \\ IN THE LOWER AND CENTRAL MACKENZIE RIVER VALLEY \\ (modified from Rowe, 1974) \\ (continued)}

\section{HIGH TERRACE AND FLUVIAL LOWLANDS}

High Terrace

terrace

drainageway and

depression

Alluvial meander plains

Alluvial floodplains

Fossil floodplains

Old slope failures low terrace and levee

point bar

backswamp

abandoned channel infilling

low terrace

point bar

terrace or island

backswamp

abandoned channel

undisturbed surface of slump

slip face of slump open Picea mariana/Ledum sp./

Cladonia sp.

P. mariana-Larix laricina/

Vaccinium vitis-idaea

P. glauca/Hylocomium sp. and Populus balsamifera/Alnus incana/ Equisetum sp.

Salix spp.-A. incana/Epilobium sp.

P. balsamifera/Hylocomium sp.

Carex fen

P. balsamifera/A. incana/ Equisetum sp.

Salix spp. $A$. incana

P. glauca/Hylacomium sp.

open $P$. mariana/Ledum sp./

Cladonia sp.

Carex fen

P. mariana- B. papyrifera/

V. vitis-idaea

P. glauca/Hylocomiumsp. 


\section{APPENDIX C}

SUMMARY OF STUDY SITE CHARACTERISTICS AND DISTURBANCE ACCOUNTS OF INVESTIGATED RIGHT-OF-WAYS 
SITE:

LOCATION:

ELEVATION:

LANDFORM UNIT:

SURFACE DEPOSITS: glaciolacustrine deposits; silty clay tills

SOILS (at transect 1): Turbic Cryosols

\section{VEGETATION:}

(control area)

TRANSECT 1: immature Picea mariana / Alnus crispa / Vaccinium vitis-idaea

TRANSECT 2: $\quad$ immature $P$. mariana - Betula glandulosa / V. vitisidaea

TRANSECT 3: $\quad$ immature P. mariana / Artostaphylos rubra

DISTURBANCE: presently used processed-snow-road, operated perennially for at least 18 years (Mackenzie Highway right-of-way, refer to Chapter II). 
SITE:

LOCATION:

ELEVATION:

LANDFORM UNIT: SURFACE DEPOSITS: fine sand and silt, some silty clay

SOILS (at transect 1): Orthic Turbic Cryosols

\section{VEGETATION:}

(control area)

TRANSECT 1: $\quad$ P. mariana / Ledum spp.

TRANSECT 2: $\quad$ Salix sp. - Betula glandulosa

TRANSECT 3: $\quad$ P. glauca - B. papyrifera / Equisetum arvense

\section{\# 2 (Oscar Creek)}

$65^{\circ} 26^{\prime} \mathrm{N} 127^{\circ} 25^{\prime} \mathrm{W}$

$55 \mathrm{~m}$

deltaic sand plain \& dunes / alluvial meander plain

DISTURBANCE:

presently used processed snow road (operative since 1988/89), initial right-of-way clearing 1970/71, operative compacted snow road operative until 1979 (Mackenzie Highway, refer to Chapter II), abandoned from 1975 until 1988. 
SITE:

LOCATION:

ELEVATION:

LANDFORM UNIT:

SURFACE DEPOSITS: aeolian fine sands and silty sands

SOILS:

VEGETATION:

(control area)

TRANSECT 1: $\quad$ Picea mariana / Vaccinium spp.

TRANSECT 2: $\quad$ P. mariana / feathermosses

TRANSECT 3: $\quad$ P. mariana/ Sphagnum spp.

\section{\# 3 (Jackfish Creek)}

$66^{\circ} 15^{\prime} \mathrm{N} 128^{\circ} \mathrm{N} 37^{\prime} \mathrm{W}$

$60 \mathrm{~m}$

sand dunes

Orthic Static Cryosol

DISTURBANCE:

presently used processed snow road (operative since $1988 / 89$ ), initial right-of-way clearing in 1970/71, compacted snow road operative until 1975 (Mackenzie Highway, refer to Chapter II), abandoned from 1975 until 1988. 
SITE:

LOCATION:

ELEVATION:

LANDFORM UNIT:

SURFACE DEPOSITS:

SOILS (at transect 2): Orthic Humic Gleysol

\section{VEGETATION:}

(control area)

TRANSECT 1: $\quad$ Picea glauca / Juniper communis

TRANSECT 2: $\quad$ P. mariana / Dryas integrifolia

TRANSECT 3: $\quad$ burned $P$. mariana / Carex spp.

TRANSECT 4: $\quad$ P. mariana / ericaceous shrubs

DISTURBANCE:

winter trail, right-of-way clearing and operative in winter and spring 1972 , used since then by snowmobiles. 
SITE:

LOCATION:

ELEVATION:

LANDFORM UNIT:

SURFACE DEPOSITS: colluvial shale-, silt-, and limestone

SOILS:

VEGETATION:

(control area)

TRANSECT 1: $\quad$ riparian Picea mariana / Sphagnum sp.

TRANSECT 2: $\quad$ upland steep slope Picea mariana / dwarf heath shrubs

TRANSECT 3: $\quad$ steep slope Arctostaphylos uva-ursi - Dryas integrifolia

TRANSECT 4: $\quad$ sparse steep slope Dryas integrifolia

TRANSECT 5: $\quad$ sparse steep slope Dryas integrifolia

TRANSECT 6: $\quad$ upland Picea glauca / dwarf heath shrubs
\# 5 (Tieda River)

$66^{\circ} 37^{\prime} \mathrm{N} 129^{\circ} 19^{\prime} \mathrm{W}$

$45-95 \mathrm{~m}$

steep scree slope, bedrock escarpment

Orthic Regosols 
SITE:

LOCATION:

ELEVATION:

LANDFORM UNIT:

SURFACE DEPOSITS:

SOILS:

VEGETATION:

(control area)

TRANSECT 1: $\quad$ upland Picea mariana / mat-forming ericaceous shrubs

TRANSECT 2: $\quad$ upland Picea glauca / ericaceous shrubs

TRANSECT 3: $\quad$ lowland Betula glandulosa / Equisetum arvense

TRANSECT 4: $\quad$ pioneer upland Salix spp. - Alnus crispa (recent forest fire)

DISTURBANCE:
\# 6 (Little Chicago)

$67^{\circ} 12^{\prime} \mathrm{N} 130^{\circ} 12^{\prime} \mathrm{W}$

$60 \mathrm{~m}$

rolling glacial lake basin modified by channel incisement

glaciolacustrine sandy silts

Orthic Turbic Cryosols 
SITE:

LOCATION:

ELEVATION:

LANDFORM UNIT:
\# 7 (Charrue River)

$67^{\circ} 17^{\prime} \mathrm{N} 133^{\circ} 21^{\prime} \mathrm{W}$

$37-60 \mathrm{~m}$

glacial lake basin modified by channel incisement

SURFACE DEPOSITS: glaciolacustrine silty clays

SOILS:

Orthic Turbic Cryosols

VEGETATION:

burned approximately two years before field visit

(control area)

TRANSECT 1: $\quad$ pioneer Salix spp. / Equisetum scirpoides

TRANSECT 2: $\quad$ pioneer Equisetum scirpoides - Epilobium angustifolium

TRANSECT 3: $\quad$ pioneer Epilobium angustifolium

TRANSECT 4: $\quad$ pioneer Epilobium angustifolium

DISTURBANCE: Canadian National Telecommunications

(CNT) right-of-way, refer to Chapter II. 
SITE:

LOCATION:

ELEVATION:

LANDFORM UNIT:

TRANSECT 1: esker

TRANSECT 2: esker

TRANSECT 3: fen wetland

TRANSECT 4: $\quad$ alluvial floodplain (imperfectly drained)

TRANSECT 5: alluvial floodplain (well drained)

SURFACE DEPOSITS:

TRANSECT 1: $\quad$ coarse gravels, sand, silt

TRANSECT 2: $\quad$ coarse gravels, sand, silt

TRANSECT 3: silty clay till (moraine veneer)

TRANSECT 4: $\quad$ stratified silt, sand, and gravel

TRANSECT 5: $\quad$ stratified silt, sand, and gravel

SOILS (transect 5): $\quad$ Dystric Brunisol
\# 8 (Mackenzie Highway - Dempster Highway

$6^{\circ} 57^{\prime} \mathrm{N} 133^{\circ} 28^{\prime} \mathrm{W}$

$80 \mathrm{~m}$

alluvial floodplain, fen wetland, esker

\author{
d)
}


SITE:

(continued)

DISTURBANCE:
\# 8 (Mackenzie Highway - Dempster Highway Junction)

Mackenzie Highway right-of-way, refer to Chapter II. 
SITE:

LOCATION:

ELEVATION:

LANDFORM UNIT:

SURFACE DEPOSITS: ground moraine tills and glaciolacustrine silty clays

SOILS (transect 1):

VEGETATION:

(control area)

TRANSECT 1: $\quad$ Picea mariana / ericaceous shrub / Sphagnum sp.

TRANSECT 2: $\quad$ P. mariana / Betula glandulosa / ericaceous shrubs

TRANSECT 3: $\quad$ P. mariana / ericaceous shrubs / Sphagnum sp.
\# 9 (Campbell Creek)

$68^{\circ} 35^{\prime} \mathrm{N} 133^{\circ} 14^{\prime} \mathrm{W}$

$15 \mathrm{~m}$

ridge- and knoll-moraine

Regosolic Static Cryosol

\section{DISTURBANCE:}

Canadian National Telecommunications (CNT) right-of-way, refer to Chaper II. 


\section{APPENDIX D}

COVER ESTIMATES FOR VASCULAR AND NON-VASCULAR PLANTS ON THE INVESTIGATED WINTER-ROAD-RIGHT-OF-WAYS 
CODES FOR MODIFIED BRAUN-BLANQUET

COVER-ABUNDANCE SCALE

$$
\begin{aligned}
& r=\text { solitary, small cover } \\
& +=\text { few, small cover } \\
& 1=\text { numerous, but }<5 \% \\
& 2=5-25 \% \\
& 3=25-50 \% \\
& 4=50-75 \% \\
& 5=>75 \%
\end{aligned}
$$

$$
\begin{aligned}
& \mathrm{WR}=\text { winter road } \\
& \mathrm{LE}=\text { road shoulder } \\
& \mathrm{CO}=\text { control } \\
& \mathrm{SD}=\text { snowmobile trail }
\end{aligned}
$$




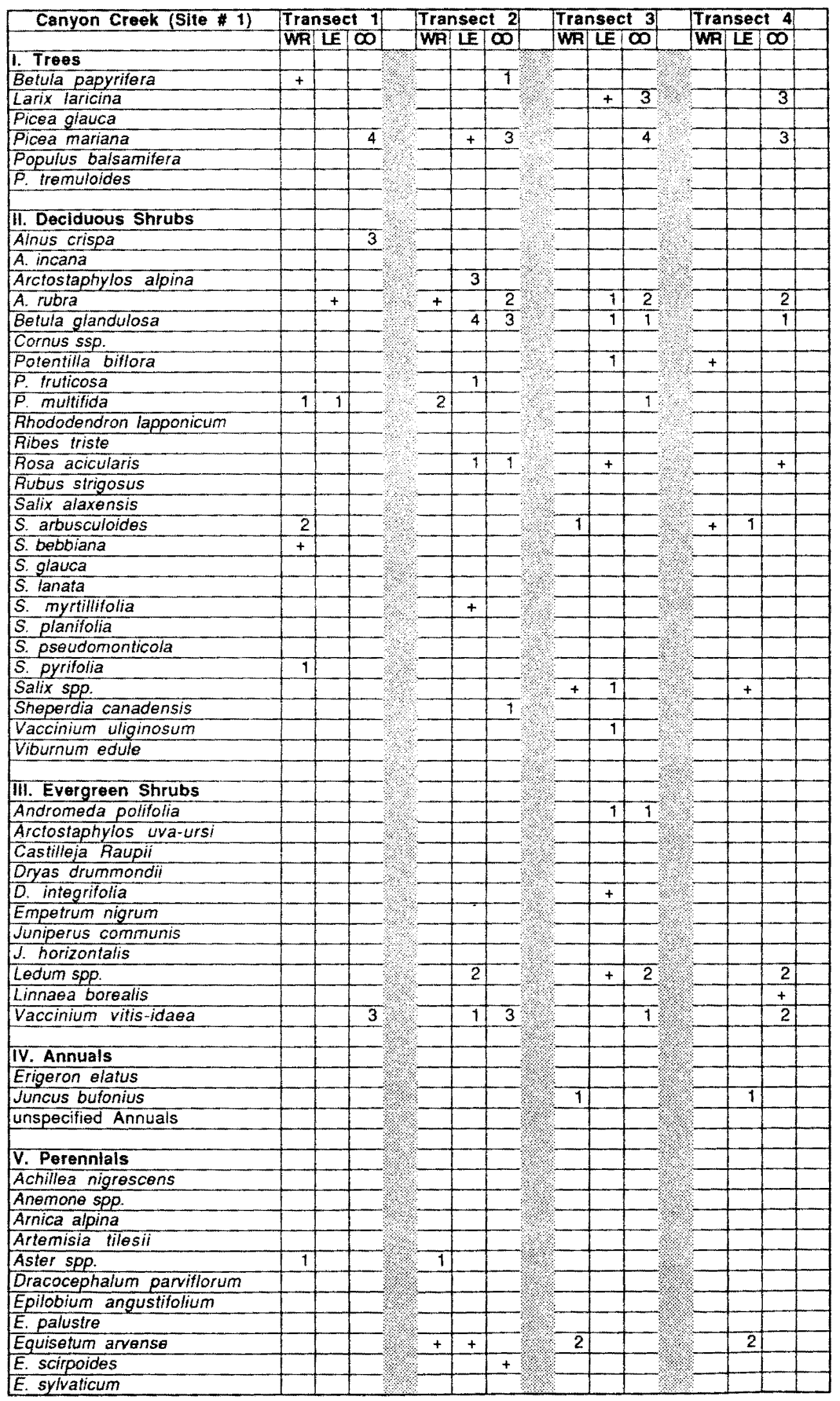




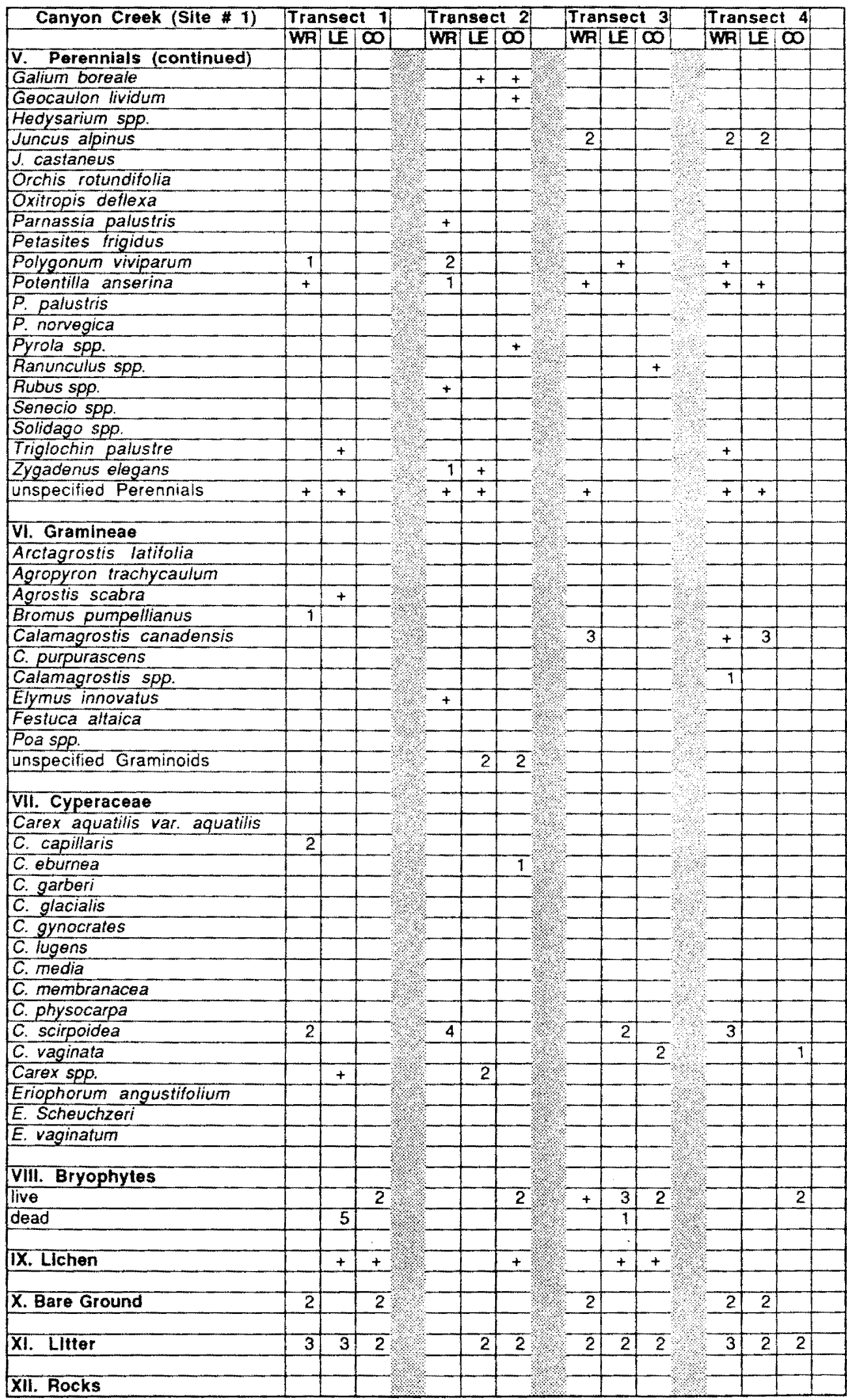




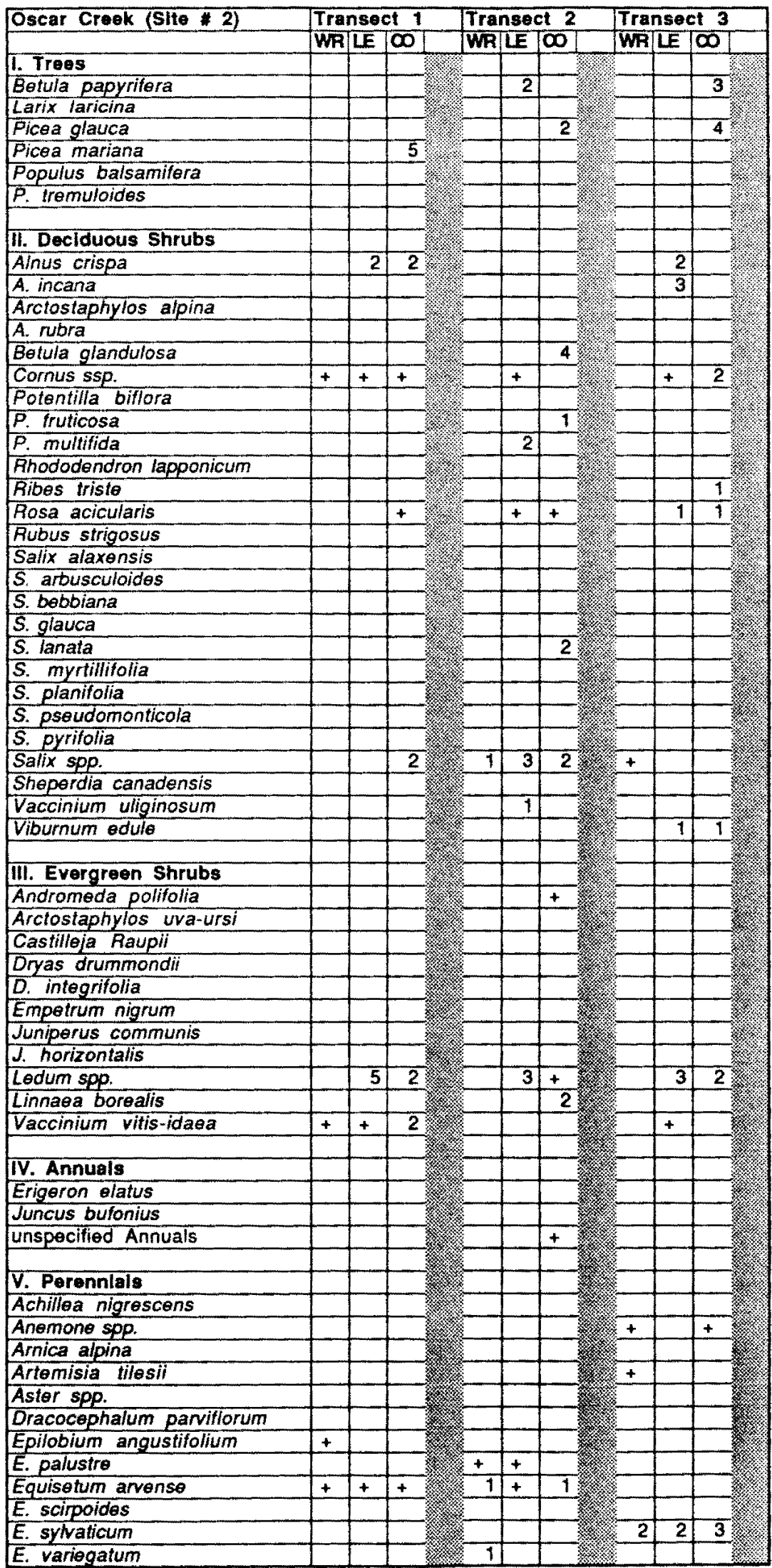




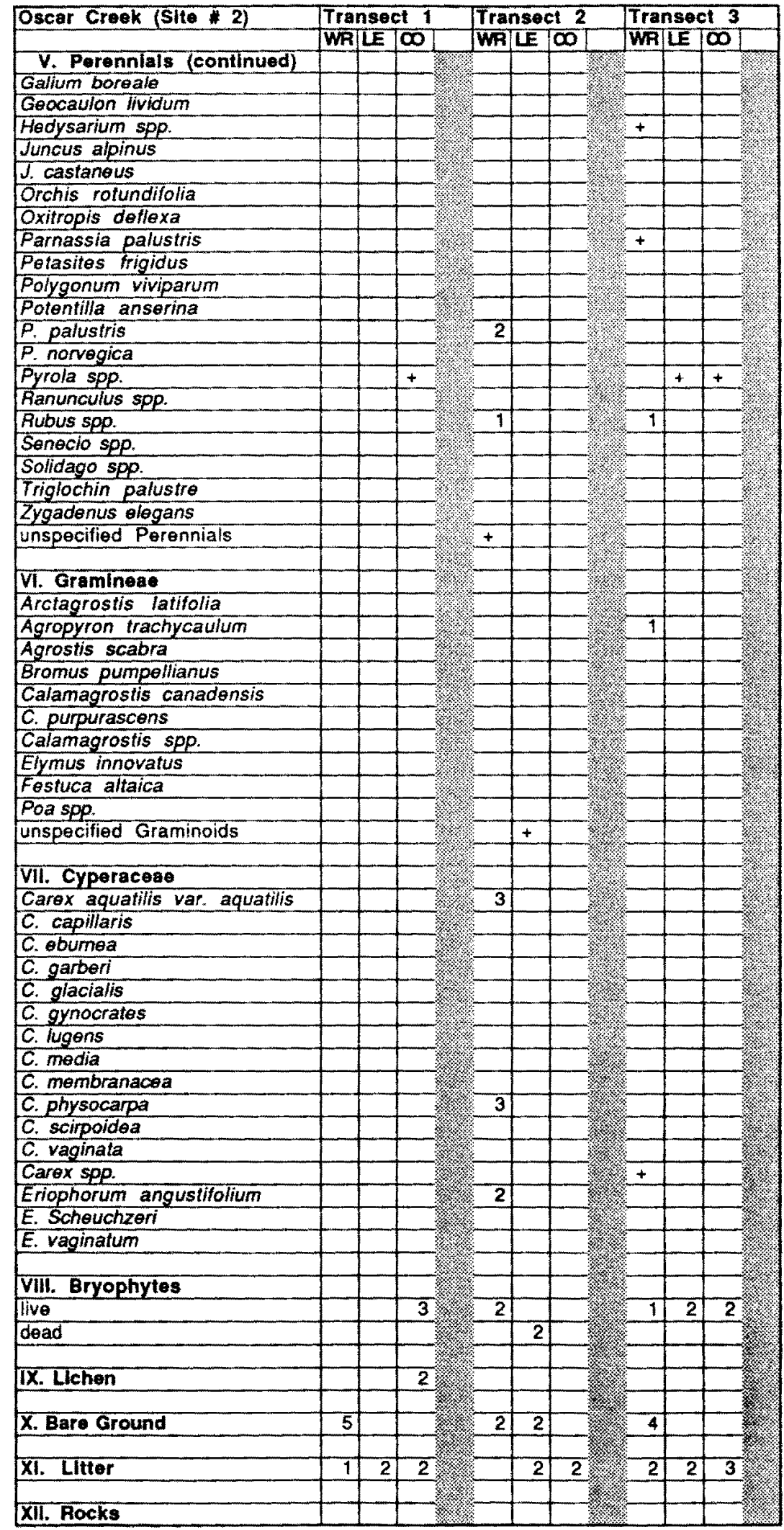









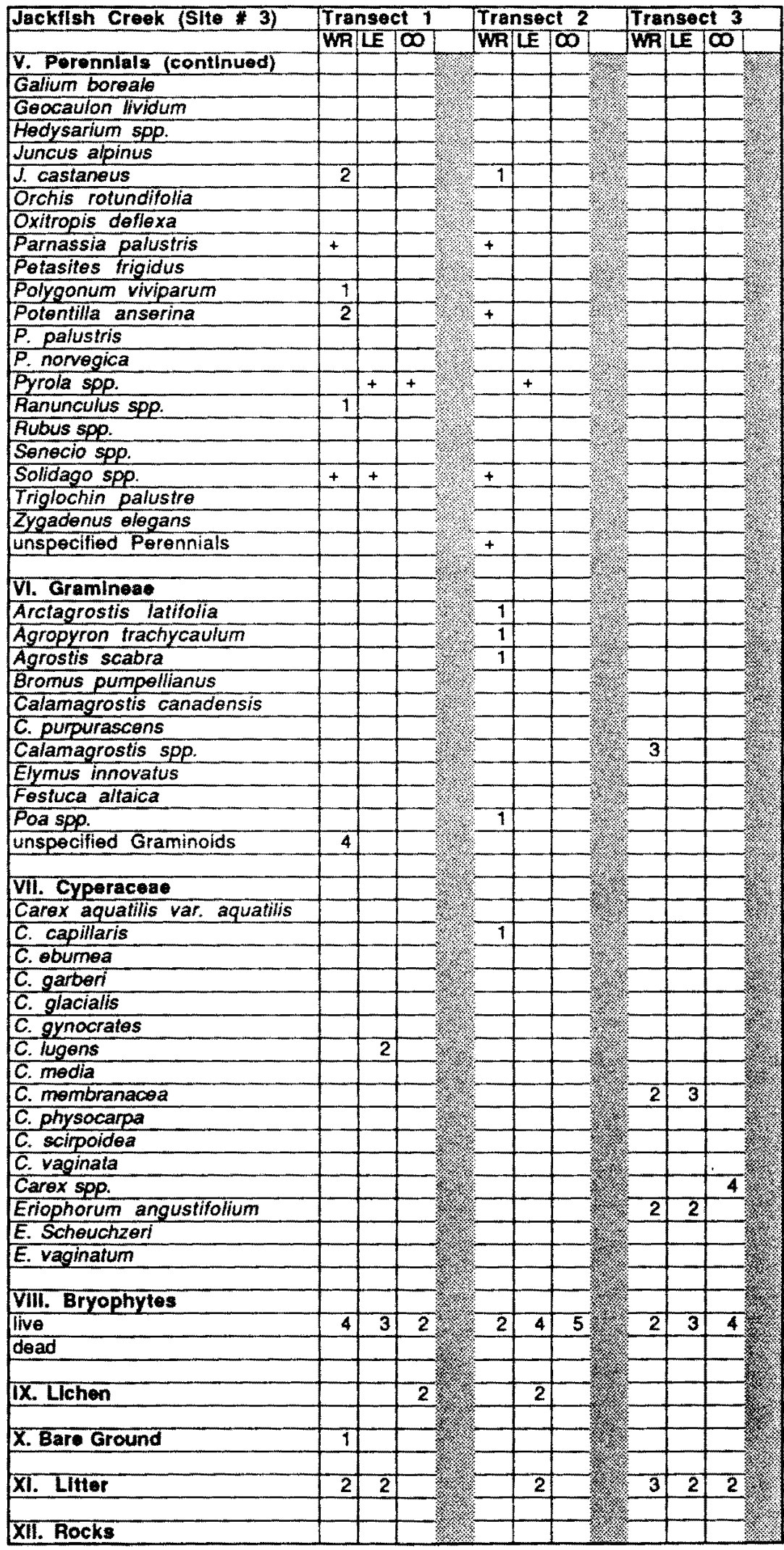




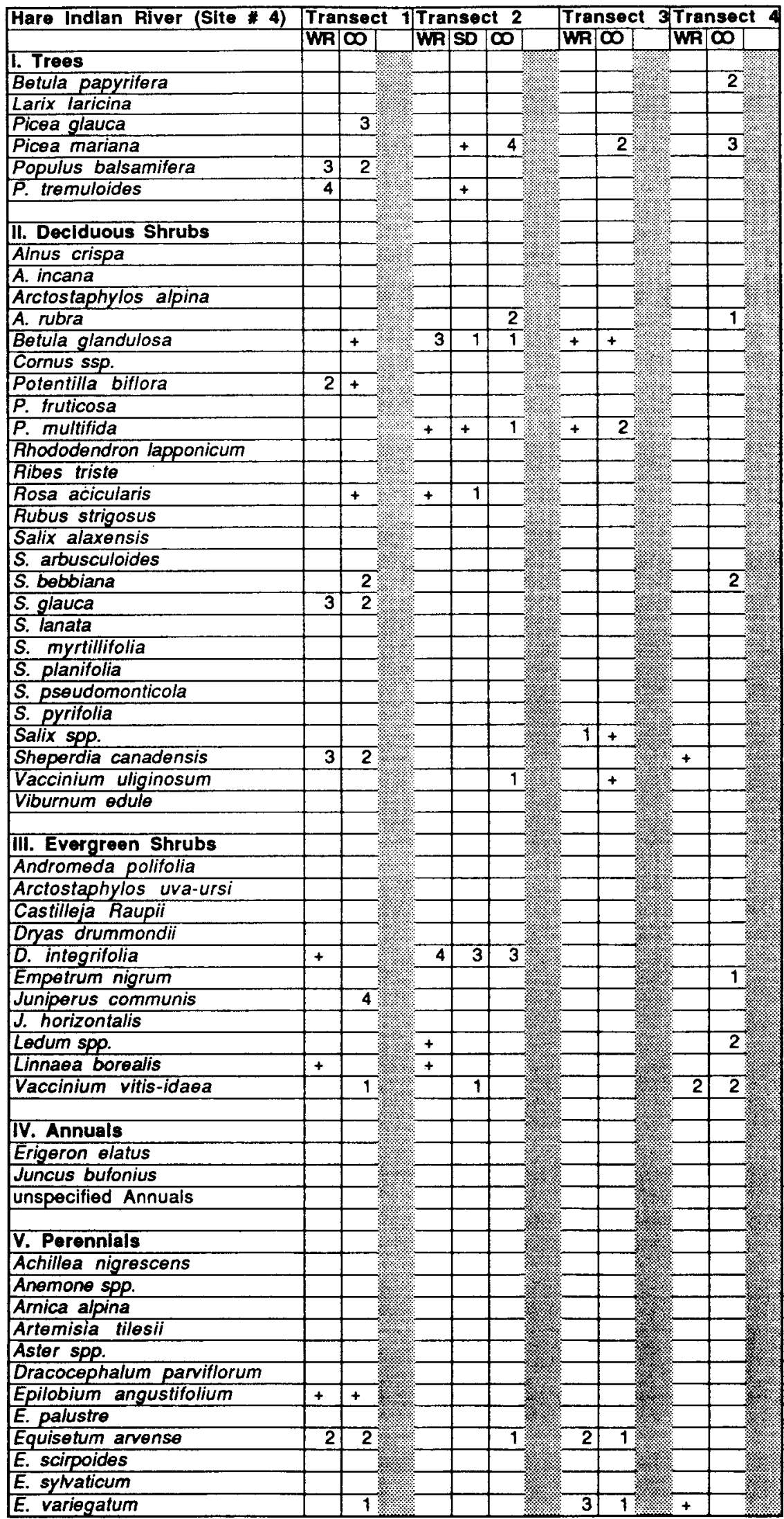




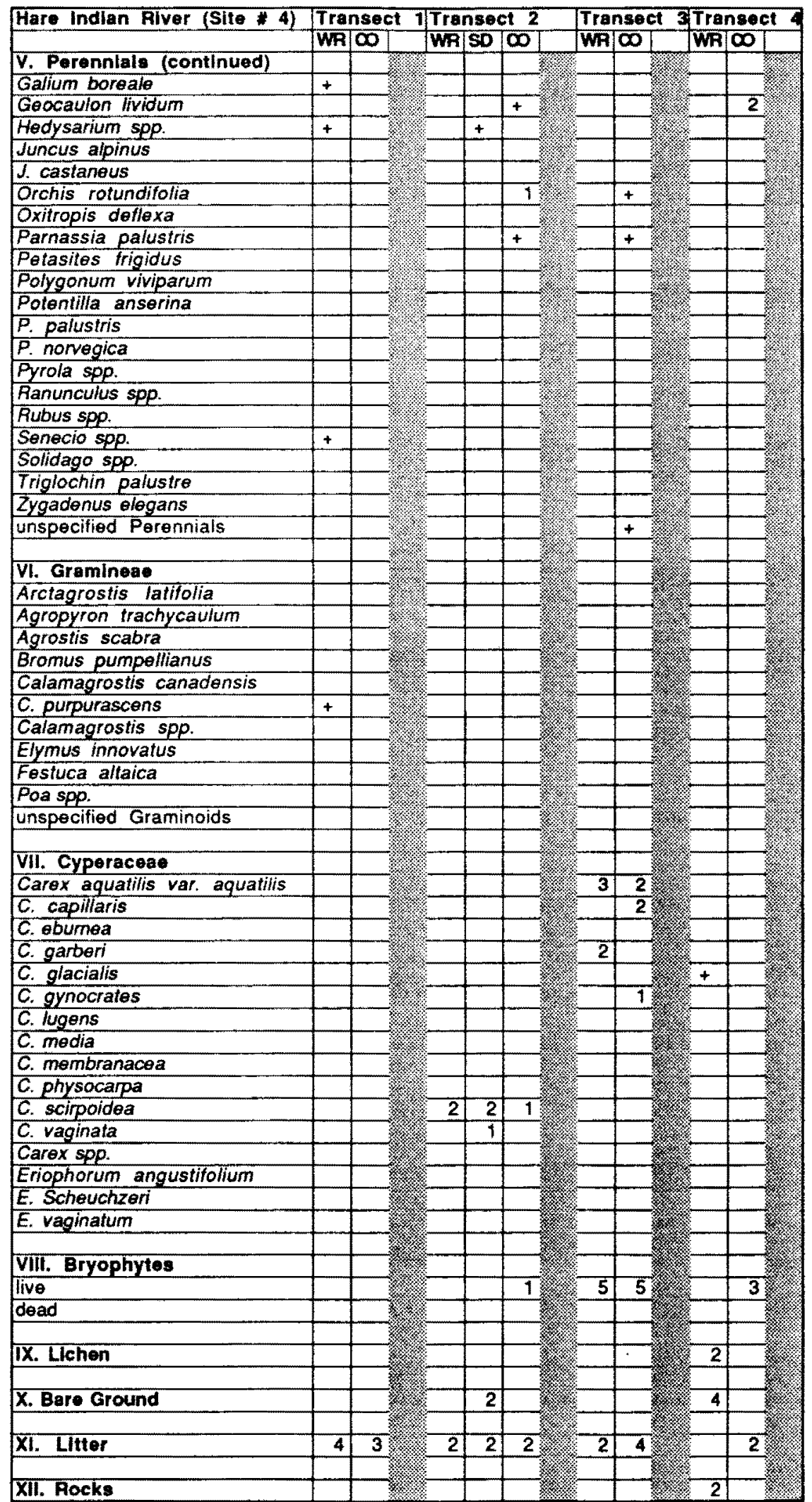




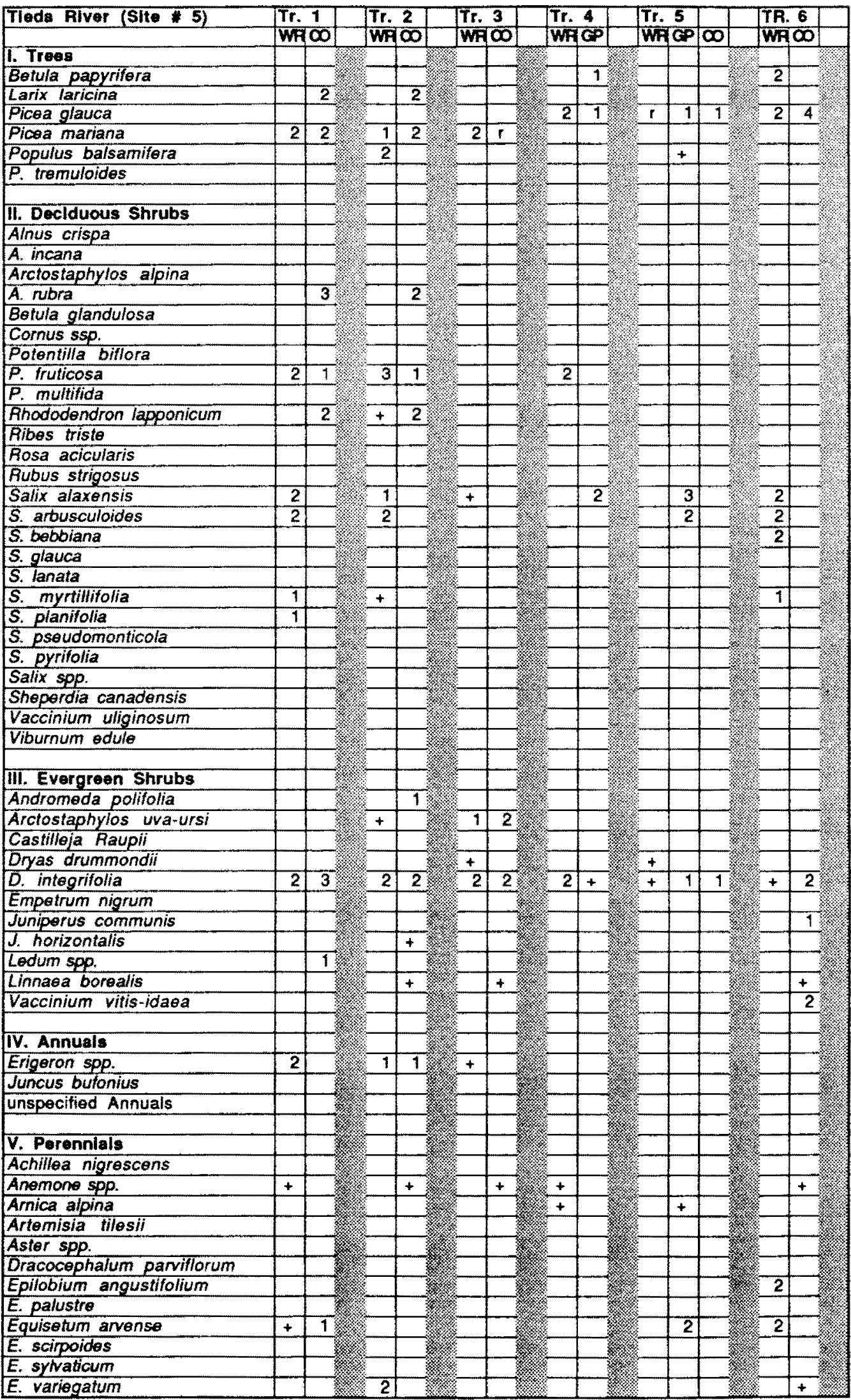




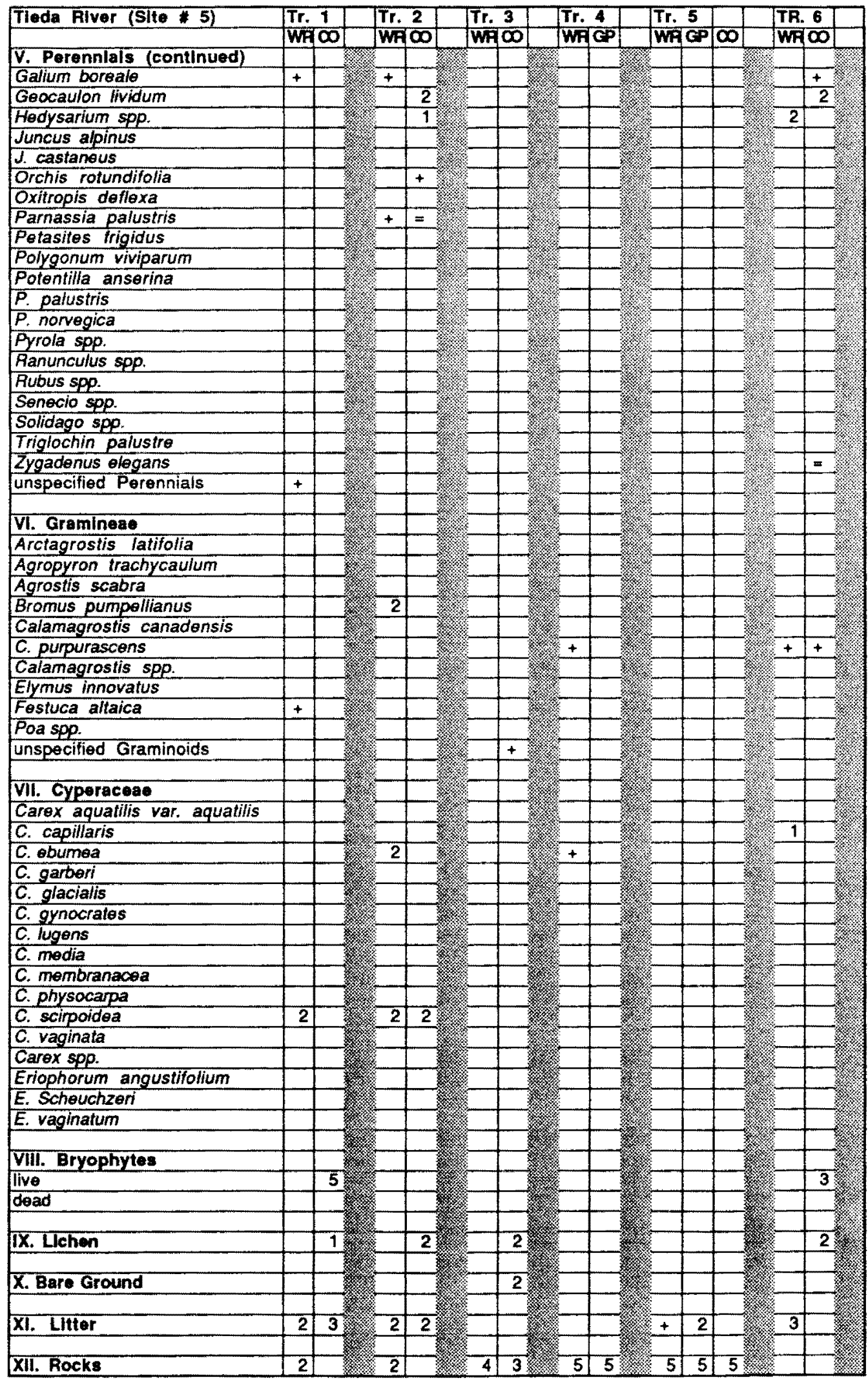




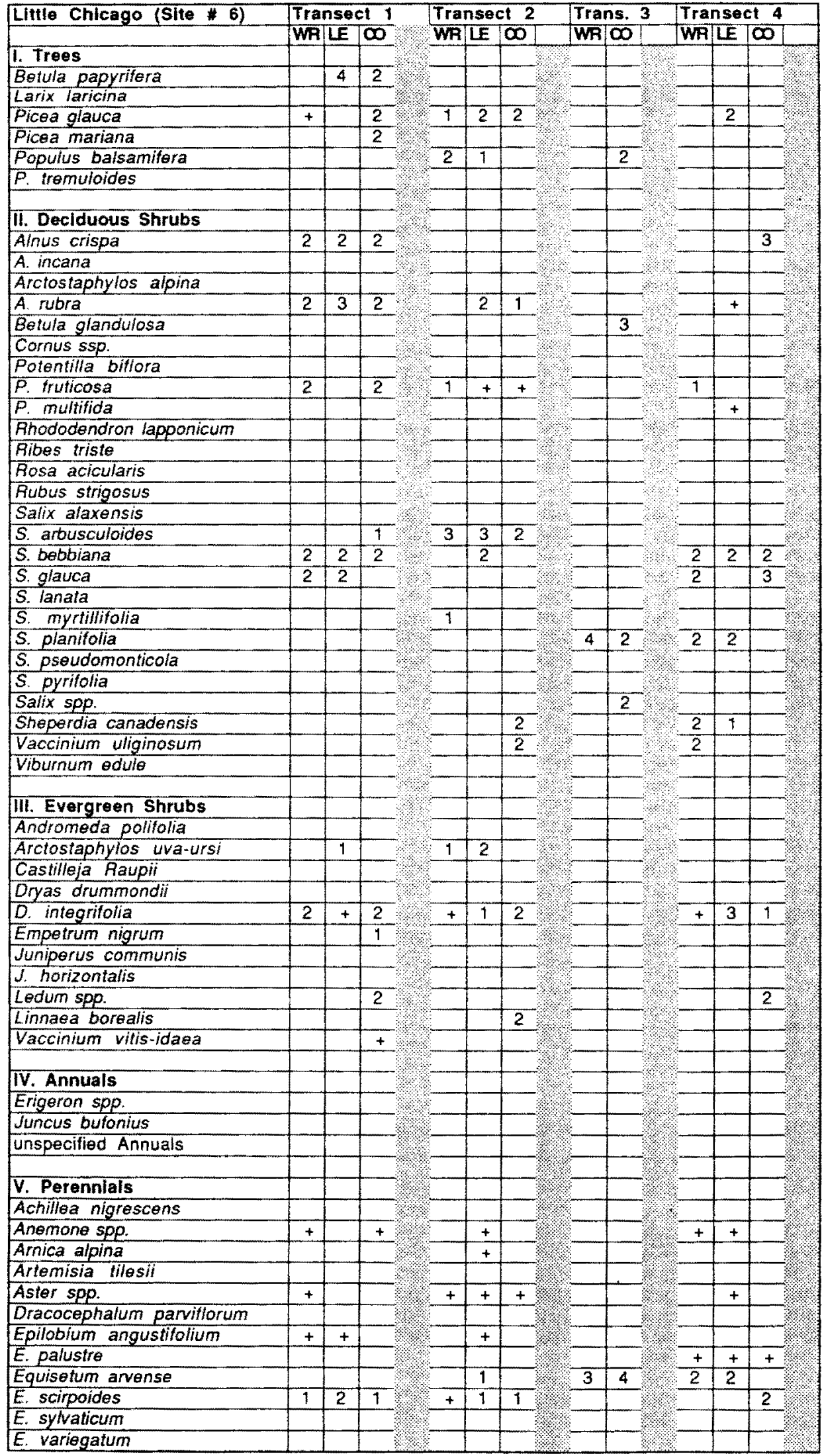




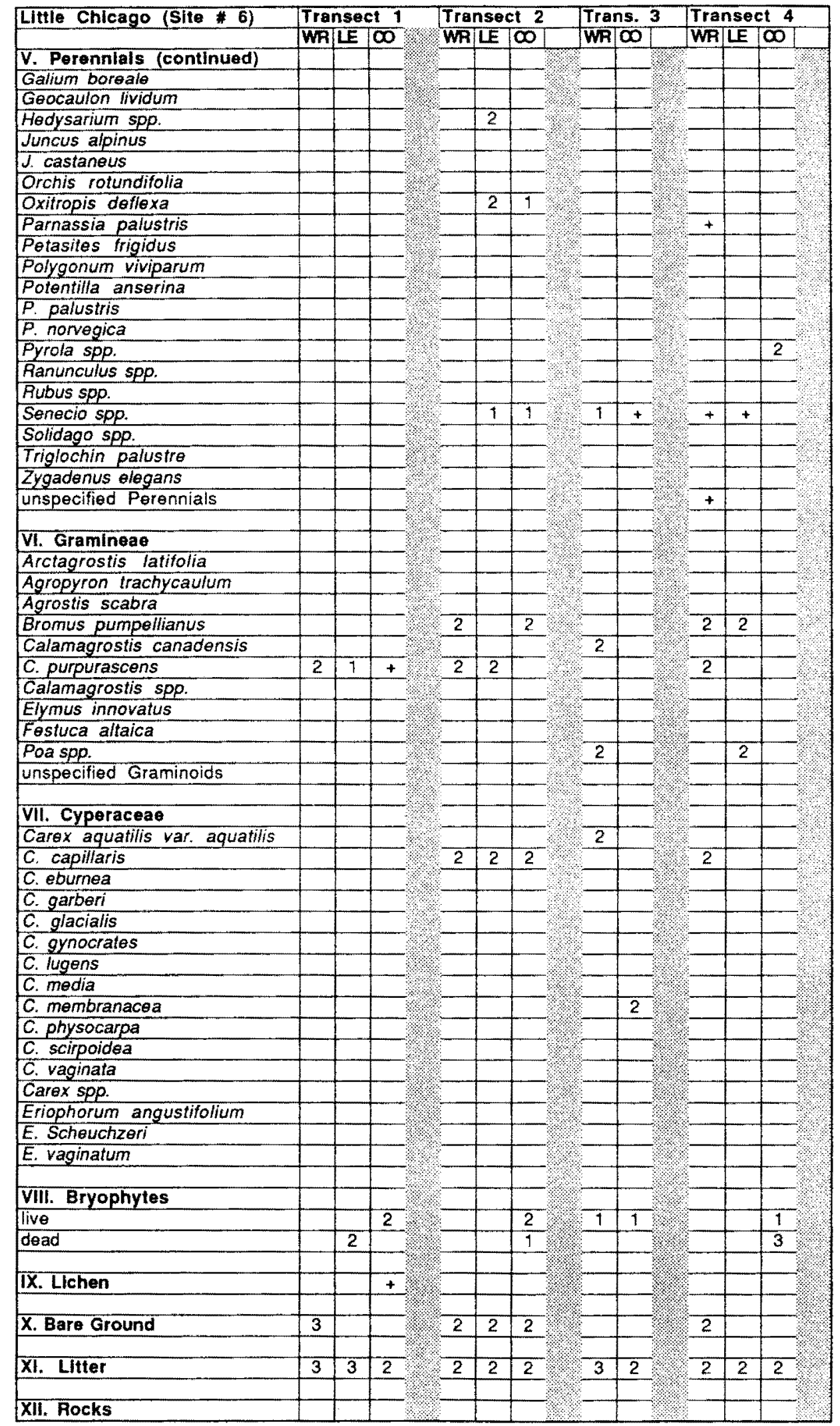




\begin{tabular}{|c|c|c|c|c|c|c|c|c|c|c|c|c|c|c|}
\hline Charrue River (Site \#7) & $\begin{array}{l}T \text { Tra } \\
\text { WR }\end{array}$ & का. & & Trar & IS. & 2 & & Tran & $\frac{18 .}{L E}$ & $\infty$ & & $\begin{array}{l}\text { Tran } \\
\text { Wall }\end{array}$ & IS. & $\infty$ \\
\hline 1. Trees & & & & & & & & & & & & & & \\
\hline Betula papyritera & & & & & & & & & & & & & & \\
\hline Larix laricina & & & & & & & & & & & & & 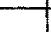 & \\
\hline Picea glauca & & & & & & & & & & & & & 1 & \\
\hline Picea mariana & & & & & & & & & & & & & & \\
\hline Populus balsamifera & & & & & & & & & & & & & & \\
\hline P. tremuloides & & & & & & & & & & & & & & \\
\hline & & & & & & & & & & & & & & \\
\hline II. Deciduous Shrubs & & & & & & & & & & & & & & \\
\hline Alnus crispa & & & & & & & & & & & & & & \\
\hline A. incana & & & & & & & & & & & & & & \\
\hline Arctostaphylos alpina & & & & & & & & & & & & & & \\
\hline A. rubra & 1 & 1 & & & & 2 & & 1 & & & & & & \\
\hline Betula glandulosa & & & & & & & & & & & & & & \\
\hline Cornus ssp. & & & & & & - & & 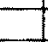 & - & 5 & & 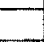 & 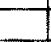 & E \\
\hline Potentilla biffora & & & & & & 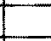 & & & & & & & & \\
\hline P. truficosa & & & & & & & & & & & & & & \\
\hline P. mulifida & 2 & & & 1 & & 1 & & 2 & & 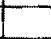 & & & & \\
\hline Rhododendron lapponicum & & & & & & & & & & & & & & \\
\hline Ribes triste & & & & & & & & & & & & & & \\
\hline Rosa acicularis & & & & & & & & & & 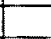 & & & 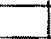 & \\
\hline Rubus strigosus & & & & & & & & & & & & & 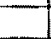 & \\
\hline Salix alaxensis & & & & & & & & & & & & & - & \\
\hline S. arbusculoides & 3 & 2 & & & & & & & & 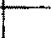 & & & - & \\
\hline S. bebbiana & & & & & & 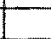 & & & & & & & & \\
\hline S. glauca & & 2 & & & & 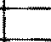 & & 2 & & 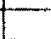 & & & 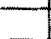 & \\
\hline S. lanata & & & & & & & & & & & & & & \\
\hline s. myrtillifolia & & & & & & 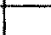 & & & & & & & ( & \\
\hline S. planifolia & & & & & & & & & & & & & & \\
\hline S. pseudomonticola & 2 & & & & & 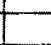 & & & & & & & 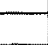 & \\
\hline S, pyrifolia & & & & & & & & & & & & & 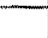 & \\
\hline Salix spp. & & & & & & 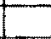 & & & + & & & & 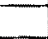 & + \\
\hline Sheperdia canadensis & & & & & & & & & & & & & 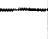 & \\
\hline Vaccinium uliginosum & & & & & & 1 & & & & & & & . & \\
\hline Viburnum odule & & & & & & & & & & & & & 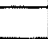 & \\
\hline & & & & & & & & & & & & & E & \\
\hline III. Evergreen Shrubs & & & & & & & & & & & & E & E & \\
\hline Andromeda polifolia & & & & & & & & & & & & & & \\
\hline Arctostaphylos uva-ursi & & & & & & & & & & & & 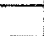 & 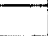 & \\
\hline Castilleja Raupi & & & & & & & & & & & & & & \\
\hline Dryas drummondii & & & & & & & & & & & & 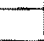 & 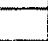 & \\
\hline D. integrifolia & $T$ & & & & & 1 & & & & & & & & \\
\hline Empetrum nigrum & & & & & & & & & & & & & & \\
\hline Juniperus communis & & & & & & & & & & & & & 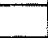 & \\
\hline J. horizontalis & & & & & & & & & & & & & & \\
\hline Ledum spp. & & & & & 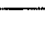 & 1 & & & & & & 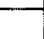 & 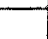 & \\
\hline Linnaea borealis & & & & & & & & & & & & & 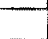 & \\
\hline Vaccinium vitis-idaea & & & & & & & & & 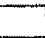 & & & - & 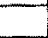 & \\
\hline & & & & & & & & & & & & & - & \\
\hline IV. Annuals & & & & - & & & & & & & & & & \\
\hline Erigeron spp. & & & & & & & & & & & & & & \\
\hline Juncus bufonius & & & & 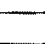 & & & & & & & & & & \\
\hline unspecified Annuals & & & & & & & & & & & & & & \\
\hline & & & & & & & & & & & & & & \\
\hline V. Perennials & & & & & & & & & & & & - & & \\
\hline Achillea nigrescens & & & & & & & & & & & & & & \\
\hline Anemone spp. & & & & & & + & & & 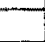 & & & - & & - \\
\hline Arnica alpina & & & & & & & & & & & & & & \\
\hline Artemisia tilesil & & & & & & & & & & & & - & & \\
\hline Aster spp. & + & & & & & & & & & & & 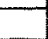 & & \\
\hline Dracocephalum parviflorum & & & & + & & + & & & + & 2 & & + & 2 & 2 \\
\hline Epilobium angustifolium & & 2 & & 2 & 3 & 2 & & 2 & 3 & 4 & & 3 & 3 & $\overline{3}$ \\
\hline E. palustre & & & & & & & & & & & & & & \\
\hline Equisetum arvense & 2 & 2 & & & & & & 2 & 2 & & & & & \\
\hline E. scirpoides & $\begin{array}{l}+ \\
+\end{array}$ & 3 & & + & 1 & 3 & & + & + & + & & & 2 & + \\
\hline E. sylvaticum & & & & & & & & & & & & & & \\
\hline E. variegatum & & & & & & & & & & & & & & \\
\hline
\end{tabular}




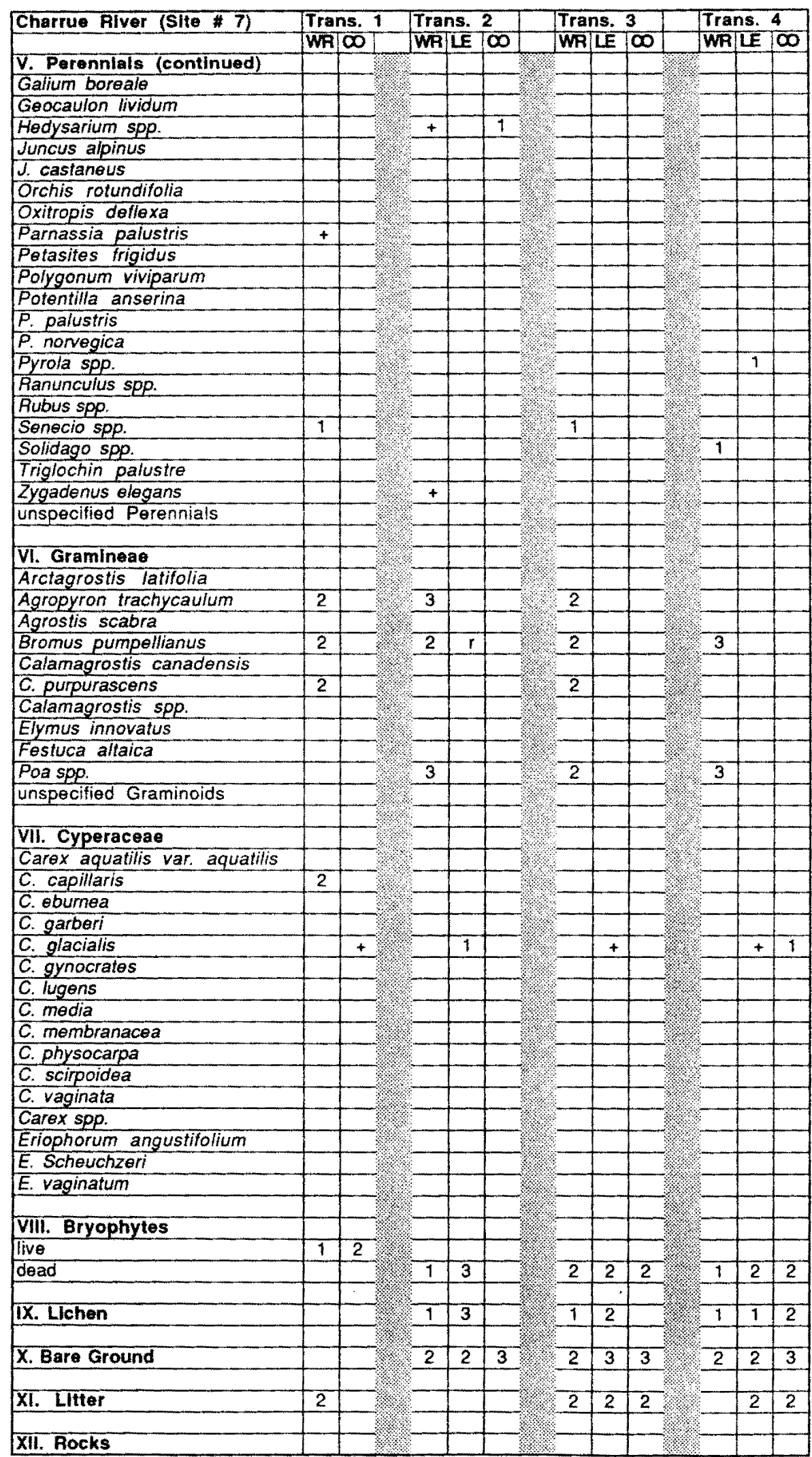




\begin{tabular}{|c|c|c|c|c|c|c|c|c|c|c|c|c|c|c|c|c|c|c|c|}
\hline Mackenzie H'way (Site \# 8) & \begin{tabular}{|l} 
Tra \\
Wh \\
\end{tabular} & Ins. & $\frac{1}{\infty}$ & & rai & & $\frac{2}{\infty}$ & & Trar & & $\begin{array}{l}3 \\
\infty\end{array}$ & & Trar & & 4 & & & & \\
\hline 1. Trees & & & & & & & & & & & & & & & & & & & \\
\hline Betula papyrifera & 2 & 2 & & & & & 1 & & & & & & & & & & 1 & & 1 \\
\hline Larix laricina & 2 & 12 & & & & & & & & & & & & & 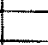 & & & & \\
\hline Picea glauca & & & & & & & & & & & & & & & & & & & \\
\hline Picea mariana & + & 1 & 2 & & & & 2 & & & & 2 & & & $r$ & 3 & & & 2 & 3 \\
\hline Populus balsamifera & & & & & & & & & & & & & & 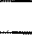 & & & & & \\
\hline P. tremuloides & & & & & & & & & & & & & & & E & & & & \\
\hline & & & & & & & & & & & & & & & & & & & \\
\hline 11. Deciduous Shrubs & & & & & & & & & & & 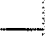 & & & & 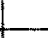 & & & & \\
\hline Alnus crispa & & & 2 & & & & 4 & & & & & & & 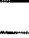 & - & & & & \\
\hline A. incana & & & & & & & & & & & & & & 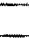 & L & & & & \\
\hline Arctostaphylos alpina & & & & & & & & & & & & & & & & & & & \\
\hline A. rubra & & & & & 3 & & & & & & & & & 2 & 1 & & & & \\
\hline Betula glandulosa & & & & & 1 & & - & & & & & & & 2 & 2 & & 1 & & 1 \\
\hline Conus ssp. & & & & & & & - & & & & & & & & & & & & \\
\hline Potentilla biffora & & & & & & & & & & & & & & 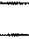 & & & & & \\
\hline P. fruticosa & & & & & & & - & & & & & & & & & & & & \\
\hline P. muitifida & & & & & 1 & & & & & & & & & 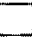 & & & & & \\
\hline Rhododendron lapponicum & & & & & & & & & & & & & & & & & & & \\
\hline Ribes triste & & & & & & & E & & & & E. & & & 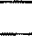 & & & & & \\
\hline Rosa acicularis & 1 & 1 & & & & & - & & & & & & & 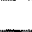 & & & & & \\
\hline Rubus strigosus & & & & & & & & & & & E & & & 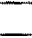 & E & & & & \\
\hline Salix alaxensis & & & & & & & & & & & & & & & & & & & \\
\hline S. arbusculoides & & & & & & & & & & & - & & & & 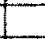 & & & & \\
\hline S. bebbiana & & & & & & & & & & & & & & & & & & & \\
\hline S. glauca & 3 & 2 & 1 & & 1 & 3 & 2 & & & & E & & 2 & - & - & & 2 & & \\
\hline S. lanata & & & & & & & & & & & & & & - & - & & & & \\
\hline S. myrtillifolia & & & & & & & & & & & - & & & & - & & & & \\
\hline S. planitolia & 2 & & & & & & L & & & & - & & & & & & & & - \\
\hline S. pseudomonticola & & & & & & & & & & & 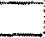 & & & - & & & & & \\
\hline S. pyrifolia & & & & & & & & & & & & & & - & - & & & & \\
\hline Salix spo. & & & & & & & & & 1 & 3 & 2 & & & & 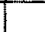 & & 7 & & 1 \\
\hline Sheperdia canadensis & 1 & & 1 & & & & & & & & & & & & - & & & 1 & \\
\hline Vaccinium uliginosum & 1 & 2 & 1 & & 3 & 3 & 2 & & & 2 & 4 & & 3 & 3 & 3 & & & & \\
\hline Viburnum odule & & & & & & & & & & & & & & & & & & & \\
\hline & & & & & & & & & & & & & & $\ldots$ & & & & $\ldots$ & \\
\hline III. Evergreen Shrubs & & & & & & & & & & & & & & & & & & & \\
\hline Andromeda polifolia & & & & & & & & & & & & & & & & & & & \\
\hline Arctostaphylos uva.ursi & & & & & & & & & & & & & & 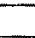 & & & & & \\
\hline Castilleja Raupii & & & & & & & & & & & - & & & 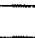 & - & & & & 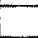 \\
\hline Dryas drummondii & & & & & & & & & & & & & & & & & & & \\
\hline D. integrifolia & & & & & & & & & & & & & 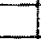 & 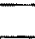 & & & & & \\
\hline Empotrum nigrum & + & 1 & & & & & & & & & & & + & & 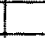 & & & & \\
\hline Juniperus communis & & & & & & & & & & & & & & & & & & & \\
\hline J. horizontalis & & & & & & & & & & & & & & & & & & & \\
\hline Ledum spp. & & 2 & 2 & & + & 2 & 3 & & & & 2 & & & 2 & 1 & & & 2 & 3 \\
\hline Linnaea borealis & & & & & & & & & & & & & & & & & & & \\
\hline Vaccinium vifis-idaea & 1 & 2 & 2 & & & 2 & 2 & & & & 3 & & & 2 & 3 & & 1 & 4 & 3 \\
\hline & & & & & & & & & & & & & & & & & & & \\
\hline IV. Annuals & & & & & & & & & & & & & & & & & & & \\
\hline Erigeron spp. & & & & & & & & & & & & & & 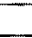 & & & & & \\
\hline Juncus butonius & & & & & & & & & & & & & & & & & & & \\
\hline unspecified Annuals & & & & & & & & & & & & & & ב & & & 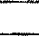 & & \\
\hline & & & & & & & & & & & & & & 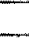 & & & & & \\
\hline V. Perennials & & & & & & & & & & & & & & & & & & & \\
\hline Achillea nigrescens & & & & & & & & & & & & & & 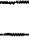 & & & & & \\
\hline Anemone spp. & & & & & & & & & & & & & & & & & & & \\
\hline Arnica alpina & & & & & & & & & & & & & 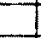 & - & & & & & \\
\hline Artemisia tilesii & & & & & & & & & & & & & & & & & & & \\
\hline Aster spp. & & & & & & & & & & & & & 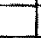 & 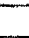 & 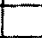 & & 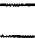 & & \\
\hline Dracocephalum parvifloru & & & & & & & & & & & & & & & & & & & \\
\hline Epllobium angustifolium & & & & & & & & & & & & & & & $\pi$ & & 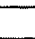 & & \\
\hline E. palustre & + & & & & + & & & & & & & & & & & & + & & \\
\hline Equisetum arvense & & 1 & & & & & & & & & & & & & & & & & \\
\hline E. fluviatile & & & & & & & & & & & & & & & & & & & \\
\hline E. scirpoides & & 1 & 1 & & 1 & 2 & & & & & & & + & 1 & 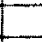 & & 1 & & \\
\hline E. syivaticum & & & & & & & & & & & & & & & & & & & \\
\hline
\end{tabular}




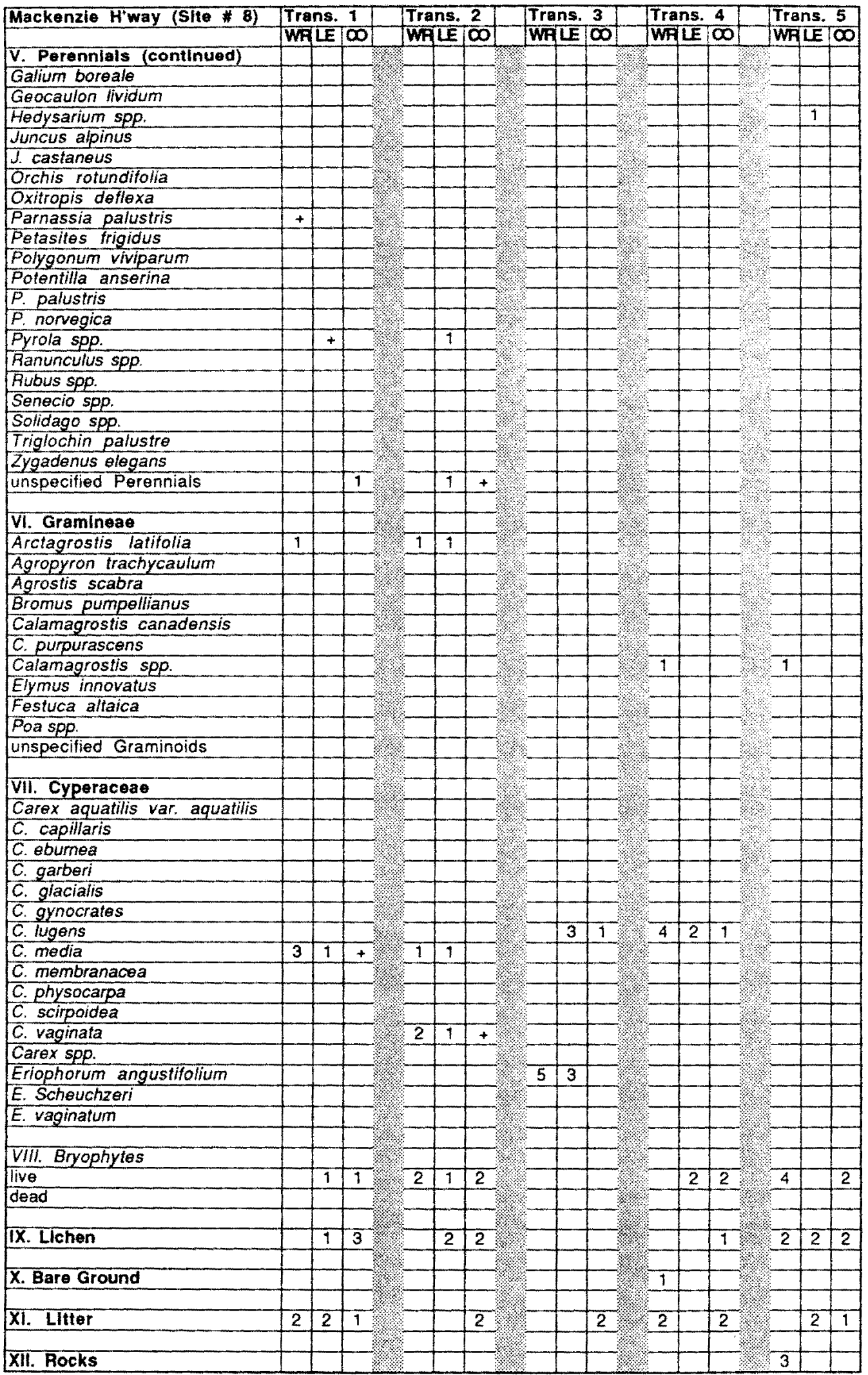




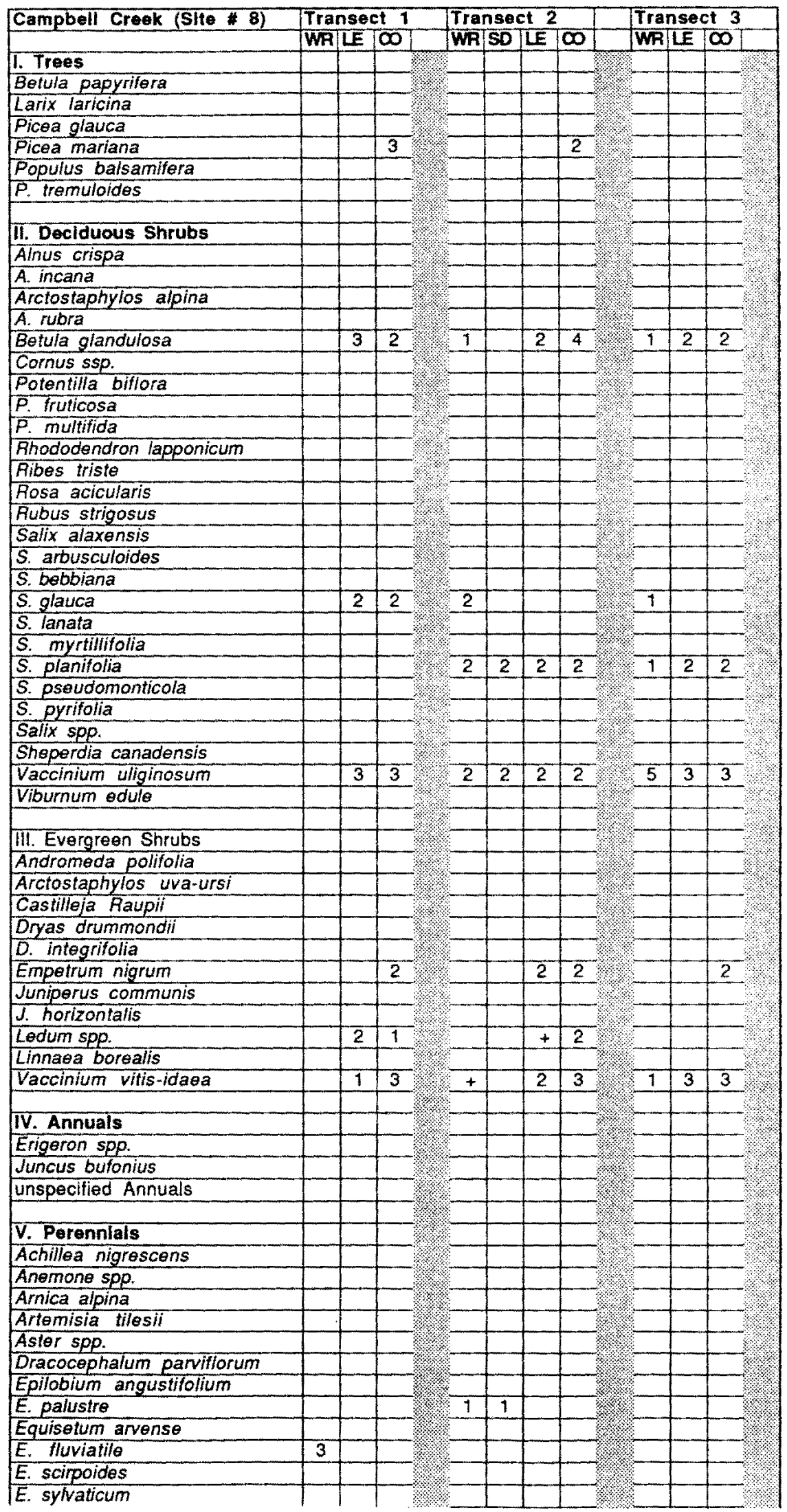




\begin{tabular}{|c|c|c|c|c|c|c|c|c|c|c|c|c|c|}
\hline \multirow{3}{*}{$\begin{array}{l}\text { Campbell Creek (Site } \# \text { 8) } \\
\text { V. Perennials (continued) }\end{array}$} & \multicolumn{3}{|c|}{ Transect 1} & \multicolumn{4}{|c|}{ Transect 2} & & \multicolumn{4}{|c|}{ Transect 3} & \\
\hline & Wh & LE & $\infty$ & |Wa & SD & LE & $\infty$ & & Wh & LE & & क] & \\
\hline & & \\
\hline \multicolumn{13}{|l|}{ Galium boreale } & \\
\hline \multicolumn{13}{|l|}{ Geocaulon lividum } & \\
\hline \multicolumn{13}{|l|}{ Hedysarium spo. } & \\
\hline \multicolumn{12}{|l|}{ Juncus alpinus } & & \\
\hline J. castaneus & & & & & & & & & & & & & \\
\hline Orchis rotundifolia & & & & & & & & & & & & & \\
\hline Oxitropis dellexa & & & & & & & & & & & & & \\
\hline Parnassia palusitris & & & & & & & & & & & & & \\
\hline Petasiles frigidus & & & 1 & + & + & + & 1 & & + & 1 & & $T$ & \\
\hline Polygonum viviparum & & & & & & & & & & & & & \\
\hline Polentilla anserina & & & & & & & & & & & & & \\
\hline$P$ palustris & & & & & & & & & & & & & \\
\hline P. norvegica & & & & & & & & & & & & & \\
\hline Pyrola spp. & & & & & & & + & & & & & & \\
\hline Ranunculus spp. & & & & & & & & & & & & & \\
\hline Rubus spp. & & & & & & & & & & & & & \\
\hline Senecio spp. & & & & & & & & & & & & & \\
\hline Solldago spp. & & & & & & & & & & & & & \\
\hline Triglochin palustre & & & & & & & & & & & & & \\
\hline Zygadenus elegans & & & & & & & & & & & & & \\
\hline Unspecified Perennials & & & & & & & & & & & & & \\
\hline & & & & & & & & & & & & & \\
\hline VI. Gramineae & & & & & & & & & & & & & \\
\hline Arctagrostis latifolia & & 1 & & 1 & + & & 1 & & 1 & & & & \\
\hline Agropyron trachycaulum & & & & & & & & & & & & & \\
\hline Agrostis scabra & & & & & & & & & & & & & \\
\hline Bromus pumpellianus & & & & & & & & & & & & & \\
\hline Calamagrostis canadensis & & & & & & & & & & & & & \\
\hline C. purpurascens & & & & & & & & & & & & & \\
\hline Calamagrostis spp. & & & & & & & & & & & & 1 & \\
\hline Elymus innovatus & & & & & & & & & & & & & \\
\hline Festuca altaica & & & & & & & & & & & & & \\
\hline Poa spo. & & & 1 & 2 & 3 & 1 & 1 & & 2 & 2 & & & \\
\hline Unspecified Graminoids & & & & & & & & & & & & & \\
\hline & & & & & & & & & & & & & \\
\hline VII. Cyperaceae & & & & & & & & & & & & & \\
\hline Carex aquatilis var. aquatilis & 3 & 4 & & & & & & & & & & & \\
\hline C. capillaris & & & & & & & & & & & & & \\
\hline C. eburnea & & & & & & & & & & & & & \\
\hline C. garberi & & & & & & & & & & & & & \\
\hline C. glacialis & & & & & & & & & & & & & \\
\hline C. gynocrates & & & & & & & & & & & & & \\
\hline C. fugens & & & & & & & & & & & & & \\
\hline C. media & & & & & & & & & & & & & \\
\hline C. membranacea & & & & & & & & & & & & & \\
\hline C. physocarpa & & & & & & & & & & & & & \\
\hline C. scirpoidea & & & & & & & & & & & & & \\
\hline C. vaginata & & & & & & & & & & & & & \\
\hline Carex spp. & & & & & & & & & & & & & \\
\hline Eriophorum angustifolium & 3 & & & & & & & & & & & & \\
\hline E. Scheuchzeri & & & & & & & & & & & & & \\
\hline E. vaginatum & & & & & & & & & & & & & \\
\hline & & & & & & & & & & & & & \\
\hline VIII. Bryophytes & & & & & & & & & & & & & \\
\hline live & & 2 & 2 & 1 & 2 & 2 & 2 & & 2 & 2 & & 3 & \\
\hline dead & & & & & & & & & & & & & \\
\hline & & & & & & & & & & & & & \\
\hline IX. LIchen & & 1 & 2 & 1 & & 3 & 1 & & + & 2 & & 1 & \\
\hline & & & & & & & & & & & & & \\
\hline X. Bare Ground & & & & 2 & 2 & & & & 2 & & & & \\
\hline & & & & & & & & & & & & & \\
\hline XI. LItter & & & 1 & 2 & & & 1 & & & \pm & & & \\
\hline & & & & & & & & & & & & & \\
\hline XII. Rocks & & & & & & & & 样 & & & & & \\
\hline
\end{tabular}

